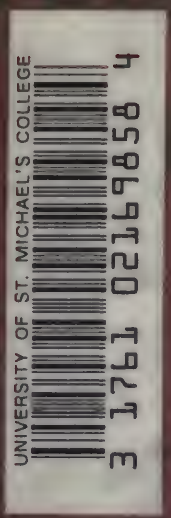

\title{
BY
}

WR EVERETT SHIPIEY 


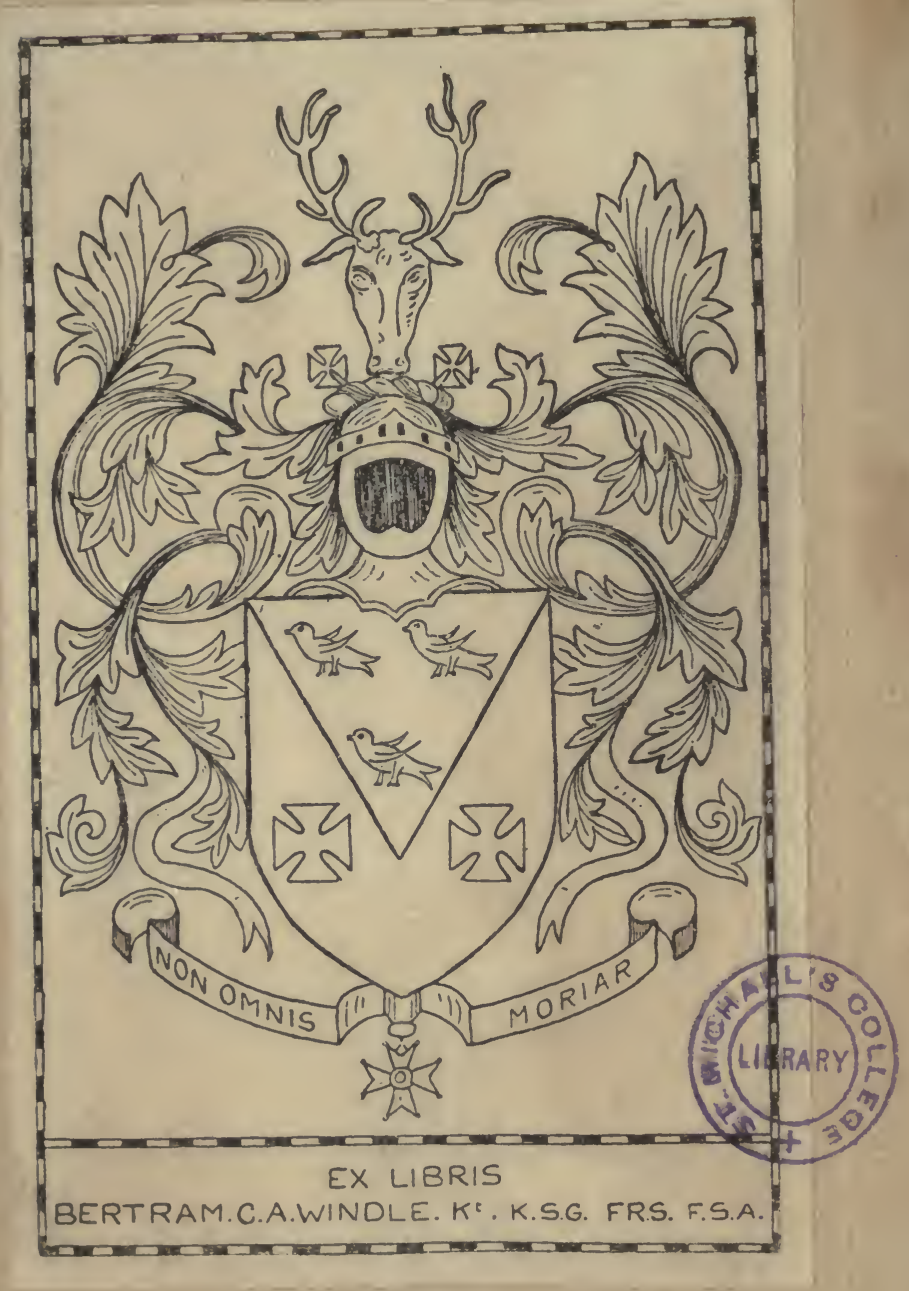


T his Studics in Insect Lifi, (Fisher Unwin), the Master Iof Christ's College, Cambridge, Dr. Shipley, enlivens with unexpected touches of humour a book containing a vast amount of technical information. The bed-bug, for example, would not appear to be a subject either attractive or pleasant, but the writer manages to make it both. The "folding back of the proboscis gives the insect a demure and even a devout expression; it appears to be engaged in prayer, but a bug never prays." It appears that this unpleasant creature, together with the blackbeetle, was introduced into England, with other even more injurious novelties, in the reign of Henry VIII. It can live for a long time without food, and has even been kept incarcerated in a pill-box for a year without succumbing to hunger. When the box was opened the insects were as thin as oiled paper, and so transparent that one could read The Times through them-at any rate, "the larger print, such as the leading articles and letters from admirals." In connection with this matter of insect pests we have had to experience the shattering of a life-long illusion-the monkey is singularly free from fleas, so that another myth has gone to join Alfred and his Cakes and other tales of youth. The chapters on bees contain all the information given by Maeterlinck, here given in much less space and quite as pleasantly. We have always felt that the Humble or Bumble Bee was a more attractive creature than its cousin of the hive ; and Dr. Shipley also finds them " more human and much less exasperating." " The workers work as hard as an Apis, but 



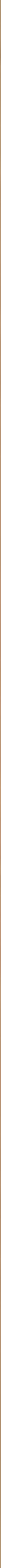


Digitized by the Internet Archive in 2007 with funding from Microsoft Corporation 


\section{STUDIES IN INSECT LIFE}

AND OTHER ESSAYS 




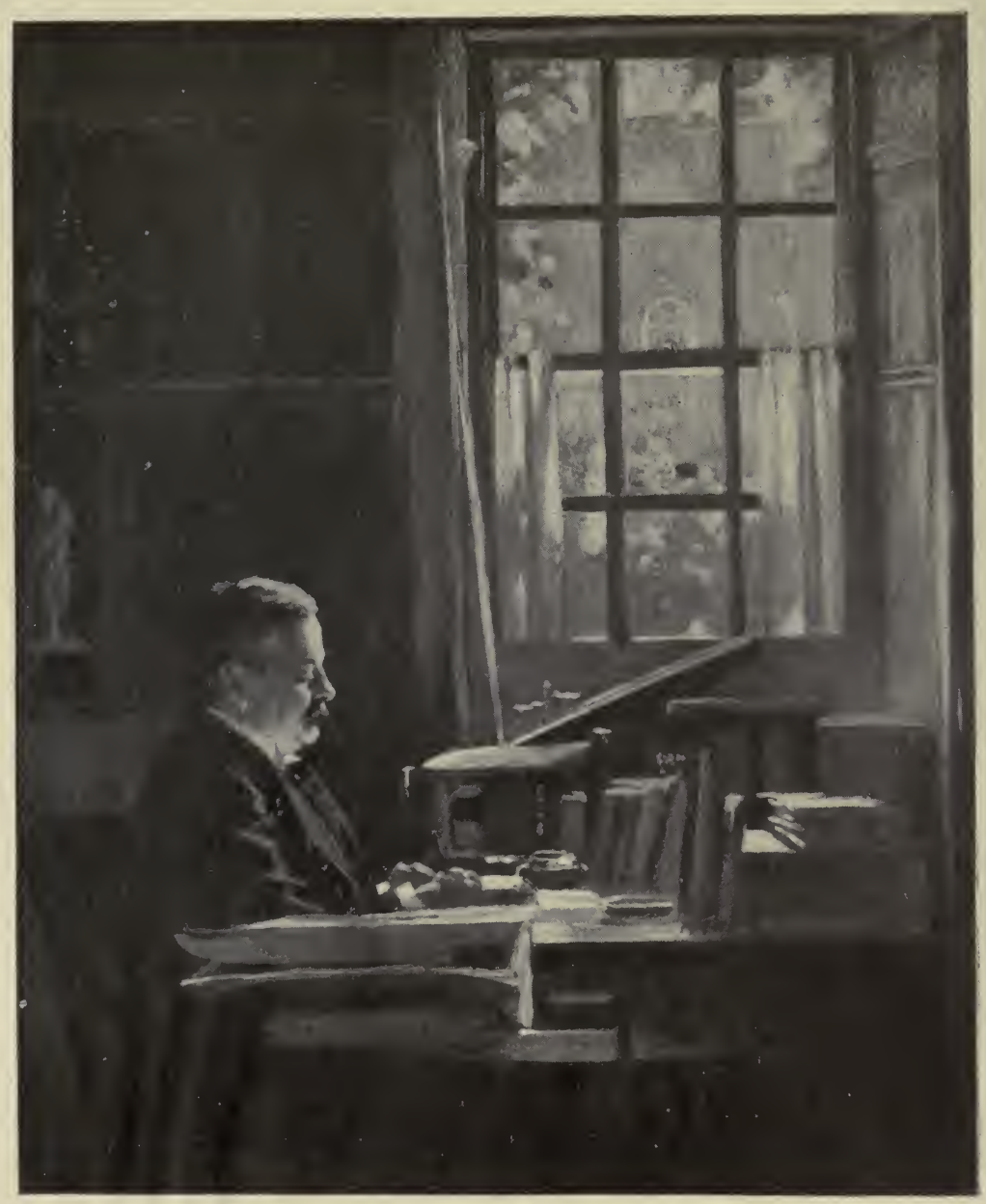

The Author, from a painting by George Henry, A.R.A. 


\section{STUDIES IN INSECT LIFE}

AND OTHER ESSAYS

BY

ARTHUR EVERETT SHIPLEY, Sc.D., F.R.S., Master of Christ's College, Cambridge

WITH ELEVEN ILLUSTRATIONS

T. FISHER UNWIN LTD., ADELPHI TERRACE, LONDON 
First published in 1917

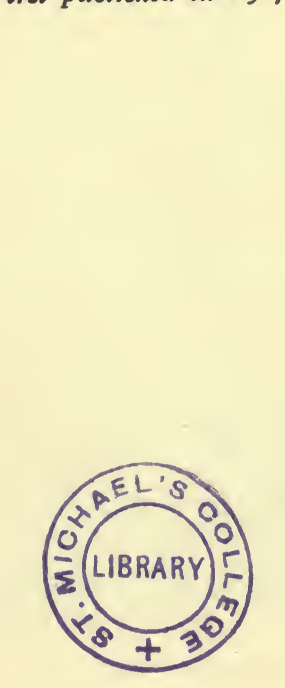

\section{AUG 221957}

[All rights reserved? 
TO

MY BROTHER,

LT.-COLONEL R. B. SHIPLEY, C.M.G., QUEEN VICTORIA'S RIFLES. 


\section{PREFACE}

I AM indebted to the kindness of those responsible for the Edinburgh Review for permission to reprint "The Honey-Bee," "The Romance of the Depths of the Sea," and "Zoology in the time of Shakespeare." I thank the editor and the owner of Country Life who have permitted me to reprint "Bombus, the Humble-Bee," and the article on the "Differences between Wasps and Bees." "Sir John Murray" and the last article of all, "Hate," are reprinted by the kindness of the editor of the Cornhill Magazine. "The Revival of Science in the Seventeenth Century" formed part of the eighth volume of the Cambridge History of English Literature, and the editors of these volumes and the syndics of the Cambridge University Press have willingly given me permission to reprint these pages.

The first essay of all on "Insects and War" was a lecture delivered before the Royal Society of Arts, which subsequently appeared in their viii 
Journal ; "Sea Fisheries" was a Presidential address to The Association of Economic Biologists, and "Grouse Disease" an evening lecture delivered before the Royal Institution. For permission to reprint these I owe my thanks to the authorities of the several institutions named above.

A. E. Shipley.

Christ's College Lodge,

Cambridge.

October, IgI6. 


\section{CONTENTS}

CHAP.

I. INSECTS AND WAR -

II. THE HONEY-BEE - $\quad$ - $\quad$ - $\quad$ - 37

III. BOMBUS, THE HUMBLE-BEE - - - 68

IV. ON CERTAIN DIFFERENCES BETWEEN

WASPS AND BEES - - - _ - 84

V. THE ROMANCE OF THE DEPTHS OF THE

SEA - $\quad$ - $\quad$ - $\quad$ - $\quad$ - $\quad$ - $\quad$ - 90

VI. SEA FISHERIES - $\quad$ - - $\quad$ - $\quad$ - I25

VII. SIR JOHN MURRAY : A GREAT OCEANOGRAPHER - $\quad$ - $\quad$ - $\quad$ - $\quad$ - $\quad$ - I66

VIII. GROUSE DISEASE - _ - - _ - $\quad$ - I8g

IX. ZOOLOGY IN THE TIME OF SHAKESPEARE 222

X. THE REVIVAL OF SCIENCE IN THE SEVENTEENTH CENTURY - - - - 265

XI. HATE - $\quad$ - $\quad$ - $\quad$ - $\quad$ - $\quad-\quad$ - 309 


\section{ILLUSTRATIONS}

Portrait of the Author - - Frontispiece

I. Honey-Bee-A, Drone ; B, Queen; C, Worker - - - - - $\quad 38$

2. Ventral view of a worker bee in the act of removing a wax scale with its left hind leg - $\quad-\quad-\quad-\quad-39$

3. Inner surface of the left hind leg of a worker bee - - - - - 40

4. Cells of Queen Bee - $\quad$ - $\quad$ - $\quad$ - 43

5. Diagram of comb, showing honey-cells above

PAGE 



\section{STUDIES IN INSECT LIFE AND OTHER ESSAYS}

\section{Chapter I \\ INSECTS AND WAR}

"Well, there's nothink lower than Nature, an' She goes as 'igh as 'Eaven."-Emigration Jane.

THE insects which prove such a nuisance to the fighter in time of war are the insects which equally affect man in times of peace. But owing to the different circumstances which arise when men are at war their effects are more concentrated and more persistent. Roughly speaking, we can divide these insect pests into two categories(I) those which pierce the skin of men or of animals on which the soldier is to a great extent dependent, for instance, the horse; and (2) those which interfere with the soldiers' food supplies. The latter, again, fall into two categories-(a) those which materially and 
substantially diminish that food supply, and by leaving their larvæ behind in the diminished stock render the food unpalatable; and $(b)$ those which infect the food supply with pathogenic germs, such as the germs of enteric fever.

Amongst the insects which bite man, or, rather, pierce his skin, and which in times of peace can be kept in some sort of control, is the louse. In times of war, when men are herded together, with little or no opportunity of changing their linen or washing, the louse is sure to appear and it spreads rapidly.

We will confine our attention to the genus Pediculus-P. capitis, the head-louse, and $P$. vestimenti, the body-louse. They do not arise, as the uninformed think, from dirt, though they flourish best in dirty surroundings. No specimen of $P$. vestimenti exists which is not the direct product of an egg laid by a mother-louse and fertilised by a father-louse. In considerable collections of men drawn from the poorer classes, some unhappy being or other-often through no fault of his own-will turn up in the community with lice on him, and these swiftly spread to others.

Like almost all animals lower than the mam- 
mals, the male of the body-louse is smaller and feebler than the female. The former attains a length of about $3 \mathrm{~mm}$., and is about I mm. broad. The female is about $3.3 \mathrm{~mm}$. long and about $\mathrm{I} \cdot 4 \mathrm{~mm}$. broad. It is rather bigger than the hair-louse, and its antennæ are slightly longer. It so far flatters its host as to imitate the colour of the skin upon which it lives; and Andrew Murray gives a series of gradations between the black louse of the West African and Australian native, the dark and smoky louse of the Hindu, the orange of the Africander and of the Hottentot, the yellowish-brown of the North and South American Indians, and the paler brown of the Esquimo, which approaches the light dirty-grey colour of the European parasites :

"As plump an' grey as onie grozet,"

as Burns has it.

The body-louse was the species dealt with in the recent observations undertaken by $\mathrm{Mr}$. C. Warburton in the Quick Laboratory at Cambridge, at the request of the Local Government Board, the authorities of which were anxious to find out whether the flock used in making cheap bedding was instrumental in distributing 


\section{4 STUDIES IN INSECT LIFE, ETC.}

vermin. Mr. Warburton at once appreciated the fact that he must know the life-history of the insect before he could successfully attack the problem put before him. At an early stage of his investigations he found that $P$. vestimenti survives longer under adverse conditions than $P$. capitis, the head-louse.

The habitat of the body-louse is that side of the underclothing which is in contact with the body. The louse, which sucks the blood of its host at least twice a day, is, when feeding, always anchored to the inside of the underclothing of its host by the claws of one or more of its six legs. Free lice are rarely found on the skin in western Europeans. But the underside of a stripped shirt is often alive with them.

After a great many experiments, Mr. Warburton succeeded in rearing these delicate insects, but only under certain circumscribed conditions; one of which was their anchorage in some sort of flannel or cloth, and the second was proximity to the human skin. He anchored his specimens on small pieces of cloth, which he interned in small test-tubes plugged with cotton-wool, which did not let the lice out, but did let the air and the emanations of the human body in. For fear of 
breakage the glass tube was enclosed in an outer metal tube, and the whole was kept both night and day near the body. Two meals a day were necessary to keep the lice alive. When feeding, the pieces of cloth, which the lice would never let go of, were placed on the back of the hand, hence the danger of escape was practically nil, and once given access to the skin the lice fed immediately and greedily.

His success in keeping lice alive was but the final result of many experiments, the majority of which had failed. Lice are very difficult to rear. When you want them to live they die, and when you want them to die they live and multiply exceedingly. A single female but recently matured was placed in a test-tube, and a male admitted to her on the second day. The two paired on the sixth day, and afterwards at frequent intervals. Very soon after pairing an egg was laid, and during the remaining twenty-five days of her life the female laid an average of five eggs every twentyfour hours. The male died on the seventeenth day, and a second male was then introduced, who again paired with the female. The latter, however, died on the thirtieth day, but the second male survived. 
The difficulty of keeping the male and female alive was simple compared with the difficulty of rearing the eggs. Very few hatched out. The strands of cloth upon which they were laid had been carefully removed and placed in separate tubes, at the same time being subjected to different temperatures. It was not, however, until the eggs were left alone undisturbed in the position where they had been laid and placed under the same conditions that the mother lived in, that eight and only eight, of the twenty-four eggs laid on the cloth hatched out after an incubation period of eight days. The remaining sixteen eggs were apparently dead. But the tube in which they were was then subjected to the normal temperature of the room at night (on occasions this fell below freezing-point), and after an incubation period of upwards of a month six more hatched out. Hence it is obvious that, as in the case of many other insects, temperature plays a large part in the rate of development, and it becomes clear that the eggs or nits of $P$. vestimenti are capable of hatching out up to a period of at least from thirty-five to forty days after they are laid.

Difficult as it was to keep the adults alive, and 
more difficult as it was to hatch out the eggs, it was most difficult to rear the larvæ. Their small size made them difficult to observe, and, like most young animals, they are intolerant of control, apt to wander and explore, and less given to clinging to the cloth than their more sedentary parents. Naturally, they want to scatter, spread themselves, and pair.

Like young chickens, the larvæ feed immediately on emerging from the egg. They apparently moult three times, at intervals of about four days, and on the eleventh day attain their mature form, though they do not pair until four or five days later.

Mr. Warburton summarises the life-cycle of the insects, as indicated by his experiments, as follows: Incubation period, eight days to five weeks ; from larva to imago, eleven days; nonfunctional mature condition, four days; adult life-male, three weeks; female, four weeks.

But we must not forget that these figures are based upon laboratory experiments, and that under the normal conditions the rate may be accelerated. From Mr. Warburton's experience it is perfectly obvious that, unless regularly fed, body-lice very quickly die. Of all the verminous 
clothing sent to the Quick Laboratory, very little contained live vermin. The newly-hatched larvæ perish in a day and a half unless they can obtain food. These facts regarding the life-history of body-lice were fully confirmed by Dr. Fantham when working on the protozoal parasites of lice.

With regard to the head-louse :

"Ye ugly, creepin', blastit wonner, Detested, shunn'd by saunt an' sinner,"

it is smaller than the body-louse, and is of a cindery-grey colour. The female measures $I .8 \mathrm{~mm}$. in length and $0.7 \mathrm{~mm}$. in breadth. Like the body-louse, it varies its colour somewhat with the colour of the hair on the different branches of the human race. It lives amongst the hair of the head of people who neglect their heads; it is also, but more rarely, found amongst the eyelashes and in the beard. The egg, which has a certain beauty of symmetry, is cemented to the hair, and at the end of six days the larvæ emerge, which, after a certain number of moults, become mature on the eighteenth day. The methods adopted by many natives of plastering their hair with coloured clay, or of anointing it with ointments, probably guards against the presence of these parasites. The Spartan youths, 
who used to oil their long locks before going into battle, may have feared this parasite. Some German soldiers, before going to war, shave their heads; thus they afford no nidus for $P$. capitis. The wigs worn in the late seventeenth and at the beginning of the eighteenth centuries undoubtedly owed something to the difficulty of keeping this particular kind of vermin down. The later powdering of the hair may have been due to the same cause.

$P$. capitis is in war-time less important than $P$. vestimenti. The former certainly causes a certain skin trouble, but the latter not only affords constant irritation, but, like most biting insects, from time to time conveys most serious diseases. $P$. vestimenti is known to be the carrier of typhus. This was, I believe, first demonstrated in Algeria, but was amply confirmed two years ago in Ireland, when a serious outbreak of this fever took place, though little was heard of it in England. Possibly, $P$. capitis also conveys typhus, but undoubtedly both convey Spirochaeta recurrentis - the cause of relapsing or recurrent fever.

The irritation due to the body-louse weakens the host and prevents sleep; besides there 
is a certain psychic disgust which causes many officers to fear lice more than they fear bullets. Also by rubbing or scratching the lice may be crushed on the skin. The germs of disease within them may thus be inoculated directly into the blood through the surface of the skin damaged by the scratch. Soldiers should, further, always avoid touching their eyes after scratching insectbites. Lice are the constant accompaniment of all armies; and in the South African War as soon as a regiment halted they stripped to the skin, turned their clothes inside out and picked the Anoplura off. As a private said to me: "We strips and we picks 'em off and puts 'em in the sun, and it kind o' breaks the little beggars' 'earts!"

There were serious outbreaks of typhus during the recent and present Balkan wars among the combatants, prisoners, and refugees. These epidemics were spread by lice. Again, typhus and relapsing fever are endemic in various areas along the eastern front of the present theatre of war, and these diseases have devastated stricken Serbia.

Another insect which pierces the skin of man and destroys the continuity of his integument is the bed-bug, Cimex lectularius. 
The common bed-bug seems to have arrived in England about the same time as the cockroach, that is, over four hundred years ago, early in King Henry VIII.'s reign. Apparently it came from the East, and was for many years confined to seaports and harbours. It seems to have been first mentioned by playwriters towards the beginning of the seventeenth century. The sixteenth-century dramatists could never have resisted mentioning the bug had it been in their time a common household pest. It would have appealed to their sense of humour.

How the insect got the name of "bug" is unknown. It has been suggested that the Old English word "bug," meaning a ghost or phantom which walked by night, has been transferred to Cimex. This may be so, but the "Oxford English Dictionary" tells us that proof is lacking.

The insect is some $5 \mathrm{~mm}$. in length, and about $3 \mathrm{~mm}$. in breadth, and is of a reddish- or brownishrusty colour, fading into black. Its body is extraordinarily flattened, so that it can readily pass into chinks or between splits in furniture and boarding, and this it does whenever daylight appears, for the bug loves darkness rather than light because its deeds are evil. The head 
is large, and ends in a long, piercing, four-jointed proboscis, which forms a tube with four piercing stylets in it. As a rule, the proboscis is folded back into a groove, which reaches to the first pair of legs on the under surface of the thorax. This folding back of the proboscis gives the insect a demure and even a devout expression; it appears to be engaged in prayer, but a bug never prays. The head bears two black eyes and two four-jointed antennæ. Each of the six legs is provided with two claws, and all the body is covered with fairly numerous hairs. The abdomen shows seven visible segments and a terminal piece.

The bug has no fixed period of the year for breeding; as long as the temperature is favourable and the food abundant generation will succeed generation without pause. Should, however, the weather turn cold the insects become numbed and their vitality and power of reproduction are interrupted until a sufficient degree of warmth returns.

Like the cockroach, the bed-bug is a frequenter of human habitations, but only of such as have reached a certain stage of comfort. It is said to be comparatively rare in the homes of savages ; 
but it is only too common in the poorer quarters of our great cities. The iron bedstead which has so rapidly replaced the wooden bedstead was at one time thought to render the bug's position untenable-a belief much cherished by the manufacturers of metal bedsteads. But this is not so. Bugs will shelter in its metallic crevices almost as comfortably as in the wooden chinks of its predecessor. Its presence does not necessarily indicate neglect or want of cleanliness. It is apt to get into trunks and luggage, and in this way may be conveyed even into the bestkept homes. It is also very migratory, and will pass readily from one house to another, and when an infested dwelling is vacated these insects usually leave it for better company and better quarters. Their food supply being withdrawn, they make their way along gutters, water-pipes, etc., into adjoining and inhabited houses. Cimex is particularly common in ships, especially emigrant ships, and, although unknown to the aboriginal Indians of North America, it probably entered that continent with the "best families" in the "Mayflower."

Perhaps the most disagreeable feature of the bed-bug is that it produces an oily fluid which 
has a quite intolerable odour; the glands secreting this fluid are situated in various parts of the body. The presence of such glands in free-living Hemipterous insects is undoubtedly a protection -birds do not as a rule touch them. One, however, fails to see the use of this property in the bedbug. At any rate, it does not deter cockroaches and ants, as well as other insects, from devouring the Cimex. There is a small black ant in Portugal which is said to clear a house of these pests in a few days; but one cannot always command the services of a small black Portuguese ant.

Another remarkable feature is that the insect has no wings, although in all probability its ancestors possessed these useful appendages. As the American poet writes :

"The Lightning-bug has wings of gold, The June-bug wings of flame, The Bed-bug has no wings at all, But he gets there all the same!"

The power of "getting there" is truly remarkable. Man, their chief victim, has always warred against bugs, yet, like the poor, bugs " are always with us." I heard it stated, when I was living in Southern Italy, that if you submerged the legs of your bed in metal saucers full of water 
and placed the bed in the centre of the room, the bugs will crawl up the wall, walk along the ceiling and drop on to the bed and on to you. Anyhow, whether this be so or not, there is no doubt that these insects have a certain success in the struggle for life, and only the most systematic and rigorous measures are capable of ridding a dwelling of their presence.

The eggs of the bed-bug are pearly white, oval objects, perhaps I mm. in length. At one end there is a small cap surrounded by a projecting rim, and it is by pushing off this cap, and through the orifice thus opened, that the young bug makes its way into the outer world after an incubation period of a week or ten days. There is no metamorphosis-no caterpillar and no chrysalis stages. The young hatch out miniatures in structure of their parents, but in colour they are yellowish-white and nearly transparent. The young feed readily, and feeding takes place between each moult and the moults are five in number, before the adult imago emerges. This it does about the eleventh or twelfth week after hatching. These timelimits depend, however, upon the temperature after hatching, and the rate of growth depends 
not only upon the temperature, but also upon the amount of food.

When bred artificially, and under good conditions, the rate of progress can be "speeded up" so that the eggs hatch out in eight days, and every following moult takes place at intervals of eight days, so that the period from egg to adult can be run through in as short a time as seven weeks. Unless fed after each moult, the following moult is indefinitely postponed. Hence it follows that in the preliminary stages bugs must bite their hosts five times before the adult form emerges, and the adult must, further, have a meal before she lays her eggs. The eggs are deposited in batches of from five to fifty in cracks and crevices, into which the insects have retired for concealment.

Bugs can, however, live a long time without a meal. Cases are recorded in which they have been kept alive for more than a year incarcerated in a pill-box. When the pill-box was ultimately opened, the bugs appeared to be as thin as oiled paper, and so transparent that you could read The Times* through them; but even under

* Only the larger print, such as the leading articles and letters from admirals. 
these starvation conditions they had managed to produce offspring. De Geer kept several alive in a sealed bottle for more than a year. This power of existing without food may explain the fact that vacated houses occasionally swarm with bugs even when there have been no human beings in the neighbourhood for many months.

The effect of their bite varies in different people. As a rule, the actual bite lasts for two or three minutes before the insect is gorged, and at first it is painless. But very soon the bitten area begins to swell and to become red, and at times a regular eruption ensues. The irritation may be allayed by washing with menthol or ammonia.

The bed-bug has been accused of conveying many diseases. How far it does this in nature seems uncertain. But it certainly contains certain pathogenic spirochaetes, and monkeys have been infected in the laboratory with these.

In India the bed-bug is under suspicion of spreading kala-azar, or "black fever." Other insects probably convey similar diseases in various parts of the tropics and sub-tropics, as is indicated by the recent experiments of Professor Laveran and Dr. Franchini in Paris, 
and Drs. Fantham and Porter in Cambridge. Whether bugs be guilty of these crimes or not, they are the cause of an intense inconvenience and disgust, and should, if possible, be dealt with drastically. At the present time there are rumours that some of our largest home camps are infested with these insects, and there seems no doubt that some of the prisoners and refugees to this country have brought their fauna with them, and this fauna is very capable of spreading in concentration camps. The erection of wooden huts-no doubt a pressing necessity-affords convenient quarters for these pests.

A third biting insect is the flea.

Fleas are temporarily parasitic on many mammals and birds, but some mammals and some birds are much freer from fleas than others. As the flea is only on its host for part of the time, it has to put in the remainder in some other place, and this, in the case of the human flea, is as a rule the floor, and in the case of birdfleas the birds' nests; from these habitats they can easily regain their hosts when the latter retire to rest. But numbers of Ungulatesdeer, cattle (except when domesticated), ante- 
lopes, goats, wild boars-usually sleep in different places each recurrent night, and to this is probably due the fact that, with the exception of two rare species-one taken in Northern China and the other in Transcaucasia-the Ungulates have furnished descriptive science with no fleas at all. Both of these Ungulate fleas are allied to the burrowing-fleas, or " chigoes."

I know none of my readers will believe me when I write that the same is true of monkeys; but I do this on the undoubted authority of Mr. Harold Russell, who has recently published a charming little monograph on these lively little creatures. Monkeys in nature are cleanly in their habits; and although in confinement occasionally a human flea attacks them, and although a chigoe bores sometimes into the toes of a gorilla or chimpanzee, "speaking generally, it may be said that no fleas have been found truly parasitic on monkeys." Whatever the monkeys are looking for, it is not the fleas. What they seek is, in effect, little scabs of scurf, which are made palatable to their taste by a certain sour sweat.

As a rule, each host has its own species of flea, but though, for the most part, Pulex irritans is 
confined to man it is occasionally found on cats and dogs, whilst, conversely, the cat and dog fleas (Ctenocephalus felis and Ct. canis) from time to time attack man.

The bite of the flea is accompanied by the injection of the secretions of the so-called salivary glands of the insect, and this secretion retards the coagulation of the victim's blood, stimulates the blood-flow, and sets up the irritation we have all-or nearly all-felt.

It is only a few years ago that the spread of bubonic-plague was associated first with rats, and then with rat-fleas; and at once it became of enormous importance to know which of the numerous species of rat-fleas would attack human beings. The Hon. Charles Rothschild, who has accumulated a most splendid collection of preserved fleas in the museum at Tring, had some years ago differentiated from an undifferentiated assemblage of fleas a species first collected in Egypt, but now known to be the commonest rat-flea in all tropical and subtropical countries. This species, Xenopsylla cheopis-and to a lesser extent Ceratophyllus fasciatus-unfortunately infests and bites man. If they should have fed upon a plague-infected 
rat and subsequently bite man, their bites communicate bubonic plague to human beings. Plague-the Old English "Black Death"-is a real peril in our armies now operating in Asia and in certain parts of Africa.

Just as some fleas attack one species of mammal or bird and avoid closely-allied species, so the human flea has its favourites and its aversions. There is a Turkish proverb which says, "An Englishman will burn a bed to catch a flea," and those who suffer severely from fleabites would certainly do so. The courage of the Turk in facing the flea, and even worse dangers, may be, as the schoolboy wrote, "explained by the fact that a man with more than one wife is more willing to face death than if he had only one." But there are persons even a flea will not bite. Mr. Russell has reminded us, in his preface, of the distinguished lady who remarked, "Quant a moi ce n'est pas la morsure, c'est la promenade!"

There are one or two structural features in a flea which are peculiar, the most remarkable being that, unlike most other insects, it is much taller than it is broad. As a rule, insects-such as a cockroach, the bed-bug, or a stag-beetle- 
are like skates, broader than they are tall; but the flea has a laterally compressed shape, like a mackerel or a herring. Then, again, the three segments or rings which come after the head are not fused into a solid cuirass or thorax as they are in the fly or the bee, but they are movable one on the other. Finally, it is usual in insects for the first joint of the leg to be pressed up against and fused with those segments of the body that bear them, but in the flea, not only is this joint quite free, but the body segment gives off a projection which stretches out to bear the leg. Thus the leg seems, unless carefully studied, to have an extra joint and to be-as, indeed, it is-of unusual length. They certainly possess unusual powers of jumping-as Gascoigne, a sixteenth-century poet (I540-78) writes: "The hungry fleas which frisk so fresh."

The male, as is so often the case amongst the invertebrata, is much smaller than the female. The latter lays at a time from one to five minute, sticky, white eggs, one-fortieth of an inch long by one-sixtieth broad. They are not laid on the host, but in crevices between boards, on the floor, between cracks in the wainscoting, or at the bottom of a dog-kennel or in birds'-nests. 
Mr. Butler recalls the case of a gentleman who collected on four successive mornings sixty-two, seventy-eight, sixty-seven, and seventy-seven catfleas' eggs from the cloth his cat had slept upon, altogether 284 eggs in four nights.

The date of hatching varies very much with the temperature. Pulex irritans takes half as long again-six weeks instead of four-to become an adult imago in winter as it does in summer. But in India the dog-flea will complete its cycle in a fortnight.

When it does emerge from the egg the larva is seen to be a whitish segmented little grub without any limbs, but with plenty of bristles which help it to move about and this it does very actively. There are two small antennæ and a pair of powerful jaws, for the larva does not take liquid food, but eats any scraps of solid organic matter which it comes across; dead flies and gnats are readily devoured. The larva casts its skin several times, though exactly how often it moults seems still uncertain.

After about twelve days of larval existence it spins itself a little cocoon in some sheltered crevice, and turns into a whitish inert chrysalis or pupa. During its pupal existence it takes, 
of course, no food, but it grows gradually darker, and after undergoing a tremendous internal change, breaking down its old tissues and building up new ones, the chrysalis-case cracks and the adult flea jumps out into the world.

Perhaps the most important of biting insects is the mosquito, certain species of which carry the microscopic organism which causes malariaa disease which has probably played a greater part in the history of the world than that conveyed by any other insect. As in most other biting insects, the piercing organ consists of two tubes, or gutters, in the hollow of which lie certain chitinous rods, with saw-like edges. The outer gutter encloses an inner gutter facing the other way, between these two tubes the blood the mosquito sucks will ultimately flow. In the mosquito there is also a median structure, like a doubleedged sword, the prolongation of the lower lip. This is traversed by the duct through which flows the so-called saliva of the insect. This saliva carries with it the microscopic, unicellular animals which cause malaria, and down this minute, microscopic duct has flowed the fluid which has altered the fate of continents and 
played a conspicuous part in the destruction of the ancient civilisations of Greece and Rome.

The female is very voracious, but the mouth parts of the male are not strong enough to penetrate the human skin; the male has to be content with a diet of vegetable juice. But the female will suck up blood till all the cracks between its chitinous armour are incarnadined. It is thought by some that no eggs are laid unless a meal of blood has been taken. This, however, does not seem to have been definitely established.

Anopheles maculipennis is the chief carrier of malaria, and is found very widely distributed throughout the world. As a rule individuals do not wander very far on their own account but they can be blown considerable distances by a wind, and they have a habit of travelling about in trains and ships, but not, perhaps, to the same extent as Stegomyia calopus, which conveys the yellow-fever. The female hibernates throughout the winter, and is common under the frozen snows of Siberia, mingled with the moss and snow. In England they are frequently found in old out-houses, deserted cellars, and unused farm buildings. They have generally left their winter quarters by May, when they begin to lay 
their eggs, and this they do early in the morning. In temperate climates there are three or four generations during the summer, the latest being through September and October. It has been calculated that if the number of eggs laid by the female be 50 , the number of the descendants by the fourth generation would amount to over thirty million. This may account for the enormous numbers in which mosquitos are found in places like Finland, Siberia, and other northern climates.

The eggs are rather like little lifeboats, with a float on each side which keeps the ova the right way up. They are black with a certain iridescence, and, like all other objects floating on the surface, they tend to form star-like or reticulated patterns, and if they are near where the water touches the edge of the vessel they are drawn a little way up. But the head-end of the egg always points downwards, so that should the larva emerge whilst in this position it at once gets into its proper element. The larva emerges during the second or third day after oviposition, according to the temperature. It is one of the most interesting aquatic larvæ we know. It hangs on the lower surface of the surface-film by a 
series of palmate hairs; and by its open stigmata or breathing pores, which pierce the surface-film, it puts the interior of the body in connection with the atmosphere. The head is provided on its under surface with two moustache-like structures, which constantly sweep the under surface of the surface-film, sweeping the organic matter which may have floated up from below into the larva's mouth. Since the dorsal surface of the larva is uppermost, and the brushes are on the under surface of the head, when feeding the head is turned round at an angle of $I 90^{\circ}$, and this is done with so much precision that you can almost hear it click. The pupa is also attached to the surface-film by its breathing trumpets, and it is these stigmata, or breathing pores, that are the weak point in the structure of these Diptera, since it is easy by brushing paraffin through the water to establish a thin surface-film of oil, which cuts both larva and pupa off from the necessary oxygen, and so kills them.

Stegomyia, the carrier of yellow-fever, is somewhat different in appearance. It is especially a haunter of the dwellings of man, and it frequents ships. Its eggs are covered with a series of reticulations containing air which enables 
them to float, and the larvæ, unlike those of Anopheles, but like those of Culex, hang down into the water by single respiratory tubes.

They seem to bite all the twenty-four hours round, and although we have not been able to isolate the organisms which cause yellow-fever, there is no doubt the fever is conveyed by this species of mosquito.

There are also a number of biting flies, such as the Tsetse fly, which suck blood greedily, and the blood-sucking maggot of a fly, a larva of Auchmeromyia luteola, which chiefly affects natives sleeping on mats in Central and subtropical Africa, and there are, of course, many flies which injure horses and cattle, and materially diminish the value of their hides. Leather plays a very conspicuous part in warfare. The deterioration of hides owing to the warble fly very materially affects the leather market, not to mention the fact that when cattle are attacked the meat is also seriously damaged.

Let us turn now for a few minutes to the insects that affect the food of man. Both the housefly and the blue-bottle fly act in this manner. 
In our country house-flies usually begin to breed in June and July, continuing well on into October if the weather be but warm. Their greatest activity is, however, in the hotter month of August and the beginning of September. But in warm stables, restaurants, and kitchens, flies are able to reproduce the whole year round. A single fly will deposit at one time roo to $\mathrm{I}_{50}$ eggs, and in the course of her summer life may produce five, or even six, batches of ova each of this size. The eggs are pearly-white, elongated structures, with two converging lines, along which the egg-case will ultimately split to give exit to the larva. The eggs are laid a little way beneath the surface of a dung-heap, by means of a long ovipositor, in a position where they will not readily be dried up. In favourable conditions the eggs hatch in from eight to twentyfour hours.

The larvæ are legless, tapering towards the head, which bears a pair of breathing-holes, or spiracles; their bodies are much stouter towards the hinder end. On the whole they are white, unpleasant-looking maggots, called by freshwater fishermen "gentles." By contracting and expanding their bodies they push their way 


\section{STUDIES IN INSECT LIFE, ETC.}

through the moist, semi-liquid surroundings. The skin is usually moulted some twenty-four hours after birth, but all these time-limits depend much upon the temperature and favourable conditions. With normally high temperatures-say, with $86^{\circ}$ to $95^{\circ} \mathrm{F}$.- the larva will become fully grown in five or six days. The third and final stage, after the second moult or ecdysis, lasts three days, and when fully grown the maggots are about half an inch in length. Externally, twelve segments are visible, but the internal anatomy shows that thirteen are really present, though one is almost "masked."

It is only during these larval stages that the insect grows, and it is never more bulky than in the third larval stage. Now it leaves the moist situation in which it has flourished, and, crawling through the manure, seeks some dry or sheltered corner near the surface of the manure heap. For a time it rests, and then after an hour or two's quiescence it retracts its anterior end and assumes a barrel-shaped outline, its creamy white colour slowly changing to a mahogany brown. The larval skin forms the pupacase, and within this pupa-case the body of the larva undergoes a wonderful change, far 
greater than ever human beings undergo at the time of puberty. Many of its organs are disintegrated and re-formed, and in the course of three or four days the white, legless, repellent maggot, who "loves darkness rather than light," is changed into the lively, flying insect, seeking " a place in the sun" and the companionship of man. As the Frenchman said of the pig which goes into one end of the machine in the Chicago meat-factory as live pig and comes out at the other end in the form of sausages, "Il est diablement change en route."

In a very short time after leaving the pupacase the adult fly has stretched her wings, the chitin of her body has hardened, and she flies away "on her several occasions."

Flies become sexually mature in a week or ten days after emerging from the chrysalis-case, and are capable of depositing their eggs four days after mating, so that if the conditions be indeed favourable the whole development from the egg to the perfect fly may be accomplished in nine or ten days, and the second generations are able to lay their eggs ten days later. The appalling fecundity of such an insect explains the fact that in the hotter parts of the world 
nearly every edible thing seems to be covered with_flies.

The proboscis of a fly can only suck up liquid food; and when we see it feeding on solid substances, such as sugar, it has really dissolved the sugar by depositing some saliva on it, and is sucking up the sugary solution so produced. It not infrequently regurgitates its food in a spherical drop, which it generally reabsorbs.

As we have seen, flies are very susceptible to temperature, and with the approach of cold weather they seem to die. We used to think that some, in a state of suspended animation, "carried on" through the winter months. This is, however, "non-proven." Many of them undoubtedly die in the autumn, as bees die, of old age. They are literally worn out. But a great number fall victims to a parasitic fungus called Empusa. Flies killed by this fungus are frequently to be seen in autumn, hanging dead on windows, etc., surrounded by a little whitish, powdery ring of spores formed by the fungus.

Flies, like many other common insects, are extremely difficult to keep alive in captivity, and few have succeeded in rearing them for more than a month or two. At one time, as 
we have said, it was thought that those flies which survive the winter were fertilised females of the younger broods, and that during the winter they subsisted on their "fat bodies," and it may be so.

Flies breeding in horse manure, or coming direct from infected organic matter, contaminate the jam, the milk, and other food of the soldier. Until the perfecting of the anti-typhus inoculation was effected, in times of war typhoid killed more soldiers than bullets. Infantile diarrhœa is another disease associated with Musca domestica, ophthalmia and anthrax are others.

It will be noted that the fly acts simply as an inoculating agent. The germs which are conveyed are mostly bacteria, and they do not necessarily undergo any change within the body of the house-fly.

Next we come to a series of insects which affect the food of soldiers and sailors. One is the flour-moth, Ephestia kuhniella, whose larva burrows through the soldiers' biscuit and not only consumes a considerable portion of it, but renders it so unpalatable that Sergeant Daniel Nicol, of the 92nd Gordon Highlanders, tells us that, during the Expedition to Egypt in I8or, 
"some vessels were despatched to Macri Bay for bullocks, and others to Smyrna and Aleppo for bread, which was furnished us by the Turks - a kind of hard dry husk. We were glad to get this, as we were then put on full rations, and our biscuits were bad and full of worms; many of our men could only eat them in the dark."

The biscuits become infected during the cooling which takes place between the baking and the packing. The adult insect, E. kuhniella, is a perfect nuisance in flour-mills. So persistent and so numerous are these moths at times that they clog the rollers with their cocoons, and sometimes completely stop them. The webbing of the elevators in the mills often becomes covered with them and with their silky skeins, and then the elevators stop working. They mat together the flour and meal with their silken excreta, and so uniform is the temperature of the Mill, and so favourable to the life of the insect, that they complete their life-cycle in this country in two months, and in the warmer parts of America even more rapidly. In well-heated Mills the proceeding is continuous, so that six generations at least may be produced each year.

Now that the war is spreading in the Near 
East, a word or two should also be said about an allied species of insect, Ephestia cautella, which infests at times 50 per cent. of the figs of the East. It is a moth which is spread all over the world, and is catholic in its taste, since it flourishes on rice, bran, dried apples, maize, and a great many more or less nutritious foods. In Asia Minor it lays its eggs in the figs whilst they are being dried in the sun. From the egg a small maggot emerges and whoever eats dried figs must at times come across them. These larvæ, which emerge when September melts into October, render a voyage on a fig-laden ship very unpleasant, as they crawl about the ship before pupating.

Finally, we must not forget the biscuit "weevil," so familiar to us in Marryat's novels. And the first thing to notice about it is that it is not a weevil at all. It is in truth known as Anobium paniceum, and is closely allied to $A$. striatum, which makes the little round holes in worm-eaten furniture so cleverly imitated by second-hand furniture dealers. There is hardly anything the larva of this insect will not eat, from cayenne pepper to opium, from tablets of compressed meat to Arabic manuscripts. It is, 


\section{STUDIES IN INSECT LIFE, ETC.}

however, to-day, far less common than in the past through the invention of the biscuit-tin, a comparatively modern discovery, which has done much to interfere with its plans. 


\section{Chapter II \\ THE HONEY-BEE I sing, Maecenas, and I sing to thee I"}

"The birth and genius of the frugal bee,

THE social life of the honey-bee (Apis mellifica) is more complex than that of any other animal save man, and in some respects the differentiation of the units which compose the society surpasses anything we can recognise in human economy. Among other bees and wasps the future of the race is wrapped up throughout the winter months in the body of one fertilised female; should she die, the particular race is at an end; but the honey-bee colony lives through the winter and is permanent, or at any rate potentially permanent. Although a "queen" is cherished, the life of the hive is socialistic. No private property exists; " all is the State's; the State provides for all." In devotion to duty, in single-mindedness of purpose, in energy expended for others, in whole- 
hearted devotion to the welfare of the community which shelters her, the worker-bee is unique.

As every one knows, the inhabitants of a hive
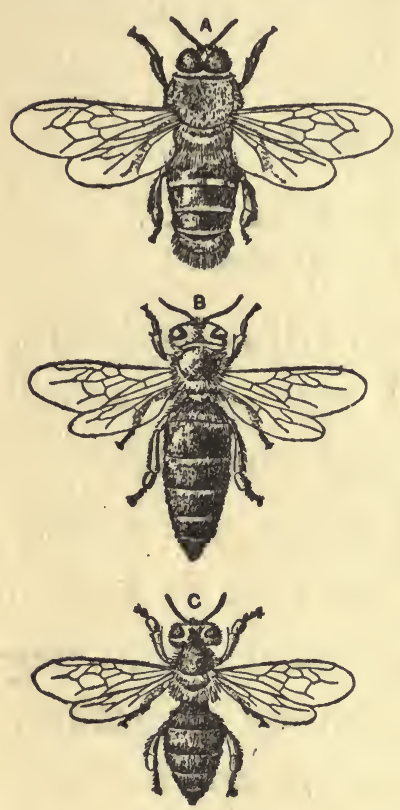

FIG. 1 .

Honey-BeE. - A, Drone; B, Queen; C, Worker. (After Benton, Bulletin I. (n.s.) Div. Ent., U.S. Dept. Agric.) As in the Ency. Brit. I Ith Edn. comprise three ranks: (i.) The queen, as a rule but one at a time, is very literally the mother of her people, for she alone lays eggs; (ii.) the workers, in structure females though - with rare exceptions - never laying eggs, but doing with tireless energy the whole work of the hive; the drones or males, absolutely useless except that amongst them one will be found-probably the strongest-who fertilises the queen-bee.

Let us consider for a brief space the activities of these varying ranks. A hive has swarmedthat is to say, a number of workers, together with a smaller number of drones and the existing queen, have left the hive and are hanging 
clustered together in a mass of moving insects, perhaps as small as a cricket ball, perhaps five feet in height and at its widest a foot or more in diameter. The swarm either finds a new home for itself in a hollow tree, or more usually is " hived" by a bee-master in a skip. After cleaning out and if necessary smoothing the walls of their new home, the worker-bees immediately begin the formation of the wax-combs. An uppermost row of bees clasps the roof of the hive with their forelegs supporting other rows below them, until we find a living veil of bees hanging from the roof

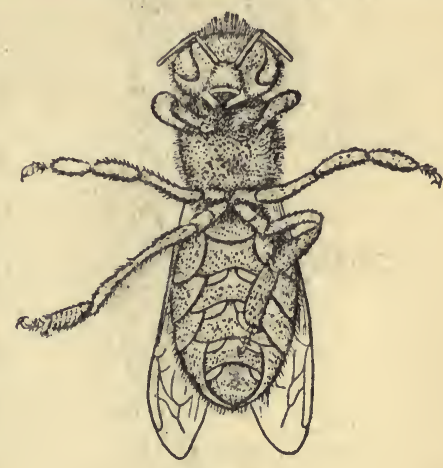

Frg. 2.

Ventral view of a worker bee in the act of removing a wax scale with its left hind log. The two middle legs and the right hind leg are used for support. (Casteel.)

of the hive. All these bees are secreting wax on the wax-plates of their abdomens. To produce this they must previously have consumed much honey. Latter tells us that to produce I $\mathrm{lb}$. of wax I5 lbs. of honey must be eaten. Fig. 2 shows how the wax-plates are disengaged from the abdomen and passed forward to be moulded by the mandibles. 
Right and left of this veil of bees will be parallel

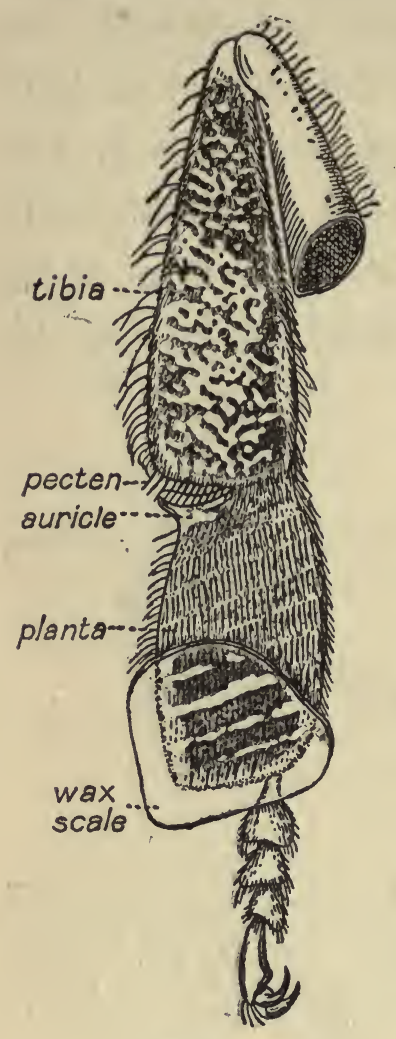

FIG. 3 .

Inner surface of the left hind leg of a worker bee, showing the position of a wax-scale immedi. ately after it has been removed from the wax pocket. The scale has been pierced by seven of the spines of the pollen combs of the first tarsal segment or planta. The jaw of the so-called wax shears or pincers are formed by the pecten spines above and the surface of the auricle below. (Casteel.) living veils engaged in forming other combs so accuratelyspaced that ultimately the empty plane between two finished combs is just wide enough to allow two bees to pass each other. The topmost row of bees, after kneading and moulding the wax with their jaws (mandibles), press it in a line along the roof to form a foundation for the comb. This of course is an upside-down foundation, for bees construct their comb from above downwards. More wax is then supplied by the hanging bees below, and passed forward to the builders of the foundation. As soon as the foundation is secured, the living veil disintegrates and the constituent bees begin 
to work independently at the building of the comb. No bee or group of bees works at one cell or group of cells; always fresh workers are coming and fastening their mite of wax to one or the other part of the comb. All seems unorganised, undirected, confused and without guidance. There is no foreman builder, there is no experience for many of the builders have scarcely emerged from the pupa stage for three days, there is no means even of seeing for the inside of a hive is pitch dark. Yet the bees produce with machine-like rapidity and mathematical accuracy a cell so uniform in size that " au moment de l'établissement du système décimal, lorsqu'on chercha dans la nature une mesure fixe qui pût servir de point de départ et d'étalon incontestable, Réaumur proposa l'alvéole de l'abeille."*

Bees and wasps also have learned that to obtain most space with the use of least material and consequently less labour, the columnar cells should be six-sided in cross-section. The vertical comb of bees consists of two layers of cells back to back. The bottom of each cell is a three-

* Maeterlinck, "La Vie des Abeilles," p. I34. 
sided pyramid, just the shape that is seen when the eighth part of a cube is removed; on the six edges thus shown the six sides of the cell arise. The walls of the cells are not of uniform thickness; they become thinner as they near the mouth, which, however, has a thickened rim. These cells are at first all of one size and serve as the homes of the young workers and for the storing of the collected pollen and honey.

For after some weeks the inhabitants of the hive begin to think of rearing drones and queens. Appropriate cells for these are now prepared. The drone-cell has to accommodate a bigger larva than the worker-cell and is correspondingly bigger and about one-third deeper, but except in size the difference is negligible. Among wild honeybees drone-cells are often placed in special dronecombs, but in the artificial hive these cells are intermingled with the worker-cells. The queenbee cells, however, differ much more widely from the worker-cells. They are, to begin with, very few in number, usually four or five ; thirty seems almost to be a record in a flourishing colony. All trace of a six-sided column disappears; the cell is cylindrical inside, but irregular and often marked with the scars of worker-cells outside. 
The cell is about the size of an acorn; the walls are very stout, 2-3 mm. thick; and the mouth opens downward. As a rule these queen-cells stand out from the under edge of the workercomb, rarely are they found near the drones' cells. The worker-cells are used over and over again for successive breeds of these undeveloped females, and the same is true of the drone-cells; but as soon as the young queen has emerged from the royal-cell it is broken up, and the wax which formed its walls is carried off to be used elsewhere.

The "middle-plate" between the two layers of cells of one comb is separated from the

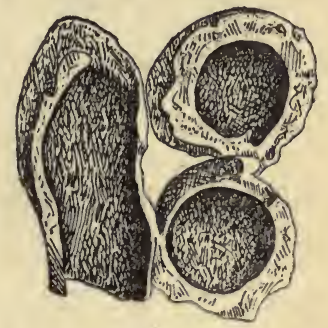

FIG. 4.

Cells of Queen Bee. Left longitudinal section. (Stadler.) "middle-plate" of the next comb by a space of $35 \mathrm{~mm}$. The depth of each brood cell is I2.5 $\mathrm{mm}$., and this leaves a space between each adjacent comb of Io $\mathrm{mm}$., room enough for the bees to pass back to back as they run over the open mouths of the cells tending the inmates. But since when filling or emptying the honeycells there is no need for the bees to pass one another, the honey-cells are deeper (I6-I7 mm.) 
and the space between them is consequently narrowed, and the bulky queen-bee cannot traverse it. The rate of growth of the comb depends on the rate of growth of the colony, and often it happens that the lower part is left in an incomplete state.

A young comb is white, translucent, very

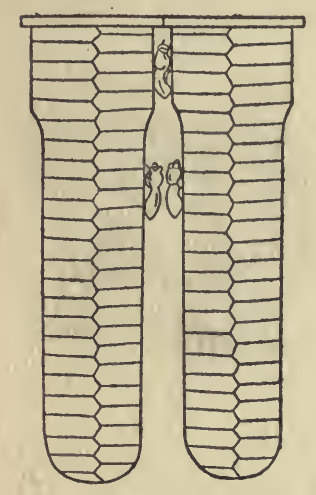

FIG. 5. brittle, but it soon hardens and toughens. The larva housed in each cell before turning into the cocoon spins a silken sac. When she emerges from the cell as a perfect insect, she leaves this sac behind her, and although the vacated cell is at once Diagram of comb show- and carefully cleaned out, this
ing honey-cells above. (Stadler.)

silken sac is suffered to remain, and so with each new occupant of the cell the number of sacs increases, adding greatly to the strength of the comb. The cells of old combs - and combs are often years old-may contain dozens of these silken webs, and although each is of extreme tenuity their accumulated bulk often necessitates an enlargement of the cell if it is to accommodate further larvæ. The 
cell-covers of the worker and drone brood-cells are convex, and are easily distinguished from the flat caps of the honey-cells.

One of the constant cares of the ever-busy bee is that of keeping the comb in repair, and constant reparation is needed. Another duty is to keep it clean. As soon as a cell is empty, it is "swept and garnished." Dust, fungi, dead bees, old remains of food, the dejecta of the queen and of the drones, are all removed by the workers. In fact, these indefatigable spinsters enjoy, as they deserve to do, a perpetual spring-cleaning, so dear to the female heart.

One other substance besides honey and pollen is brought by the workers into the hive, and that is the gummy, sticky exudation of certain trees -for instance, that of the horse-chestnut buds. This propolis, as it is called, is never stored in cells. It is used to stop crannies in the hive and so prevent draughts ; sometimes it is plastered nearly all over the inner wall, and at other times invading snails or moths, or even mice, which are too big for the bees to remove, find a sticky sepulture entombed in propolis within the hive : 
"And with their stores of gather'd glue contrive To stop the rents and crannies of their hive.

No bird-lime, no Idean pitch, produce

A more tenacious mass of clammy juice."*

An average hive will contain some 30,000 workers, 2,000 drones, and one queen, but in a strongly stocked community these numbers may be doubled or even trebled. The queen alone lays eggs and is a fully functional female; she is bigger than the worker and her abdomen is enlarged to accommodate her enormous ovary which pours forth a ceaseless flow of eggs. The hind legs of the queen are devoid of those modifications which enable the workers to collect and store the pollen, the wax glands again are reduced and apparently never used. The drone is the male, he is bigger than the workers and the queen, and is more stoutly built; his hairs are densely placed and short, his eyes are so large that they meet on the top of the head, the hind legs have no modifications for pollen-collecting, etc., the antennæ have an extra joint, his hum is deeper and louder than that of the workers. $\mathrm{He}$ has altogether a stronger and more virile organism, and yet with the sole exception of 
fertilising the queen, he does absolutely nothing helpful in the life of the hive.

When the queen moves on her egg-laying progress she first explores each empty cell with her antennæ, putting her head deep into the cell; then turning round she clasps the edge of the cell with her hind legs and inserting her abdomen deposits a single egg in the centre floor of the cell. Then she passes on to the next cell, and never does she tire or in any circumstance miss a cell. During this progress she is accompanied by a small court of worker-bees who, as courtiers should do, walk backwards before her. Some of them are engaged in fanning the queen with their wings, others stroke or lick with their "tongue" the royal thorax or abdomen, others feed her on their half-digested "pap" or " royal jelly," and all are humming in a most soothing and agreeable manner.

A young queen at the height of the season (May or June) lays some 2,000-3,500 eggs in the four-and-twenty hours. After the second year her fecundity is somewhat abated, but in the course of her four to five years' life she produces many hundred thousand ova. To show the measure of this amazing power of metabolism, 
Dr. H. Stadler has calculated that one gram of bee flesh will yearly produce IIo grams of bee eggs! There is, however, a peculiar relationquite inexplicable-between the state of the hive and the number of eggs laid. The latter varies with the strength of the community; if the number of the hive is in some way lowered, the egg-laying is intermitted. No egg is laid unless there are enough able-bodied workers to tend the resulting larva. In the tropics the activity of the hive does not vary all the year round, but in temperate climes the queen ceases laying in the autumn and retires into winter quarters to recommence her task early in the following spring.

In the worker-cells and in the queen-cells the queen lays fertilised eggs; but in the drone-cells the eggs are, as far as is known, invariably unfertilised. The birth of the drone or male bee may therefore be described as a case of parthenogenesis. What stimulus induces the reproductive organs of the queen to give the spermatozoa access to the egg in the former cases, and to withhold it in the latter is not understood. It can hardly be a matter of season, for the worker-eggs are laid at all times, the drones only when the swarming of the hive seems imminent, and the 
queen-eggs later than the drone. Neither can it be the stimulus of the variation in the size of the cell, for if all the large male-cells are removed, the queen will lay an unfertilised egg in a workercell, and conversely should the stock of workercells be exhausted she will lay worker-eggs in male-cells. The five or six queen-eggs laid in the spacious royal-cells are not laid simultaneously, but one after another at intervals of one or two days, and the resultant young queens emerge at similar intervals. This arrangement hasanimportant bearing on the swarming of the hive.

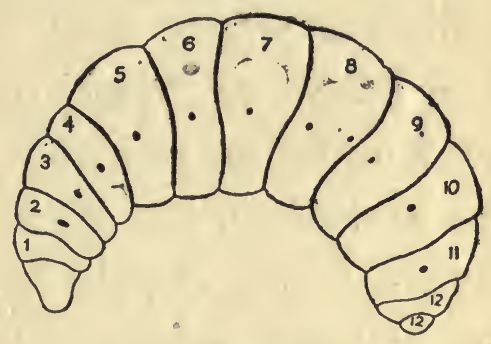

FIG. 6. Bee-Larva (after Fleischmann).

As soon as an egg is laid the motherly instincts of those "barren virgins" the worker-bees are aroused. They push their heads into the cell and apparently do something to the egg, though no one knows what. Within three days a minute white, maggot-like grub emerges and at once demands the attention of several workers. It is devoid of almost everything we associate with bees. It has no wings, no legs, no sting, no antennæ, no eyes, no proboscis, no hairs, no 
hard chitinous cuticle, only one pair of salivary glands (not three) whose secretion will soon harden to form the case of the cocoon; the alimentary canal ends blindly, and indeed the digestion of the small larva is so complete that there is no reason why it should end in any other way.

As soon as the larva has left the egg-shell the workers hurry up with a supply of nutriment. At first this consists of food which they themselves secrete from their salivary glands. It is known as "pap" or "royal jelly" and has a white or yellowish jelly-like appearance. The workers fill the cell with this food and the larva not only eagerly laps it into her mouth but probably absorbs this pabulum, in which she floats, through her tender skin. On the fourth day the worker-larva is partially weaned and her food is now mixed with honey; after the same period the drones are completely weaned and are henceforth fed entirely on honey and pollen. The queen-larvæ, on the other hand, are always and solely fed on "royal pap," and consume great quantities of it, the roomy royalcell being flooded with it. This food has an extraordinary effect on the future of the brood; if continuously given to a larva of the worker- 
class that larva will develop into a queen-bee; if continuously given to a drone-larva, the resultant drone will be of an enormous and monstrous growth, but its testes will suffer a fatty degeneration and disappear.

After five and a half days the queen-larvæ, and after six days the drone and worker-larvæ, cease to feed. The worker-bees now close with a convex cap the cell which shelters the larva, and the entombed "infant" proceeds to secrete from its salivary glands a cocoon-case which fills the cell, except in the case of a royal-cell where the cocoon occupies about one-third of the space. Within this the larva becomes first a "pronymph" and then a true pupa in which the body of the adult bee is being rebuilt from the disintegrated larval tissues. On the " allotted day," when the chitinous cuirass of the adult has to some extent hardened, the young bee is ready to leave her cell and commences to gnaw through the waxen cover of the cell, a task in which she is helped by numerous workers outside. Soon the way is cleared and she staggers forth into the darkness, heat, and bustle of the hive. Attendant workers wait upon her, arrange her dishevelled hairs, clean her, and offer her 
52 STUDIES IN INSECT LIFE, ETC.

honey to eat. But she has undergone a resurrection, and is at first bewildered at the new world into which she has stepped, trembling and feeble. Soon, however, things settle down, her wings expand and harden, her legs lengthen, and without guidance, without experience, she in a short time is beating her wings and dancing over the cells now ready to open for the exit of her younger sisters. Both drones and workers require two days to become really active and capable of full power but half a day suffices for the young queen.

Neither workers nor drones quit the hive till the sixth day after emergence, but the time of the workers is not wasted; hanging in motionless but living garlands, they secrete, from four pairs of "pockets" situate on the under-side of the abdomen, eight plates of snow-white wax' as light as foam; they also secrete the royaljelly and with it feed the larvæ; they carry to the "honey-pots" the honey brought into the hive by older workers; they press with their heads into the pollen-cells the pollen collected by their elders; they help the emerging bees into the outer darkness of the hive; they cleanse the vacated cells, and, standing in parallel rows, 
obliquely one behind another, they regulate by the fanning of their wings the ventilation of the hive and drive off the superfluous water in the "nectar" until it obtains the consistency of honey. All this is done, and done well, without guidance, without previous experience and without practice.

Only after a week or eight days do our young workers emerge into the light, and this great adventure is fearfully and timidly undertaken. Crossing the threshold of the hive, they attempt at first short flights, enlarging them each time, but never do they turn their head in any direction save that of their hive and their home. During their first flight their tracheæ-their breathing-tubes -are for the first time filled, and they now attain their normal figure. Soon, however, they return to resume their household duties, for, like Martha, they are "cumbered about much serving." Day by day, if the weather be favourable, these trial flights are resumed about noon, until the young workers are well orientated as to the position of their hive amongst surrounding objects, and as a rule many of the younger bees and drones fly together, producing a veritable cloud of flying insects. After another eight or ten days 
the workers are strong enough to go in search of honey, pollen, water, or the sticky propolis.

Both colour and scent in the flowers attract the bees; their favourite hue is blue and certain purplish reds; then come in descending order, violet, red, white, and lastly yellow. When collecting the pollen, the bee hovers close to the

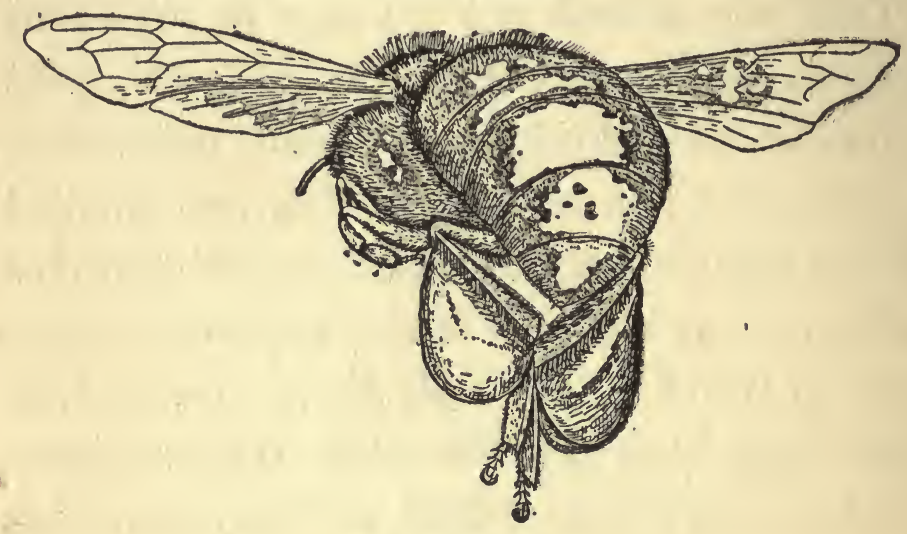

FIG. 7 .

A bee upon the wing showing the manner in which the hind legs are held during the basket-loading process. Pollen is being scraped by the pecten spines of the right leg from the pollen combs of the left. (Casteel.)

flower and besprinkles the anthers with a little honey and saliva, then approaching the blossom she kneads the now moistened and sticky mass of pollen with her jaws, and finally packs it away in the baskets or corbicula on the outer surface of the tibia of the last pair of legs. But much pollen is collected in a more indirect way. 
As the bee moves about in and on the flower, pollen-grains fall all over her body and readily adhere to the branched hairs which are thickly scattered over its surface. The first joint of each foot (tarsus) is provided with a thick coating of moistened bristles, and these are used

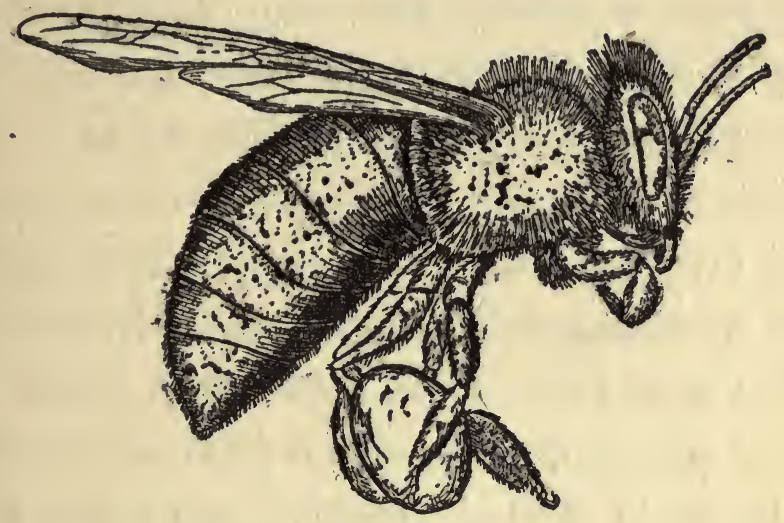

FIG. 8.

A bee upon the wing, showing the position of the middle legs when they touch and pat down pollen masses. (Casteel.)

to brush together and collect the pollen scattered over the body of the bee.

Unless the honey-harvest be unusually bountiful the young bee which has just started collecting food will confine herself to pollen, but after some days she will turn her attention to honey, or rather to nectar, which is not at all the same thing as honey. The proboscis is sunk into the nectaries of the flower and their sweet juice is 
sucked up. The nectar is stored in the so-called honey-crop for transference to the hive, and when a bee is seen seeking her home with her abdomen distended by a full honey-crop it is useless to search her for pollen; reciprocally a bee whose hinder legs are burdened with pollen has ever a slender abdomen. Except at the time of swarming, when the bees that leave the hive gorge themselves with honey so as to have some provision for their new home, no worker ever leaves the hive laden with honey. A bee with a swollen abdomen is always a homing bee.

The area from which bees collect nectar and pollen usually extends over a circle whose radius is three to four kilometres, although, under special circumstances, i.e., an unusually rich supply of nectar, bees may fly six or even seven kilometres, but first they carefully orientate themselves so as to fix the position of the hive in their brain. The return journey causes no trouble and is quick, a heavily-laden bee flying home at the rate of I2 to 20 kilometres an hour. A bee without honey and without pollen is said by some observers to fly at the rate of 32 kilometres an hour, whilst others claim that a speed of 65 kilometres an hour can be attained. 
Nectar is a sweet watery fluid which in almost every case has a specific flavour associated with the flower from which it is drawn. This specific flavour as a rule disappears in the honey, which is a much less watery fluid than the nectar. The several changes which nectar undergoes in becoming honey begin in the honey-crop, where the saliva of the bee mixed with the nectar of the flower starts the transformation of the cane-sugar of the nectar into the dextrose (grape-sugar) and lævulose (fruit-sugar) of the honey, and this process continues after the fluid has been deposited in the waxen cells. When honey is plentiful the cells stored with pollen will receive, before they are covered in, a little honey as well as a little saliva, together with a minute drop of formic acid which acts as a preservative or antiseptic. The need of honey in the hive surpasses. that of pollen, and the honey-cells are more numerous than "bee-bread" cells. The stored honey and pollen serve for the daily food of the workers, the drones and the queen, but in a healthy hive there is a surplus store, and this surplus store enables the whole community of honey-bees to last year after year, whilst the existence of, say, a wasp-nest depends on the success of a single 
individual in tiding over the winter months. Although in the winter the activities of the hive drop to a minimum, still there is some movement of the bees and so food is imperative.

The fresh nectar poured out of the body of the bee contains 80 per cent. of water and is very fluid. Why it remains in the cell and does not pour out before the cell is "capped" is rather a mystery. Truly, the cells are tipped a little upwards, but not enough to explain this later when it thickens into honey it may be said to be too viscous to flow out yet if the comb be lightly shaken down it comes in a sweet and sticky stream. One of the most interesting factors in the conyersion of nectar into honey is the removal of the superfluous water. The worker-bees after a hard day in the field return to the hive, and after depositing their evening harvest take their stand in serried rows and begin fanning with their wings. Tireless and apparently without fatigue they continue this exercise hour after hour until the rising of the sun recalls them to their harvest fields. A good hive will in the course of a night drive out of a "skip" an amount of aqueous vapour equivalent to $I \cdot 5$ litres of water, and so gradually the amount 
of water is reduced from 80 per cent. in the nectar to 25 per cent. in the honey. Both worker-cells and drone-cells are used for storing honey, and if the supply necessitates the building of new cells to house the precious fluid, drone-cells are built, for they are easier to construct and require comparatively less wax.

Dr. Stadler has made an ingenious calculation as to the number of journeys a worker-bee makes at harvest-time, and arrives at the conclusion that each bee makes between 75 and roo flights a day. Even bee protoplasm cannot stand such a life. Working like the students at Osborne or Dartmouth " at the double" all day, standing with vibrant wings all night, occupied with the cares of the hive in between times, never having any sleep, never taking any rest, it is little wonder that the frail body of the worker is at the height of the season worn out in five or six weeks. True to her devotion to the cleanliness of the hive, she usually dies outside it, but if by any chance she dies inside, the body is removed by the survivors like any other piece of lumber. Vergil's statement put into English by Dryden :

"Their friends attend the herse, the next relations mourn," 
cannot be justified even by poetic licence. The friends and relations are totally indifferent. Bees know neither love nor regret.

It is the general rule amongst the social Hymenoptera that new colonies are started by the unaided efforts of a single queen, but this rule is broken by the honey-bee. Here the queen when starting a new colony is accompanied by a large number of workers and a few drones, the whole constituting the swarm. The preliminaries to swarming are many; the first is the laying of unfertilised eggs in the drone-cells old or new, for the drones take the longest time in reaching maturity; then a certain number of queen-cells are built and provided with fertilised eggs laid each some time after the other so that they will be ripe for entrance into the hive at successive intervals of forty-eight hours. When once the cover is placed on the first of these royalcells, which hang usually to the number of six or eight from the lower edge of a comb, with the mouth downwards, the reigning queen becomes restless. She intermits her egg-laying, moves uneasily hither and thither, and with an unbridled jealousy tries to break into the royal-cells and so destroy her royal offspring and possible suc- 
cessors. These cells, however, are safely guarded by the workers and seldom does she succeed. If the weather be favourable and if the provision of honey and bee-bread be ample, the workers are also seized with the demon of unrest. Those engaged in collecting nectar and honey cease their labours and remain at home. On a still, warm day in May or June numerous bees may be seen resting and motionless outside the hive; these are joined by others, and gradually they all collect together and hang like a beard in front of the hive. More bees attach themselves to the beard, and then suddenly the whole thing breaks up and the constituent bees pour into the hive and fill them- Schajo), from Dr. Stadselves up with honey as a Biene."

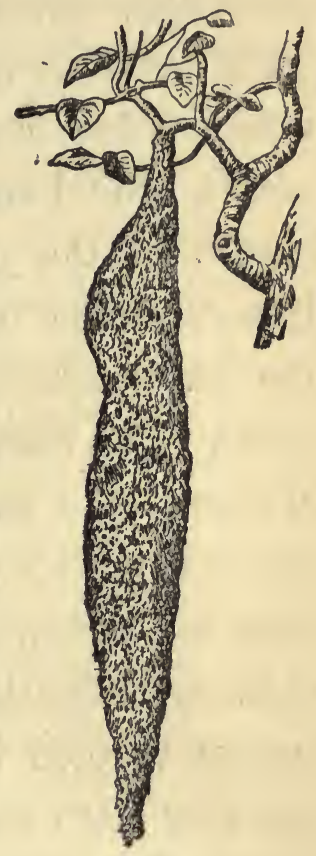
FIG. 9. provision for their future home. The excitement within the hive increases, the noise becomes louder and louder, and then suddenly a vast stream of bees, both workers and drones with their queen, pours out of the mouth of the hive 
in a state of delirious tumult. Soon, however, they settle on some bough or wall chosen by the queen. Some hang to the support, the others hang on to them. The queen is hidden within the living, seething mass. Here the swarm may hang for hours and even for days, but as a rule within a few hours they are guided by certain scouts, who have been investigating the possibilities of the neighbourhood, to some hollow tree or shelter under a roof and to this retreat the whole swarm flies by the shortest possible route. The workers at once set to work to clean the new hive and to prepare the comb and as soon as possible the queen resumes her interminable egg-laying. It may be noted that whilst thus swarming the queen sees the light for the second time in her life. When swarming, bees are very loath to sting, and, according to Latter, should they do so the sting is " comparatively innocuous." An average swarm is about the size of a football and weighs about $4 \mathrm{lbs}$.

The hive which the swarm has left has for the time no queen, though potentialities of royalty exist in the numerous royal-cells. As soon as the first of these young queens is ready to emerge she bites through the cover of her cell, 
aided by some of the remaining workers, and steps into the hive; but this does not take place until eight days have elapsed since the swarming. As soon as the young queen has been cleaned and has acquired a little strength and her wings have hardened, she begins to move about, and when she becomes aware of the other royal-cells with the pupæ of her sisters therein she becomes violently excited, utters a well-known war-note, and attempts to tear open the cell of the oldest. Sometimes this is permitted, and the ruthless young monarch slays with her sting in turn the whole succession of royal infants. Should her strength fail her the slaughter is continued by the workers, who in any case greedily consume what royal-jelly is left in the cells, and draw the corpses of their victims out of the cells and cast them out of the hive.

This process of slaughter is, however, a very risky proceeding, for if anything should happen to the conquering and sole remaining queen on her wedding-flight, or at any other time, and if there were no larvæ under three days of age (these can be reared into queens by a continuous diet of royal-jelly) the hive would become queenless, and a queenless hive rapidly 
falls into a state of "death, damnation, and despair." Therefore the bees usually guard the cells until the first queen has been fertilised and has returned to the hive, and also until it has been clearly settled that a second swarming is not to take place, for in that case the first hatched queen would lead the swarm and one of her sisters would be wanted to replace her in the hive. Should there be a second swarm it will centre round the young queen as yet unfertilised, and it may be that some of her sisters may then escape and join the swarm, in which case it either breaks up into as many small swarms as there are queens, or the queens fight till but one remains, or the workers put all to death save one. A fight between two queens is a venomous and a deadly affair. Although sisters, although members of the same exalted and exiguous caste, they seem to be animated by the bitterest hatred, yet so strongly implanted in their being is their devotion to the future of the community that when, as they sometimes do, they get into a mutually murderous position where a stroke of the sting of each would kill the other, they immediately cease fighting and retire trembling for a time, 
apparently appalled at the prospect of the queenless hive which would result from their killing each other. After a time, however, the combat is renewed and one or other is slain.

Sometimes when a second queen enters the hive and the reigning queen is busy laying eggs, the presence of the intruder is concealed and a crowd of workers surround her on every side, "balling" her in until she dies of hunger and suffocation, but they never sting her to death.

For the first few days (from two to six after her birth) the young queen shows no disposition to be married. Then a change occurs. She becomes restless, runs to the hive-mouth and back and presently makes a short experimental flight, for the first time seeing the sun and inflating to the full her breathing tubes. Soon she takes wider flights, always keeping her head directed to the hive. After a time she is followed by a group of drones, and as she towers into space one by one these suitors drop off until one, the strongest, remains to mate with her high up in the heavens. The act of mating is fatal to the male. It is thought that he dies of nerve-shock. Whatever the cause, most of his body falls dead to the earth, but he leaves 
part of it in the queen; this can only be removed when it has shrivelled up, and then, in some cases, only by the aid of the workers. The fertilised queen returns to the hive, having in her spermatheca no less than 200,000,000 spermatozoa, a supply equal to even her prodigious fecundity.

Once the queen is fertilised and has begun her ceaseless egg-laying the drones are more useless than ever. They have always been a nuisance in the hive, devouring the best honey, hustling the workers, impeding the work and fouling the combs; for, unlike the workers who can only rid themselves of undigested food when on the wing, the drones and the queen deposit their excreta in the hive for the workers to clear away. Useless, and a great drain on the hive, they are yet suffered to survive a little while, but in a few days that curious socialistic instinct that persistently impels the honey-bee to sacrifice the individual for the sake of the community - "l'esprit de la ruche" as Maeterlinck calls it -is awakened, and the workers unite to destroy the drones, either by driving them forth, or by forcing them into an empty comb and starving them to death, or by savagely attacking them 


\section{THE HONEY-BEE}

with sting and jaws, till they are killed outright.

The same "esprit de la ruche," the same overwhelming instinct to provide at all costs for the continuance of the race, causes the workerbees to work themselves to death in a few weeks for the sake of succeeding generations, and condemns the queen-bee to a life sentence, which often takes four or five years to work out, of penal servitude of perpetual parturience in pitchy darkness. 
Chapter III

\section{BOMBUS, THE HUMBLE-BEE}

THERE is something friendly, something homely about the humble-bee which is entirely lacking in the more specialised honey-bee and in the rather terrifying wasp. Perhaps it is the popular delusion that they have no sting which endears them to us. Nevertheless, this is a delusion, for both the queen and the workers have stings and occasionally use them, but the poison is weaker than that of their allies and the pain inflicted correspondingly less. On the other hand, certain advantages rest with the humble-bee, it does not, like the honey-bee lose its sting when used but can withdraw it and use it again another day. Unless handled or. misused, however, the queens do not sting human beings, though if the nest be disturbed in an unmannerly way the workers will often strike out. The economy of the household is also more attractive to the average man than is that of the bee-hive. It 
is less ordered, less specialised, and is carried on more on the lines of the comfortable city firms of a century ago and less on the lines of an upto-date trust or syndicate. Few trusts or syn. dicates awake our deeper affections, and, as Bagehot said about Political Economists, "No one really mourns when they die."

Humble-bees are dwellers in cool or, at any rate, temperate climates. Perhaps they flourish best about our latitude, but they are found far north passing the seventeenth parallel, and their comfortable and homely booming is a welcome, if unexpected, note in the monotonous wastes of Greenland, Siberia and Alaska. But few species occur in the Tropics, though they are found high up in the Himalayas. Africa does not know them except along the Mediterranean Coast, and, until introduced into New Zealand, they were absent from Australasia.

Altogether there are some hundred species of Bombus with a very large number of varieties or sub-species. Of these, seventeen species occur in our islands. The genus Bombus differ from other bees in many particulars, but two of the most striking are manifestly well adapted for life in cold regions; the body is short and stout and the 
hairy covering is unusually dense and thick. To distinguish one species from another is no easy task; to begin with, we have three grades with which to deal-the queens, the workers and the males. The last named can be determined by the outline of the armature, which corresponds with the sting in the female, but care must be taken in investigating this, as the parts of this complicated structure are easily displaced and the outline of the whole is thus altered. Much also depends on the colour markings, and here the admirable colour-photographs published by Mr. Sladen in his monograph on the humble-bee cannot fail to be of the greatest use to naturalists. Still the colour is apt to vary within the species, and in systematic work it is quite usual to speak of "light specimens" and "dark specimens." Further, the colour of the hairs is apt to fade with time and, altogether, there are many pitfalls before the systematist in humble-bees.

If we try to trace the history of the humble-bees' nest we may begin with the queen in the late summer. The active season of such a nest is shorter than that of Apis or Vespa, the closed time longer. The final activity of the corporate life is the rearing of queens in the later part of 
July or in August. Once grown up the queen, as a rule, soon leaves the nest, but she is " a shy bird" and hides herself away in some cranny or among some débris. Here she is diligently sought for by the males, which pause at every likely spot and emit a very pleasing scent, possibly to attract the queens. Sometimes they try to intercept their brides as they leave the nest, but in any case the queen, once fertilised, abandons her home, which soon falls into decay, and seeks for winter quarters. Before leaving the nest she has filled up her crop with honey, and this must suffice her for food during the next nine months or so, when she is en retraite. The queens of some species (B. terrestris) like to winter in burrows under trees, those of others (B. lapidarius) high up in banks. But whatever habitat is chosen, damp must be avoided and the aspect must be northerly. This latter is also true of hibernating wasps, and the explanation is not far to seek. These burrowing insects are aroused to activity by the warm spring sunshine; should their winter home face south, a single exceptionally warm winter's day might awake them. They would emerge to find the world unready for them and perish without founding a colony. Getting 
up too early with them is as fatal as not getting up at all. The retreat of the queen, at any rate in the species $B$. lapidarius, is often revealed by little heaps of sand or earth, excavated as she tunnels the bank to a depth of two or three inches. At the end of the tunnel she carves a spherical cell an inch or more in diameter. At first she sleeps but lightly, and if disturbed by any cause will emerge from her "cell" and fly away to build another ; but as winter approaches and the days become cold, she sinks into a deep lethargy, simulating death. This torpor lasts eight or nine months. Those species who go early to bed begin to stir as early as March; those that retire later may not resume their activities until May or even June.

As the spring advances the queens reappear, and "may be seen busily rifling the peach blossom, willow catkins and purple dead-nettle," but at first they nightly retire to their hiding places. Soon, however, as the days lengthen, the desire for starting the colony becomes irresistible, and a home is sought out, usually one already made and abandoned by some field mouse or other small (burrowing) mammal. For most of the nests are underground, and are approached by a tunnel which may be three feet in length. 
Other species-and these are the so-called " carder bees"-construct nests of moss and grass on the ground, but hidden from sight in thick grass or under ground-ivy.

Having started her home, the first concern of the queen is to orientate herself so that she may find her way back to it, and this she does by a series of trial flights in ever-widening circles. Now she begins to collect both pollen and honey, and mixing the two, constructs in the centre of the nest a stumpy pillar of this pollen paste, on which she moulds a circular wall of wax. In this rough cell she lays her first batch of eggs, usually about a dozen, and seals this common chamber by wax manipulated with her jaws. The eggs are large, much larger than those of Apis, $2.5 \mathrm{~mm}$. to $4 \mathrm{~mm}$. in length, elongated, like sausages. Over them the queen broods, and, except to gather food, does not leave them night or day. Provision must, however, be made for a "rainy day," and to this end she prepares a waxen spherical honey-pot of considerable size, perhaps three-quarters of an inch in diametera fragile affair of thin and soft wax, but watertight and capable of lasting some weeks. Set in or near the entrance of the nest, it affords a 
readily accessible store of food to the queen as she passes in and out. Owing to the amount of wax required, the honey-pot takes some days to make, and when made it is constantly being remodelled. In the morning, when it is half empty, its walls are lowered, to be rebuilt and the orifice narrowed at night-time when it stands full. The honey itself is thin and watery, much more so than the finished product of the honeybee. "Weak but palatable," as Mr. F. found the wines of France.

Four days after they are laid the eggs hatch and twelve little curved, whitish grubs emerge into their waxen cell. They quickly begin to feed upon their pollen bed, to which fresh pollen is being added by the queen. From time to time, also, she pierces the cell and at first injects a common food of mixed honey and pollen; but later, when the larvæ are larger, each is individually and compulsorily fed. The larvæ now press on the enlarged waxen cell, and soon the position of each can be recognised by an individual bulge on the outside. In a week they are full grown, and now each spins about its body a thin, papery but tough cocoon. This done, the queen removes the remains of the waxen cell 
and so many pale yellow cocoons, standing on their ends like erect mummies, are revealed to the eye. The cocoons are fused together, and those in the centre of the compacted mass are not so high as those on either side. Thus a groove is formed, and in this groove the queen lies, stretching out her abdomen to an amazing extent. Brooding thus, often motionless for half an hour, she is giving the warmth to the chrysalides which alone is now needed to bring forth the first batch of workers. In eleven days from the cocoon building the perfect worker is completed, and each, biting an exit, steps into the outer darkness, for it must not be forgotten that the interior of the nest is black as night. At first dishevelled and absurdly weak, the newly-emerged worker has at least enough sense to totter to the honeypot and take a deep draught before returning to nestle in warmth and safety beneath the body of her mother. In a couple of days, however, the workers are well groomed and are beginning to help in the work of the nest, collecting pollen and honey for the second and later broods of larvæ which arise from successive batches of eggs that the queen has from time to time found leisure to lay. 


\section{STUDIES IN INSECT LIFE, ETC.}

While the larvæ were busy weaving their papery coverings the queen has been busy laying further batches of eggs in little waxen cells, which she fixes to the outer edge of the mass of cocoons. Every two or three days a batch is laid until the central block of cocoons is wreathed about with waxen cells containing six to twelve or more eggs and larvæ in all stages of development. These cells lie on the outer edge of the cocoons and in no way interfere with the emergence of the imagos. By the time the first workers have emerged from the primary batch of eggs the larvæ of the second batch are approaching that stage of their development when most attention is needed and thus little time is wasted. The worker among the honey-bees does not begin the task of gathering food until she is about two weeks old, though in the meantime she has been employed on certain domesticities within the hive. The worker humble-bee, however, begins to fly and to bring back honey and pollen by the time she is two days old! The former collects either nectar or pollen, but not both, on any one journey, and the pollen is usually uniform, i.e., from one species of flower, but the humblebee brings back both nectar and pollen, and the 
latter is of many kinds, so that the burden of her thighs is streaked with white, lemon, yellow, orange and bright red pollen grains.

If the first three or four batches of eggs hatch out into healthy and vigorous workers, the queen, who, after four or five weeks' incessant toil, is somewhat the worse for wear and obviously tired out, relinquishes her outdoor labours and confines herself to laying eggs and tending the larvæ at home. Should, however, the young brood prove weak, either in numbers or in physique, she sacrifices herself to the public welfare and continues to gather food. A curious relation exists between the amount of food supplied and the size of the recipient. The early broods, when the queen alone, or the queen and a few workers, form the Army Service Corps, are smaller than the later broods, who have scores of workers to minister to them. Again, a few of the larvæ are necessarily pushed a little to the side as the crowded waxen cells increase in bulk, and they may even have to form a horizontal cocoon instead of a vertical one. Such larvæ fare ill as to nourishment and develop into dwarf bees, úsually with defective wings. They may be no bigger than a house fly. Should, by some 
accident, a larva leave its waxen home prematurely, it is at once removed from the nest and perishes.

When fully established the workers cease to make use of the queen's honey-pot, which falls into decay, but they store their honey in the cocoons they have vacated, strengthening the rims, with wax. But in some species the workers construct special honey-pots of their own, smaller than the original one, but at times quite numerous-twenty or more. The latter contain a thin and watery syrup which is daily consumed, but in the cocoons a thicker honey is stored against a period of want, or as a provision for the young queens. As we have seen, the first pollen collected by the queen is placed within reach of the hungry larvæ, but there is no special receptacle for it. Later special receptacles are made for its storage, and these differ in different species. $B$. lapidarius hoards pollen in cocoons, $B$. terrestris and $B$. lucorum in a few specially constructed waxen cells, while the "carder-bees" stock their exiguous store in little pockets on the side of the waxen homes of the larvæ. In no case are honey and pollen mixed in the same receptacle, and, as with the honey-bee, the humble-bee trusts its 
pollen cells nearer to the brood than the honey cells.

The comb, irregular and rough compared with the frigid rigidity of the honey-comb, consists of a basal layer of vacated cocoons, now used as store cupboards. On these rest the irregular wax cells containing larvæ, intermingled with cocoons containing pupæ, and traversed with lanes for the bees to move along " on their several occasions." On the cocoons, again, a cluster of small wax cells shelters the recently laid eggs. All is dark within; not only is the interior of the nest like night, but the entire brood is concealed under waxen canopies or papery cocoon cases. In large colonies of $B$. lapidarius the whole comb may be covered by a waxen dome, but always room is left for the bees to circulate, and in this they must be guided by a sense of touch or smell, for all is black within the nest. Their sense of scent is indeed acute; they recognise the smell of their own and other species, and also other animals they may come across. Human breath excites their active antagonism, they distinguish plants much more by scent than by sight and they almost equal the honey-bee in discovering nectar or honey. Owing to the greater 
length of their "tongue," Bombus can probe and fertilise flowers which are beyond the reach of $A p i s$; such are honeysuckle, the horehound and red clover, whose introduction into New Zealand proved a failure until the humble-bee was brought in to fertilise it. Unfortunately, one of the two species introduced from the Old Country, B. terrestris, has the habit of biting holes near the base of the snapdragon, the foxglove and the broadbean flower, to get more readily at the nectaries, and the colonists are apt to wish that another species had been selected for importation.

While the humble-bee hive is "in being"for but three or four short summer months-the inmates are excessively busy, working themselves, in fact, to death. They begin their foraging expeditions earlier in the morning than does the honey-bee, and they continue them until dusk. Even when retired for the night they do not rest, but spend the silent hours some in building, some in tending the young and others in brooding over the cocoons. After laying two hundred to four hundred eggs and helping to bring up the issuing larvæ, the queen, as the season is closing in, begins to lay special eggs destined to turn into males or fertile females (i.e., queens). The 
male brood resembles that of the workers, and is indistinguishable from it, but the queen cocoons and the queen larvæ are larger and readily recognised. There is little or no evidence that, as with the honey-bee, a special diet is needed to produce a queen. With the humble-bees royalty seems to be inherent in the egg. At times and in some species a certain jealousy is shown on the part of the workers, who try to destroy the male and the queen eggs, but the ovipositing queen is on the outlook, and although the attacks are often repeated, she usually succeeds in beating off the attackers.

Unlike the swaggering drones of the beehive, the male humble-bees leave the hive as soon as they can fly and fend for themselves. Henceforth they are no trouble to their sisters and no charge on the resources of the community. Both males and queens are produced in some numbers, certainly several scores. The latter take longer to attain maturity, and when they can fly they, too, leave the nest, though occasionally they return once or twice laden with pollen. Once mated, they leave for good and seek out winter quarters and so the cycle is completed.

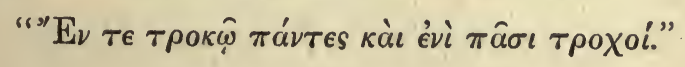


The old queen is now ageing fast, her fertility is falling off and hardly sufficient eggs are laid to keep the workers busy. At this time some of the latter may take to laying eggs and, as is the case with $A$ pis, such eggs always produce males. The aged monarch is now fast becoming bald, the hairs drop off, especially from the abdomen and the middle of the thorax. At the time of the emergence of the young queens the store of honey food is at its maximum - as many as four hundred cocoons containing thickened honey have been found in one nest, for it is on the young queens that the future of the race depends. Once they are started in life the workers become listless, flowers grow scarce, often what is left of the store food is soon consumed, one by one the bees disappear, the old queen grows torpid and drops asleep, and soon from this sleep there is no awakening.

At the beginning of this article we pointed out the attractions which the humble-bee possesses, in our opinion, over its allies, the honey-bee and the wasp. It is altogether a more human and a much less exasperating insect. It has none of the cold, glittering efficiency of the wasp or the maddening perfection of organisation of the 
honey-bee. You feel that you might appeal to the better feelings of Bombus, but that it were useless to do so to Vespa or Apis. The queen, again, has something of the mother in her. She is not reduced to an egg-producing apparatus, which lays eggs with the regularity and inevitableness of a recurring decimal. The queen humble-bee broods over her young, tends them and feeds them. The workers work as hard as any $A p$ is, but they seem less self-conscious about it, and the drones have the grace to provide during their brief life for themselves. It is true that the nest is more untidy, more littered than the hive; the domestic economy is Irish, not Dutch, but after all, what would life be without litter? 
Chapter IV

\section{ON CERTAIN DIFFERENCES BETWEEN WASPS AND BEES}

THERE is no better way to distinguish between social wasps and social bees than by their habits, difficult as these habits are at times to observe. There are, of course, structural features of differential value, some connected with their divergent activities; for instance, the proboscis for sipping the nectar of flowers is more complex in the bee than in the wasp and, as a rule, longer. In one genus, Euglossa, a tropical American bee, this far surpasses the total body-length, and when the insect is at rest projects behind the end of the abdomen like an extended "sting." Another curious point is that, alone among the hymenoptera, bees have feathered or plumose hairs. To make these out, of course, requires a microscope, but there they are and they are diagnostic. It has been suggested that their feathered hairs are especially well adapted for carrying pollen, 
but simple hairs in many Hymenoptera carry pollen, and certain parasitic bees, and the drones which never collect this " bee-bread" are equally provided with feathered hairs. Related to this pollen-collecting habit and also to the building up of a waxen comb certain modifications of the third or last pair of legs are present in workerbees, whereas in wasps the third pair of legs differs but little from the first or second pair and like them are primarily used for walking.

Bees are throughout their life vegetarians; both larva and adult are nourished on the products of the plant-world. Not so the wasp. Here the worker-insect feeds the young with animal nutriment; chewed up spiders, insects and pieces of flesh torn from-larger carcases are eagerly devoured by the grub-wasps hanging head downwards in their papery cell.

For here, again, is yet another distinction. The comb of the wasp is of a rough, coarse, paperlike material, not secreted by the body of the worker, but gnawed by the jaws or mandibles off some park-palings or other dried wood and kneaded up with some of the secretions of the glands in the head until it forms a paste. When dried, this paste looks like a dirty greyish coarse 
paper, and of this the cells of the comb and the coverings of the nest are formed. Later we must consider the whole question of wax which is used by the bee for its comb.

One last point of difference, and one I do not remember to have seen recorded, though doubtless it has been. The long axes of the cells of the wasp- and bee-combs lie at right angles to the base of each comb. The papery cells of the wasps' nest hang vertically from the roof of the nest, with the opening directed earthwards, but the waxen cells of the beehive project almost horizontally and the comb consists of two layers of cells placed back to back and with their openings east and west or north and south.

The colonies of both the honey-bee and of the social wasps contain the same three categories of individuals, (i) the males or drones, (ii) the workers which are imperfectly developed females, and (iii) the queens which alone are functional and lay eggs; but except in the late summer or early autumn, when all three categories are extant and active, there is a marked difference in the life of the beehive and the life of the wasps' nest. This difference rests on the fact that, as autumn approaches, the wasps' nest, like the nest 
of the humble-bees, disintegrates and disappears, while the hive of the honey-bee persists throughout the winter, shorn only of its drones, which are usually done to death by the workers. Two categories, the queen and the workers, live through the winter in the honey-bee colonies, inert and dormant it may be, but yet alive and ready to resume activities when spring arrives. The hive also remains, the comb is not destroyed, and after a little spring-cleaning will be ready for use again when next needed.

But with the wasps' nest things are far otherwise. As the autumn approaches and the cold weather comes on the young queens which have previously been fertilised by the drones retire from the world and hide away in moss or under a thatched roof or in some corner of a shed. Here they seize with their jaws some fragment of straw or bit of rag and, hanging on almost entirely by the jaws, wrap their wings around them and enter on their winter sleep.

Meanwhile the wasps' nest has been rapidly deteriorating. The activities of the workers fall off, the drones are slain or cease to return to the nest. The workers sustain life for a few more days by devouring the remaining larvæ and pupæ, 
but soon they also perish. The nest begins to crumble, and so the ruins of what was the home of one of the most highly organised of insect communities serve but to house field mice, earwigs, mites, beetles and woodlice. Seen under a diminishing glass

"the Lion and the Lizard keep

The Courts where Jamshyd gloried and drank deep."

It thus comes about that the whole wasp protoplasm (living matter) is throughout the winter months tucked away in the bodies of the queens which are hanging by their teeth in some remote crannie. In her body, and in her body alone, is the potentiality of the wasp's nest, and should she perish next year's wasps' nest perishes with her. This, indeed, often happens, especially during a mild winter with snaps of really cold weather. The dormant queen is little affected by cold, and can survive many degrees of frost, but if the temperature rises unduly she is apt to think the spring is at hand, to wake up and all too soon to resume an active life. In this condition a fall of temperature, which would leave her unaffected were she dormant, quickly brings 
her life to an end and with it all hope of the future wasps' nest.

Finally, the unique method of the fertilisation of the queen-bee by the drone differs from anything which takes place in a wasp. The fertilisation of the bee occurs high up in the air, and the male instantly dies and falls to earth, leaving, however, part of his body in the queen bee. Such a process is unknown in any other insect, even in the nearly allied humble-bee. There is no instance on record of a queen-bee being fertilised twice, and should she fail to find a mate she lays unfertilised eggs, which produce only drones. This means in a short time the end of the hive, for drones are useless, and the workers soon die off and the starvation of the brood ensues. It is a mystery why female egg cells not fertilised by the male cell (spermatozoon) should always produce a male, and that the same when united with the male cell should produce a female, but such is the case with other insects. 
Chapter V

\section{THE ROMANCE OF THE DEPTHS OF THE SEA}

ALL who have taken any interest in the investigation of the sea during the last twelve years will know the "Michael Sars," and the work done by her scientific staff in the North Sea. The ship was built by the Norwegian Government in Igoo to undertake researches into the Norwegian fisheries in connection with the international scheme of North Sea investigation, and to study the conditions under which these fisheries exist. She is essentially a first-class fishing trawler, specially fitted for scientific work. Her length is about I20 feet and her gross tonnage 226. Her engines are 300-horse power and can keep up a uniform rate of ten knots; but her coal storage is small, a serious consideration when the Atlantic is to be crossed.

Her voyage but a few years ago, on the scientific exploration of the Atlantic, took her outward 
across the southern part of the Atlantic Ocean, and homeward by a route between Newfoundland and Ireland. Starting from Norway, the " Michael Sars" made for the Canaries; from the Canaries she sailed to the Azores and thence through the Sargasso Sea to St. John's, Newfoundland, and so back to Glasgow.

There are many reasons for keeping a research ship of this kind small, not the least being the cost of up-keep, but it was somewhat of an experiment to take so small a vessel for a prolonged ocean trip; yet the experiment was eminently successful. This is, in our opinion, largely due to the fact that the men of science on board, as well as the crew, were not only exceptionally able men, but were men who thoroughly knew their boat and its capabilities. The list of the scientific staff contained some of the best known names in oceanographic research. Each of them was a master in his own subject, and each was a bold experimenter, and through them new methods and new machinery, which were successfully employed on this Atlantic cruise, have been given to the world.

The passengers and the crew of a liner racing over the surface of the Atlantic are apt to imagine 
that under them is a vast layer of water of varying depth sparsely inhabited by a few fish. As a matter of fact the whole of this great ocean is teeming with life. If instead of taking ship we could take to the water and walk across the bed of the Atlantic to America, starting from the shores of Western Europe, we should in effect be travelling through a succession of new countries. Not only would the surrounding physical conditions vary as we advanced, but the animal and plant life would vary in correlation with the altering physical conditions. We should soon leave behind us the larger seaweeds of our childhood's seaside visits, such as the bladder-wrack, and the belt of mussels, barnacles, limpets, periwinkles, dogwhelks and small crustacea, sea-anemones and worms, which for the most part inhabit the seabeach between the upper and the lower level of the tide. Just about the limit of low water of high spring tides we should encounter a somewhat richer fauna and flora. In place of the bladderwrack we should find Laminaria; blennies, bogies, and other small fish, together with the larger crustacea such as crabs and lobsters, hermit-crabs and prawns would replace the shore-fauna. Clams and scallops would also 
ROMANCE OF DEPTHS OF THE SEA 93

be seen; while the molluscan whelks and horsemussels would still occur. Worms we should find crawling in and out of crevices and tubes in the sand, sea-urchins resting on the bottom, or :

"Lilting where the laver lingers

The starfish trips on all her fingers."

Encrusting organisms, such as hydrozoa and polyzoa, are here at work clothing rocks and stones, and shells of other animals with a rough and hirsute pellage. Here, too, will be found an abundance of brightly coloured sponges, while sea anemones - " those flowering stomachs " as George Meredith calls them-will be still as plentiful as in the rock-pools left behind.

The nature of this tract would of course vary with the bottom deposit. The fauna we have described in the main belong to a gravel and stone strewn floor. But much the same progressive change in the animal-life would be found if we set out on our journey along a rocky outspur running into the sea, with this difference: that limpets would be clinging and barnacles anchored to the rocks. Should we start, however, from a flat and sandy shore we should miss the large, sessile seaweeds and find instead numerous lug- 


\section{STUDIES IN INSECT LIFE, ETC.}

worms and many of the small crustacea such as the copepods. On the whole the sand supports a poorer fauna, though on the sand the Zostera, a vivid green, ribbon-like flowering-plant, gives its name to the next zone we traverse.

Walking further and further towards the depths of the Atlantic we should soon lose all sight of the algæ; and the shallow-water fish, the plaice and sole, whiting, skates, dog-fish and others, and cod, would give way to the megrim and the hake. The sea-floor would gradually change from rock or gravel or stones to sands, and ultimately to mud or oozes of various tints, their original colours often modified by the action of the decomposition of organic particles in them and on them. All these finer deposits are derived from the neighbouring land and are blown seaward by off-shore winds or washed down by rains and streams and carried out to the sea by rivers.

The distance to which fine matter in suspension may be carried is very great. The Congo is said to carry its characteristic mud as far out to sea as 600 miles, and the Ganges and the Indus as far as I,000 miles. Except in the neighbourhood of such great rivers a subaqueous traveller would soon pass beyond what Sir John Murray has 
ROMANCE OF DEPTHS OF THE SEA 95

called the "mud-line," a line that limits the terrigenous deposits everywhere surrounding dry land. Having reached this limit we must proceed warily, for at the mud-line, at an average depth of Ioo fathoms, we shall find ourselves at the edge of the continental shelf, that rim which extends seaward to a varying distance from all land areas, the rim on which Great Britain rests. Beyond lies the continental slope, a precipice more or less abrupt and more or less precipitate, descending by steep declines or terraced cliffs until depths of 2,000 fathoms are reached.

The deepest ocean-pit as yet sounded lies in the Pacific. It is $3 \mathrm{I}, 6 \mathrm{I}_{4}$ feet deep, thus surpassing by $2,6 \mathrm{I} 2$ feet the height to which Mount Everest rises above the mean ocean level. Roughly speaking, the heights to which the higher mountains rise above sea-level are paralleled by the depths to which the deepest " deeps" sink below that level. Yet, as has often been pointed out, these inequalities are negligible as compared with the diameter of the earth, and could we shrivel up our globe to the size of an orange, mountain ranges and abysmal depths would be no more prominent than the rugosities of the orange-skin. It may be added that if all the elevations on the 
earth were removed and filled into all the hollows we should have a world smooth as a billiard-ball and completely surrounded by an ocean I,450 fathoms deep. This is called the "mean sphere level."

The Atlantic has an average depth differing but little from the " mean sphere level." Compared with the other great oceans it has an unusually large area of comparatively shallow water. Of its total area $27 \cdot 5$ per cent. is covered by water less than $\mathrm{r}, 000$ fathoms deep: I8 per cent. lies between I,000 and 2,000 fathoms: and 47 per cent. between 2,000 and 3,000 fathoms; the remaining 7.5 per cent. is still deeper.

At the foot of the continental slope lies an illimitable plain, of a uniform dull, greyish-buff colour, flat and featureless as the desert, and only diversified by an occasional as yet uncovered rock or wreck or the straight line of a recently laid cable. This plain continues with hardly a change in scenery or in level until we approach the great mid-Atlantic ridge. As Bruce has shown, this ridge, which roughly bisects the Atlantic, extends from Iceland as far south as $53^{\circ}$ of south latitude, with a slight and quite inexplicable break just under the equator. The ridge runs almost parallel 
ROMANCE OF DEPTHS OF THE SEA 97

with the eastern contour of North and South America, which in turn, as the ordinary map will show, roughly corresponds with the western contour of Europe and Africa. From time to time the ridge rises above the surface of the water, as in the Azores group, St. Paul's Rocks, Ascension, Tristan da Cunha, and Gough Island.

Having ascended the eastern and descended the western slope of this mid-Atlantic ridge, we should again traverse plains of greyish ooze far more extensive than any level land tract known to geographers, and as we approached the American coast we should gradually pass through, in reverse order, the zones of life traversed when leaving Europe. On the eastern coast of America the slope is much more gradual than on the western coast of Southern Europe and Africa. Moreover, the terrigenous deposits of North America extend further to sea. This is mainly due to the fact that the winds of the North American coast are as a rule off-shore, whereas those of the Old World are mostly on-shore. It is common knowledge that our "weather" comes from the west. Here and there on the wearisome, monotonous scene we have mentally traversed would be seen halfimmersed in the ooze some yet uncovered rock 
or stone dropped by a passing iceberg, or a piece of pumice thrown out by some volcano, which after floating about on the surface for a time has become water-logged and dropped to the bottom; or, again, the wreckage of men's ships :

"The wrecks dissolve above us: their dust drops down from afar-

Down to the dark, to the utter dark, where the blind white sea-snakes are,"

or the bones and skeletons of whales and fishes and sea-birds lie awaiting burial by the ceaselessly falling Foraminifera. For if we examine a specimen of the ooze just described we shall find it consists of countless millions of small, microscopic, chalky shells, the innumerable homes of unnumbered unicellular animals, which, when alive, floated on the surface of the ocean.

The great mass of these belong to the group of Foraminifera, microscopic animals which have the power of secreting calcium carbonate from the sea-water and building it up into shells of many chambers. These shells compacted together form the white cliffs of our coasts and the chalk downs of our southern coasts. Foraminifera are capable of extraordinarily rapid reproduction, and at times the surface of the sea is almost packed with them. 
ROMANCE OF DEPTHS OF THE SEA 99

No less than 22,500,000 square miles of the Atlantic bed is covered with the shells of these organisms. Some twenty kinds have been classified. The commonest genus amongst them is the Globigerina, and hence the deposit itself is known as Globigerina ooze. At what rate the deposits thicken we do not know, but those whose business it is to lay marine cables have evidence that in some places about one inch is deposited in ten years. Like other unicellular, floating organisms, Foraminifera are kept floating whilst alive by the secretion of either air-bubbles or oil-globules lighter than water. When the animals die the floats cease to act and their bodies sink slowly down in a never-ceasing rain of marine dust, covering and obliterating inequalities on the ocean floor, and clothing the sea-bottom with a mantle of monotony.

These monotonous plains, which Kipling has called

"The great grey level plains of ooze,"

are as a rule at a depth of about 2,000 to 3,000 fathoms: only in a very few places does the Atlantic bottom sink over 3,000 fathoms below the level of the ocean surface. 
While the main area of the Atlantic is covered by the Globigerina ooze, there are a few small tracts off the western coast of northern Africa and around the Azores where this deposit is replaced by the shells of certain floating or pelagic molluscs known as Pteropods. Again there are comparatively large tracts, one forming a wide and irregular ring round the Bermudas, another an irregular patch to the west of the Canaries, in which Red Clay takes the place of Globigerina ooze. Red Clay is much more abundant in the Pacific ocean and is probably the most widely distributed of all deep-sea deposits. Usually of a reddish colour, at times it passes into a dark chocolate hue due to the presence of a number of small grains of pyroxide of manganese. As a rule Red Clay contains little or no calcareous shell matter, but flinty or siliceous organisms, spongespicules or the skeletons of Radiolaria or of Diatomes are often to be found in it. The most constant of its inorganic elements are pumice in all stages of disintegration, and oxides of iron and manganese nodules. These, either as minute granules or as secretions round other remains, not infrequently attain the size of marbles.

In certain circumstances, and if exposed for 
ROMANCE OF DEPTHS OF THE SEA IOI

long periods of time, the thin calcareous shells of the Foraminifera are soluble in sea-water, and thus it comes about that sinking through a depth of some 2,500 fathoms the Globigerina shells are dissolved and so never reach the bottom. In their place we find at depths, say below 3,000 fathoms, the bed of the sea covered either with volcanic material, or with flinty Radiolaria skeletons, or, still more rarely, with a Diatome ooze also siliceous. Like the Foraminifera, the Radiolaria are unicellular organisms buoyed up by floats of various kinds on the surface of the sea. But instead of secreting a skeleton of carbonate of lime, their skeleton is composed, like that of many sponges, of spicules of flint or silica. This substance is much less soluble in water than chalk, and consequently radiolarian ooze covers a considerable area of the sea bottom in the very deep waters of both the Pacific and Indian Oceans. The second siliceous deposit is distinguished by the predominance of the skeletons of the lowly forms of plant life, the Diatomes. This deposit is particularly associated with a band across the north of the Pacific and a great girdle round the Antarctic land.

In describing this imaginary journey across the 
ocean bed we have spoken of the things we should "see" ; but in reality we should see nothing at all unless we were gifted with the power of seeing in the uttermost darkness. At the bottom of the Atlantic a darkness prevails with which the blackest night on land would seem comparatively twilight. No ray of sun or moon can pierce through anything like 2,000 fathoms of water, and the only light ever seen at these great depths is due to the phosphorescence of certain of the deep-sea organisms. How far this phosphorescence is visible is still a matter about which we want more knowledge. We know that these luminiferous organs vary immensely in complexity and in power. Many of the lower lightgivers (Invertebrates) secrete a luminous mucus or slime, but others, especially the fish, have very highly organised luminiferous organs as complex as eyes, and these are segmentally situate, so that in walking across the ocean bed we should from time to time see a blurred glare at our feet, like an ineffective lamp in a London fog, and from time to time a fish would pass gleaming from prow to stern with rows of lights like a miniature liner with her port-holes all aglow.

The poet has told us that 
"The sun's perpendicular rays

Illumine the depths of the sea."

But the poet is only partially right; the sun's rays do not really reach the depths. Till the transatlantic voyage of the "Michael Sars," the limit to which light penetrated the ocean water was generally thought to be at about 300 fathoms. But Dr. Helland-Hansen, the Physical Oceanographer of the vessel, has devised a new and more perfect photometer than any that has hitherto been used at great depths. At its very first trial, near the Sargasso Sea, the apparatus acted perfectly. As far down as 500 fathoms the photometer registered light, and in considerable quantities; but at a depth of roughly 850 fathoms the most highly sensitive photographic plates were unaffected even after an exposure of two hours. Very sensitive pan-chromatic plates were used, and the result of the experiments made at noon on January 6th, I9Io, with a clear sky, show that a good deal of light penetrates " to a depth of I,000 metres-considerably deeper than was previously supposed." At 50 fathoms the rays were of all colours, though red rays were beginning to fade out; at this depth the red rays were in fact fewer in number than the green; blue and 
I04 STUDIES IN INSECT LIFE, ETC.

ultra-violet rays already predominated. At 250 fathoms the effect of the red and green rays was imperceptible even after a long exposure of plates especially prepared to register them. The ultraviolet and the blue rays are those which penetrate deepest. These records correspond closely with the observations of Hermann Foll in his diving expeditions in the Mediterranean. At a depth of I5 fathoms dark red animals looked to him quite black, whilst the green and blue-green algæ appeared lighter in colour. A coloured object of course looks black when untouched by rays of its own colour. In accord with this absence of red rays below 250 fathoms we find a very large number of crustacea, some of them of considerable size, and all of a most brilliant red colourscarlet as a boiled lobster-swimming about in the seas just below the lower limit of the penetration of the red rays. As a rule, however, in this region the fish are black in colour, though closely allied species of the same genus, variegated and light in hue, are swimming about in the upper waters.

Not only is there no light, but there is no sound at the bottom of the sea except for the rare explosion of a submarine volcano, and even when 
ROMANCE OF DEPTHS OF THE SEA I05

that occurs the noise must be somewhat muffled :

"There is no sound, no echo of sound, in the deserts of the deep."

Down there all is dark, and all is silent. It is also persistently cold. The temperature of even the surface waters of the sea varies comparatively little compared with the fluctuations of heat and cold on land. On land, temperatures as low as $-90^{\circ} \mathrm{C}$. and as high as $65^{\circ} \mathrm{C}$. have been registered, showing a range of $155^{\circ} \mathrm{C}$. At sea the range is only $33.8^{\circ} \mathrm{C}$., lying between $-2 \cdot 8^{\circ} \mathrm{C}$. and $3 \mathrm{I}^{\circ} \mathrm{C}$. As a rule at the bottom of the deep sea there is a uniform low temperature. Whether in the Tropics or in the Polar regions the bottom of the ocean registers a temperature of between $2^{\circ} \mathrm{C}$. and zero, though in many places it falls below the freezing point of fresh water.

These cold waters are, further, very still; at the bottom of the ocean there is a great calm. The waves that churn the surface overhead are unfelt at the depth of a few fathoms; even the great surface currents which stream along the upper waters of the ocean are hardly perceptible below some 200 fathoms. There are of courseas the wear and tear of cables teach us-places where deep-sea currents are strong; but on the 
I06 STUDIES IN INSECT LIFE, ETC.

whole the abysses of the sea are cold, noiseless, and motionless. The monotony of the surroundings is increased by the fact that no diurnal or seasonal change reaches those great depths. Summer and winter, spring and autumn, are to them unknown; for them there is no such thing as night and day, seed-time or harvest. Probably the inhabitants of these abysses breed all the year round, as land-forms do in the tropics. In the tropics with their uniform temperature we find insects and other animals showing no seasonal change of life, eggs, larvæ, chrysalises, imagoes all existing at one and the same time.

Deep-sea animals live at a tremendous pressure. Every five fathoms we descend in the sea the pressure increases by one atmosphere, and at a depth of 3,000 fathoms the pressure on each square inch of the body of an animal amounts to three tons, whereas at the surface of the waters it is about fifteen pounds. So great is this pressure that unless special precautions are taken the glass of the thermometers which measure the bottom temperatures is crushed to powder.

It used to be thought that the depths of the sea were uninhabitable, and then again it was thought that could we explore them they would 
ROMANCE OF DEPTHS OF THE SEA IO7

reveal animals known hitherto only as fossils, or perhaps indeed some strange creatures which would come into no class or subdivision of our modern zoological classifications. Neither of these conjectures has proved to be correct. The bottom of the sea is fairly well populated, and, with one or two not very striking exceptions, its exploration has revealed no persistent fossil-types and certainly no forms which do not readily fall into existing zoological systems. But the conditions which we have attempted to depict undoubtedly have had a great influence on the structure of the deep-sea animals. Many of them have retained and others have acquired a radial symmetry, and, planted as many of them are in the semi-fluid ooze exposed to a ceaseless shower of Foraminifera, they have acquired a certain "stalkiness." This "stalkiness" is shown by many of the cœlenterates and the sponges, by tunicates, and above all by the stalked sea-lilies. Animals with legs and tentacles have in the depths developed longer legs and longer tentacles. In fact the tentacles are many times the length of the body, and stretch out through the water in all directions, acting in the place of eyes. In the fishes certain of the fin-rays are prolonged and, like the barbels 
I08. STUDIES IN INSECT LIFE, ETC.

and tentacles, act as sensitive outposts. Many deep-sea animals have become sightless; others, as they approach the bottom, develop larger and more efficient eyes, sometimes standing out from their heads like binoculars, or even borne on the ends of stalks, as is the case in some of the eightarmed cephalopods (squids), and the larvæ of certain fishes.

Many of the fish are black, and what is more remarkable, they are dark inside as well as out. The cavity of the mouth and that of the body are alike lined by tissues of the blackest hue. Others are almost transparent, and indeed one can easily read print through the body of a Leptocephalus, the larva of the common eel; which is so transparent that one would not be able to see it in a dish but for the presence of the pigment in its eyes. But these larvæ pass up to the surface at a very early stage, and their transparency may be due to the fact that they are destined to a surface life. Many other forms are, however, very gorgeously coloured, and yet as far as we know "their glory is concealed," for there is no light and often no eye to note the brilliant bluesthe oranges, the greens and reds, the violets and purples-which deck their bodies. Perhaps it 
may be connected with the temperature at which they live that they show a marked inability to secrete calcareous skeletons: the bones of deepsea fishes are curiously soft and their scales thin. Their bodies, or muscles, have lost the usual elasticity, and when one pinches a hake, as when one pinches a patient suffering from beri-beri, the mark of the finger and thumb persists. Even the deep-sea sea-urchins present but a soft skeleton, and the carapace of the crustacea becomes chitinous, even the shells of the mollusca thin and translucent. Calcareous sponges have not been found in the depths. The exact reason for this deficiency in the power of depositing lime is obscure. It is certainly not due to a lack of material dissolved in the surrounding waters; but it is curious to remark that animals with a flinty skeleton seem to show an increased power of secreting silica in deep-sea waters. Another unexplained peculiarity of deep-sea animals is their tendency to reduce the size of their breathing apparatus. The gills are reduced in number and in size, and in some cases have almost disappeared. There is also a great tendency amongst deep-sea organisms to produce spines and processes-a fact which is recorded over and over again in the 
specific names which systematists have applied to deep-sea forms.

One of the most novel experiments carried on by the "Michael Sars" was measuring, at varying depths, the actual velocity and strength of the current which passes in and out of the Straits of Gibraltar. By the use of Ekman's Currentmeter, Dr. Helland-Hansen was enabled to add very largely to our knowledge of the rate at which the upper water sweeps eastward from the Atlantic into the Mediterranean, and the deeper waters sweep west. Hourly variations were very marked, and at times even the upper current went westwards. These variations appear to coincide with certain tidal movements.

Another remarkable feature of the Atlantic cruise was the number of nets and trawls the "Michael Sars" was able to keep out at once. Sometimes as many as seven or eight or even ten were dragging through the water at different levels, on the same line. In this way very large collections were made at certain determined horizons, and these have now been or are being worked out and will be published in full under the auspices of the Bergen Museum. It is interesting to note that the "Michael Sars" in its numerous dredg- 
ings found that the contents of the nets were, on the whole, practically identical in character when the nets were set at constant depths. Down to 75 fathoms there were small colourless fish of many species, fish eggs of many sizes, and larval eels in several stages of growth. These were accompanied by a series of transparent invertebrates of the usual pelagic type. From I50 down to 250 fathoms small silvery fish with telescopic eyes, beautiful to look at but feeble swimmers, drifting hither and thither in the waters, were taken. But perhaps the most numerous of all fishes was a grey Cyclothone; and here too were found a number of red crustacea. Between 500 fathoms and 1,000 fathoms the grey Cyclothone was replaced by a completely black but closely allied species; red prawns were still in abundance, and, what is more remarkable, red Chætognaths and red Nemertines, and there were also numerous species of black fishes and many dark brown medusæ. In these deeper hauls many animals of great rarity were taken : for instance, the little-known Cephalopod Spirula and a species of Melanocetus, the type of which was only discovered the other day in the Indian Ocean. Other fish were also taken which had 
hitherto been found only in the Indian or Pacific Oceans.

One of the triumphs of this expedition was to extend still further the brilliant researches of the Dane, Schmidt, into the obscure life-history of the common eel, supported as they had been by certain finds of the Irish Fishery Board. The "Michael Sars" captured younger stages of the larva (Leptocephalus) than had hitherto been taken; in fact specimens between one and two centimetres in length. These were found south of the Azores, and Hjort says he presumes "that this peculiar distribution can only be explained by supposing that the eel spawns south of the Azores and that the eggs and larvæ pass through their early stages there, being later carried into the North Atlantic and towards the coast of northern Europe by the Gulf Stream."

Although as a general rule the deep-sea forms tend to run rather small, there are exceptions to this, especially in the Polar regions. There we find certain Isopod Crustacea, represented on land by the wood-louse and on our shores by small forms barely an inch long, growing to the size of crayfish or lobsters; while very large pteropods, a group of floating mollusca, which 
ROMANCE OF DEPTHS OF THE SEA II3

at the surface seldom surpass an inch or two in length, have at great depths been taken over two feet long. Again, a remarkable Appendicularia, usually quite tiny, attains at great depths five inches in length with a noto-chord as big as a lamprey's. Many of these larger forms are found in the Polar areas, and not only within the Arctic and Antarctic circles do the deep-sea forms surpass their shallow-water relatives in size, but the bottom fauna in these areas is peculiarly rich both in the number of species and in the number of specimens.

Animals which live at the sea-bottom, or on the shore or at moderate depths on the continental shelf, so long as they are embedded in the ooze, or attached to stones or burrowing in the mud, or lying on the ground with feeble or no power of locomotion, are known to students of the sea as Benthos. Another category of animals, and a very important one, is the Plankton. The Plankton comprises all animals that drift. They may have organs of locomotion, but their powers of movement are entirely insignificant compared with the currents which sweep them along. Few of the smaller ones, swimming as hard as they can, progress more than a few inches a day, and 
II4 STUDIES IN INSECT LIFE, ETC.

yet, in comparison with their bulk, their locomotor organs are really moving them along as fast as the legs of a cantering pony. Planktonic animals are, however, readily moved by the waves, by the wind, by the tide, but they have little control over their translocation. Now a great deal of the Plankton is confined to the surface of the sea, and here if we examine the fauna we shall find innumerable animals of very various kinds. We have first of all a large part of the Plankton consisting of such organism as Sagitta, many marine worms, tunicates, small crustacea such as copepods-some of them as brilliant in coloration and design as any firework-many jelly-fishes, certain molluscs, and a few fish. But most important of all the members of the permanent Plankton are the protozoa and the minute algæ which swarm on the surface of the sea.

These algæ are the source of all life in the sea. They alone are capable, in the sunlight, of building up organic compounds out of the inorganic matter around them, and on them the whole of the marine fauna, from whales and the largest fishes to the microscopic, unicellular protozoa, whether floating on the surface or living in 


\section{ROMANCE OF DEPTHS OF THE SEA II5}

the abyss, ultimately depend for their food supply.

Then we have a second group of surface Plankton which is composed of the larval-stages of fishes, molluscs, star-fishes, sea-urchins, crustacea, worms, and many other groups. No matter where these animals lay their eggs, their larvæ as a rule float to the surface of the water and there drift hither and thither in incredible numbers. When one recalls the fact that the Rightwhale (Balaena), often fifty feet long, and one of the largest agglomerations of flesh-or protoplasm-is nurtured on the drifting floating organisms, one appreciates the fact that the Plankton forms indeed a very large feature in the life of the sea.

One of the most interesting contributions that the "Michael Sars" has made to our knowledge of this surface fauna is by Dr. Gran. He is responsible for a comprehensive chapter on the Phyto-plankton or the drifting plant-life of the sea. Careful microscopic examination of the bottom of the sea revealed a long time ago certain calcareous rods and plates known as rhabdospheres and coccospheres, little calcareous bodies belonging to microscopic organisms. Systema- 
II6 STUDIES IN INSECT LIFE, ETC.

tically these skeletons belonged to organisms on the border-line between animals and plants, and these organisms are so minute that they are only occasionally caught by the finest-meshed nets that sweep the surface of the sea. So minute are they, that to separate them from the seawater we have to use either an ultra-fine filter or an apparatus known as the centrifuge, which, whirling round at a great rate, is able to drive the solid matter suspended in the water to the furthest limits of the bottom of two rotating test-tubes. In the "Science of the Sea" it is stated that " only the waters of the Mediterranean have been investigated for these forms by methods other than the ordinary tow-nets: it would be of great interest to discover their distribution in oceanic waters generally." This Dr. Gran has done.

On the "Challenger" Sir John Murray used to obtain these microscopic creatures, now known as the Coccolithophoridæ, by allowing a glass of sea-water to stand for some hours, when the organisms sank and attached themselves to fine threads placed at the bottom of the tumbler. As we have seen on more than one occasion, organisms of the minutest size have been also discovered by examining Nature's own filter, the 
ROMANCE OF DEPTHS OF THE SEA II7

pharynx or stomach of the Salps which float about in the surface waters. The Coccolithophoridæ appear to be abundant in the open ocean of the tropical and sub-tropical waters, but they become rare at temperatures below $45^{\circ} \mathrm{F}$. They exhibit a great variety of external forms. And, as Dr. Gran writes, notwithstanding their small dimensions these microscopic calcareous creatures occupy a very important place in the economy of the sea, and their shields of lime, which may be met with in geological depths dating as far back as the Cambrian period, show that they have retained their shape practically unaltered through immeasurable ages.

They are almost entirely oceanic and mostly belong to the warmer seas. In coastal waters, where the salinity is lower, they are scarcer, but the commonest species, the little Pontosphara huxleyi, has been found even in the Baltic, and there in such immense quantities (five to six million organisms per litre) that the calcareous cells with their strong refraction gave a milky appearance to the waters of the inner parts of the Christiania fiords during the hot summer of IgII. Dr. Gran carried on his investigations on these forms from the Canaries to Newfoundland 
and thence across to the Irish coast, and as a result he came to the conclusion that these very minute organisms, which pass with ease through the meshes of the finest silk nets, are far more abundant than any others in the open sea, whilst the larger Diatomes and the Peridineæ appear comparatively scanty in numbers although rich in species.

Dr. Gran made a very careful investigation as to the depths to which the surface algæ sink, the algæ which are the ultimate food supply for all the fauna of the sea. Samples were regularly taken from the surface and at depths of Io, 25, 37 $\frac{1}{2}$, and 50 fathoms below the sea level. At depths greater than 50 fathoms algal life was extremely scanty. The maximum algal life appears to lie somewhere about 25 fathoms, which corresponds with what Lohmann had found to be the case with the Mediterranean Coccolithophoridæ. This further corresponds with Schimper's observations made in the Antarctic during the "Valdivia" expedition. He found that the maximum of algal life lay between 20 and 30 fathoms, that it totally disappeared below Ioo fathoms, and that the great bulk lay above the 50-fathom level. 
ROMANCE OF DEPTHS OF THE SEA II9

It has been observed by Hansen that plants in the sea are often so rare that it is difficult to understand how the animals can get enough nourishment, and yet the green, and as a rule microscopic, algæ have to produce enough food to support every single marine animal from the surface down to the deepest abyss. Hansen worked largely with vertical tow-nets, through whose meshes these minute Coccolithophoridæ passed with ease. But taking everything into consideration, one would not feel very happy about one's food supply if one were a marine animal, and thoroughly understood the economics of the ocean. The margin would strike one as very small.

Lohmann has studied, with the greatest minuteness and care, the quantities of all the Plankton organisms in. Kiel Bay throughout a year, and he has calculated the volume of the various groups in the Plankton in the different water masses of this area at all seasons. In the winter months the algæ seem easily outnumbered by the animals, and from December to February they scarcely form a third of the total Plankton, the floating and drifting living organisms. In the summer months, however, they preponderate 
and make up sometimes as much as 75 per cent. of the total. He calculates that the plants on an average make up 56 per cent. and the animals 44 per cent. of the total drifting organisms in these regions-really not a very large margin of safety for animals.

It should perhaps be mentioned that much of this floating Plankton is, like the abysmal fauna, highly phosphorescent and is indeed the phosphorescence with which we are all familiar. It was surface phosphorescence that the ever-observant Pepys noticed when he described the " strange nature of the sea-water on a dark night that it seemed like fire upon every stroke of the oar."

Between the floating Plankton on the surface and the inert Benthos at the base of the ocean, be it shallow or deep, are a number of actively swimming organisms-mostly fish, but also cuttlefish, whales, seals, dolphins and porpoises, crustacea, a few worms and medusæ, and a certain number of members of less well-known groups. These forms are capable of swimming strongly and making headway against effective currents or tides and are collectively known as NEKTON. They not only traverse wide stretches of water in the same horizon, but they are capable of de- 
ROMANCE OF DEPTHS OF THE SEA I2I

scending and ascending vertically, and no doubt at times many of them form substantial additions to the larder of the animals living at the bottom.

During a recent meeting of the British Association, which was held at Dundee, a discussion took place about life and the origin of life. Many learned professors expressed their opinions, but nobody seemed very successful in defining life. As far as one who was not there can 'form an opinion from the reports of the discussions, most of the authorities "came out by that same door wherein they went."

It is not easy to define life-in fact, it has not yet been done. We can only describe life by enumerating the attributes of living matter, and there is one attribute which is rather apt to be overlooked and may have been overlooked at Dundee. This is rhythm. Living matter is rhythmic. From the contractile vatuole of the amœba to the heart of man there is a definite repetition of action at more or less definite intervals, and there is, as Mr. Johnstone has so ably pointed out in his "Life in the Sea," a rhythm in the ocean.

There is a rhythm of the tide, a rhythm which corresponds with the rise and fall about twice 
every twenty-four hours, and that is involved in a still bigger fortnightly rhythm corresponding with the full and the new moon; for about halfway between these two phases the tide rises more slowly and to a lower height; and again, just as there is a half-daily and a half-monthly rhythm, so we have a half-yearly rhythm in the vernal and autumnal equinoxes. So regular are these rhythms that the tide is calculated years in advance, for all parts of the world, and navigators rely trustfully on these calculations, which are not found wanting.

This rhythmical change has impressed itself upon many marine organisms. As Mr. Johnstone reminds us, to keep cockles healthy in aquaria under artificial conditions one must run the water off the tank at least once a day so as to simulate a low tide. Convoluta - a small and lowly wormwhich lives on the sand and burrows beneath it when the tide is ebbing off the beach, kept in a laboratory in vessels of sea-water, periodically burrows under the artificial sand at the bottom of the vessel when the real tide is normally going out. The phosphorescence of the surface organisms which we have noticed above only comes into play at best some time after sunset. If 
ROMANCE OF DEPTHS OF THE SEA I23

these surface organisms capable of producing phosphorescence be kept in an aquarium in a dark room the same remains true. Although they are exposed to no secular change of light and darkness, they only show their lights at a time when the outside world is dark. The same is true, as Gamble and Keble have shown, with the chamæleon-shrimp, which in the sea shows a variety of protective colouring during the daytime but at night becomes a transparent blue. Hence it is obvious that the tide has produced.an effect which is lasting on certain organisms even when they have been removed from their natural surroundings and from the tidal influence for considerable periods.

Then again we have a rhythmical change of temperature, which is fairly constant for given places in the sea. About February and March the sea is at its coldest, but it gradually warms up until in August it attains its highest normal temperature. Of course in all these rhythms there are many disturbing features, such as the weather. But these can fairly easily be discounted. Just as we have an annual rise and fall of temperature, so do we have a daily one, the temperature being at its lowest about sun- 
I24 STUDIES IN INSECT LIFE, ETC.

rise, and gradually rising till about the middle of the afternoon. And again, there is a fortnightly rhythm, inasmuch as near the land the sea is warmer in the summer just after the time of new or full moon, and colder at the same periods during the winter.

Other rhythms might be pointed out, such as those dependent on the intensity of sunlight, and on the degree of salinity, which in turn depends to a very large extent on the water circulation of the sea. The pulsing-up of the Gulf Stream is the direct result of this circulation and affects not only the warmth but the salinity of the waters on our western shores. "The water is saltest when the drift is strongest, in the months of February to June, and is less salt when the drift is weakest, in the months of November to February." All these features have a profound influence on the life of the ocean; and a remote influence on land animals whose ancestry was marine. 


\section{Chapter VI}

\section{SEA FISHERIES *}

THE industry we have to do with is an enormous one. It is estimated that at the present time there are over 27,000 vessels manned by more than 90,000 seamen fishing from the ports of Great Britain. They land over 900,000 tons of fish, worth some $£$ I0,000,000, during the year. In the course of a single day they bring ashore some 3,000 tons of fish, and sell it for some $£ 33,000$. These tons of food material (except the fish destined for curing) are rapidly distributed throughout the country, as rapidly eaten, and next day the process is repeated. In addition to the actual fishermen who remove the fish from the sea, a great multitude of salesmen, packers,

* A considerable portion of this Address appeared in the Quarterly Review for January, I907, and is now reprinted from the "Proceedings of the Association of Economic Biologists," August, I907. The work here recorded extended over the first four and a half of the Marine Biological Association's work on the North Sea. 
curers, coopers, hawkers, ice-manufacturers, etc., are employed (for instance, out of the 20,000 hands employed in the Shetland herring fishing last summer, II,000 have been at sea, and 9,I20 have been employed on shore, of whom 7,560 were women), not to mention the large number of railway employees who are engaged in the transfer of a very perishable article. Anyone who has visited Lowestoft during the herring season must have been impressed by the number of Scotch women, amounting to some thousands, which come South in special trains to gut the fish.

The capital invested in steamers, sailing-boats and gear of all kinds is estimated at more than $£ I I, 000,000$. The fishing industry is further of great importance to the country as a training ground for sailors and marine engineers, and it affords a means of livelihood to a vigorous and independent population.

Like any other industry, sea-fishing is liable to arbitrary fluctuations. For instance, there was a partial failure in the herring fishery in Igo6 on the North and North-East of the Shetlands. The total number of crans landed being 438,950, as against 632,000 the year before, a record one, and some of the Shetlanders have been hard 
put to it to live. Such a failure sets those whose livelihood is threatened, thinking. The fishermen seek a sign, usually an obvious one, and in the present case the bad season was attributed to the presence of certain Norwegian whaling companies, which a few years ago established themselves in the Shetlands, and are vigorously destroying all the whales they can find in the neighbouring seas. These are killed for their blubber, the flesh is made into sausages, which go to make up the deficiency of meat then so widely felt in central Europe, and the bones are ground up and used as manure. It is, however, doubtful if the whaling is responsible for the scarcity of the herrings.

According to the evidence collected by $\mathrm{Mr}$. Donald Crawford's Committee on this subject in 1904 it would appear that practically the only point on which the fishermen were then agreed was that the spouting of the whales was often a good guide as to the position of the herring shoals. But the whales do not bring the herrings. It is probable that the general migrations and shoaling habits of the herrings are far more dependent on the physical character of the water, a relation which is particularly clear, as the International 
Investigations have already shown, in areas where sharply contrasted ocean currents are constantly striving for the mastery, as they are in the neighbourhood of the Shetland Isles. The Gulf Stream could more justly be abused for the comparative failure of the Shetland fishery in 1906 than the Norwegian whalers, whose operations have probably done no more injury to the herring fishery than they did in I905 or the year before.

I propose to confine myself in this article mainly to the North Sea, and from another point of view mainly to the English fishing authorities as opposed to the Scottish and Irish. The fundamental and central question to be settled is whether there is diminution in the fish generally or in any particular species of food-fish in the North Sea area-by far the most productive of our fishing grounds. If the answer is affirmative, the further questions arise-What is the cause of this diminution? and, How can it be arrested ?

In I863 Professor Huxley, Mr. J. Caird, and Mr. G. Shaw Lefevre were constituted a Royal Commission to inquire (I) whether or not the value of the fisheries was increasing, stationary, or decreasing; (2) whether or not the existing methods of fishing did permanent harm to the 
fishing grounds; and (3) whether or not the existing legislation was necessary. Three years later the Commission reported, and their Report forms an important mile-stone on the road of English Fishery administration. In the words of a most competent critic, " No such exhaustive report has since appeared, and in none that I am aware of are the conclusions deduced so courageous or uncompromising."

Since I866 great progress has been made in our knowledge of the life-history of food-fishes, yet even to-day we are hardly in a position to answer the questions set to Mr. Huxley and his colleagues. At that time nothing was known about the eggs or spawn of the food-fishes. Even while the Commission was sitting, in 1864, Professor G. O. Sars for the first time discovered and described the floating ova of the cod, and succeeded in artificially fertilising the same and rearing the young. Since that date we have found out the eggs of all the valuable food-fish, and artificially hatched most of them. But the facts about the cod's eggs appear to have been unknown to the Commission. They had to rely upon such data as the return of fish carried by the railway companies, the current prices of tish 
in the market, the return on the capital invested, and the impressions of the leading merchants and fishermen. They had little scientific knowledge of sea-fisheries to guide them, for the knowledge scarcely existed, and they had no reliable statistics. Nevertheless they arrived at very definite conclusions, as was usually the case when Professor Huxley was involved, and conclusions which subsequent writers have felt to be, for the time when they were formulated, sound ones. There was no doubt that during the early 'sixties, both in Scotland and England, the fisheries were improving, the number and the value of the fish landed at our fishing ports were annually increasing; the capital invested in the industry yielded a satisfactory return.

It was a time when the free-trade movement was at its height, and whether influenced or not by this economic doctrine the Commissioners reported in the most free-trade manner. The Commissioners strongly opposed the bounty system, which had done so much to build up the herring fisheries in Scotland. This, it is true, had been done away with in 1830, but it had been succeeded by, to the Commissioners, the almost equally objectionable syst $3 m$ of brand- 
ing herrings. They recommended the policy of opening the ports and the territorial waters to foreign seamen. They regarded the sea as free to all, just as the International Congress of Lawyers has lately declared the air to be. They found no reason to believe the supply of fish was diminishing. They were aware of the enormous destruction, especially in immature fish, consequent upon the methods of fishing, but regarded this destruction as infinitesimal compared with what normally goes on in nature, and held that it did no permanent harm to the fisheries. They recommended that all laws regulating fishing in the open seas be repealed. The Sea-fisheries Act of 1868 carried these recommendations into effect, and rendered it possible for a fisherman to earn his living "how, when, and where he pleased."

But since I868 much has changed. Beamtrawls continued to be increasingly used up till I893, since which date they have been replaced in steam-trawlers by the more powerful ottertrawl. There has been an immense increase in the employment of steam vessels, as is shown in the figures for the ten years $1883-1892$. In the former year the number of steamers was 225 , 
with a tonnage of 6,654 ; in the latter year the steam-ships numbered 627 , and had a tonnage of $28,27 \mathrm{I}$. The introduction of the use of ice, which took place about I850, and the invention of various methods of renewing and aerating the water in the fish-tanks, enabled the boats to remain longer on the fishing ground, and to waste less time voyaging to and fro to the port where the fish is landed. Further, the time spent on the grounds has been appreciably lengthened by the employment of " carriers," which collect the fish from the fleet of trawlers and carry it to port. There has been a great growth in dock and other accommodation. Since 1852, when the Manchester, Sheffield, and Lincolnshire Railway Co. opened their new docks at Grimsby, the accommodation has. steadily grown, until it now* covers I00 acres; the population, which sixty-five years ago was under 4,000, now* exceeds 60,000. In I854 the Railway Company despatched 453 tons of fish; forty years later they were handling 80, I34 tons, besides an export trade which, however, has not expanded in like ratio. The Great Eastern Railway in October, I906, opened a new dock at Lowestoft. New 
curing establishments have been set up along the East coast, new methods of curing have been devised, new kinds of fish have been cured. For instance, in the first part of the last century the haddock, upon which the steam trawler now so largely depends, was seldom brought ashore, only the largest occasionally reached the market. The introduction of haddock curing at Hull about I840 changed all that.

With the tendency to use larger vessels and more complex machinery came the tendency to form companies and syndicates. The fisherman ceased to own the fishing boat, and now retains at best a share in it. At the present time "by far the greater number of vessels are in the hands of companies or large private owners, and the hands engaged in working them are simply the servants of the owner." There are those at present who anticipate the formation of a great fish monopoly in the form of a combine or trust. The fisherman at the same time became more specialised as the.work became more complicated. The old fishing community, whose fathers and whose grandfathers before them have been fishers, is disappearing. The fishing village is turning into the cheap seaside resort. 
The scene of operations of the North Sea fishermen is by no means limited to the area in the map over which the two words wander. Roughly, for purposes of definition, we may say that a North Sea fisherman is one who lands his fish at an Eastern port. The fishing grounds of East Coast trawlers now range from Iceland and the White Sea to the coasts of Portugal and Morocco. In these directions the pioneers have been the codmen and the "liners," which catch their fish on hooks attached to long lines-sometimes seven miles in length, carrying 7,000 hooks -which are lowered to near the bottom and attached to buoys.

Professor Huxley's Commission of 1863 held the view that not only were as good fish in the sea as ever came out of it, but that there were as many, and as large, and that there was no reason to suppose their number would diminish. Indeed, when we consider that an unfertilised fish egg is rarely found in the sea, and that, according to Dr. Fulton, of the Fishery Board for Scotland, the female turbot produces annually $8,500,000$ eggs, the cod 4,500,000, the haddock 450,000 , the plaice 300,000 , the flounder $1,400,000$, the sole 570,000 , whilst the herring has to be 
content with the comparatively meagre total of $3 \mathrm{I}, 000$, there does indeed seem room for optimism. On the other hand, the reflection that if the stock of cod remains about constant, only two out of the $4,500,000$ ova attain maturity almost paralyses the imagination as to the destructive forces at work.

The eggs are expelled into water, whilst a male is "standing by," fertilised in the water, and, except in the case of the herring, whose eggs sink, those of the chief food fishes float to the surface, where they undergo the first stages of their development. Except in the case of the herring again, which has definitely localised spawning grounds, there has hitherto been little reliable evidence as to the existence either of stereotyped spawning migrations, or of very definite breeding grounds in the case of the chief food fishes. The great Lofoten cod fishery in spring is based on such a migration, as it is at this time of the year that the cod approach the coast in dense shoals for spawning purposes. During the summer, after the spawning is over, the cod disappears northwards. But with respect to the spawning habits of fishes in the waters most frequented by British fishermen we know 


\section{I36 STUDIES IN INSECT LIFE, ETC.}

little more than that the greater number spawn in relatively deep water, and at some distance from land. The brilliant discovery by the Danish investigators of immense numbers of the fry of the common eel in the deep water of the Atlantic,

a very long way south and west of Ireland, and the absence of the eggs and fry from the North Sea and Baltic, render it practically certain that the countless hordes of eels which leave the rivers of North-western Europe in autumn, migrate to the ocean for spawning purposes, and that the delicate young elvers, which enter the same streams in spring, have already overcome the perils of the long return migration.

Before considering the evidence for the existence of a progressive impoverishment of the fishery grounds, it is worth recording that the Trawling Commission of 1885 held that the increase of trawling had considerably affected the inshore waters, has led to a scarcity of fish in these waters, and that to get good catches it was necessary to go further to sea. Eight years later again the Select Committee of I893 held that " a considerable diminution (had) occurred among the more valuable classes of flat fish, especially among soles and plaice." Seven years later the Select 
Committee of I900 reported that "the subject of the diminution of the fish supply is a very pressing one, and that the situation is going from bad to worse."

The evidence which induced this change of view rests partly on experiment, partly on statistics. Although this view is possibly and even probably correct, none of the older sources of evidence is altogether satisfactory. One loss which used to be charged to the trawl, but of which it has been found not guilty, is that it destroyed the fish-spawn, but as we have seen the ova of all the prime food-fish float on the surface with the exception of those of the herring, and the herring is a fish that shows no sign of diminishing in number. In I886 the Scottish Fishery Board began experiments to determine whether or no the number and size of fish were diminishing on a certain limited area. The Firth of Forth and St. Andrew's Bay were closed against commercial trawling, and divided into stations. Once a month the ship employed by the Board visited each station and trawled over a given area. The fish taken were counted and measured. For the first few years the results indicated an increase of food-fish, but taking a 
longer period, and considering the flat fishes, we find that the numbers of plaice and lemon sole taken sank from 29,869 for the five years I885-90 to 28,044 for the five years I89I-95. On the other hand, the dabs, a comparatively worthless fish, had increased from 19,825 to 29,483 during the same two periods. These figures, it is true, have not been generally accepted as an exact measure of the changes which took place during the period investigated, but independent criticism has corroborated their general tendency.

In Norway elaborate experiments have been made to test the utility of fish hatcheries as a means of artificially increasing the supply of fish. For many years Captain Dannevig has carried on operations of this kind at his hatchery at Arendal, and there are many stories of English visitors to his establishment who have dined upon cod artificially hatched and reared in the Arendal tanks. The practice, however, at this and at other hatcheries has hitherto been to plant the fry out at sea immediately after hatching, and many experts have doubted whether such proceedings could materially influence the supply, since the cod, like other sea fish, is enormously prolific, and the ordinary fish hatchery cannot 
turn out more than two or three hundred million fry per annum, which is no more than the natural product of forty or fifty fair-sized fish. As part of their work under the international scheme, the Norwegians have investigated this problem by selecting four fjords along their south coast in proximity to the hatchery, and planting the fry in alternate fjords, leaving the intermediate fjords unsupplied. The relative abundance of young cod in the various fjords was then carefully investigated throughout the succeeding summer and autumn months. It was found that there was absolutely no relation between the abundance of young fish and the presence or absence of " artificial" fry. In I904, thirty-three million fry were planted in Söndele, and young fish were exceptionally abundant in the following autumn, but their abundance was equally striking in other fjords in which no fry had been planted, while in I905 all the fjords were deficient in young cod, whether they had been planted with fry from the hatchery or not. It would seem from these experiments that the remedy for the depletion of the North Sea fishing grounds will have to be sought elsewhere than in artificial hatching. 
The chief possible causes of an impoverishment of the sea are three. (I) As the great crops of the central United States exhausted the accumulated richness of a virgin soil, so when fishing began on the North Sea an accumulated wealth was drawn upon. When the Dogger and Iceland grounds were first opened up the plaice taken were bigger than has since been the case. The accumulated stock has been fished out. (2) Like a given area of land, so a given area of sea can support but a limited quantity of produce. There is a definite amount of food for fishes in a definite volume of sea, and so a limit is set to the number of fish in that volume of water. By use of the quantitative analysis introduced by Professor Hensen, he and Professor Brandt, of Kiel, have shown that a square metre of the Baltic produces an average of I50 grammes of dry organic material in the shape of diatoms, copepods, and other floating organisms. A similar area of land produces I8o grammes of ultimate food-substance. The productivity of the sea is then judged on this basis about 20 per cent. less than the land. Much caution, however, should be used in using these figures. (3) The excessive destruction of young fish is another, and perhaps the greatest, 
cause of the impoverishment of the sea. The destruction is enormous. In the winter of $1882-3$ it was estimated that in the Firth of Forth, the Firth of Tay, and the Moray Firth I43 millions of young herrings, and a much greater quantity of sprats were captured. They were mostly sold as manure. Yet the herring does not decrease ; it is the flat-fish that suffers most, the plaice and the sole.

In I896, 368 tons of small fish were seized by the Fishmongers' Company at Billingsgate; in I897, I43 tons. These were sold as manure or destroyed. In the Port of Grimsby, during the year April, I893, to March, I894, Holt estimates that whilst over seven million mature plaice were landed, over nine million plaice not sexually mature were brought to port; or, taking the trade distinction between "small" and "large" fish, six million odd plaice under $\mathrm{I} 3$ inches in length were landed, as opposed to nine million over I3 inches. As many as 10,407 young plaice have been taken from a single drag of a shrimp trawl. These are but a few instances, which might be indefinitely multiplied, of the great destruction which is going on amongst the young of our more valued food fishes. The questions they 
I42 STUDIES IN INSECT LIFE, ETC.

suggest are still a matter of debate. Whether even the destruction has an appreciable effect in the adult population of edible fish is even more debatable. It does not seem to have affected the herring, and we must never forget the prodigious number of offspring given to fish.

The taking of immature fish is not in itself uneconomic, unless by that means we so far reduce the total number that the adult stock begins to dwindle. Sardines are more valuable than their adult form, the pilchard; whitebait, mainly composed of young sprats, with I to 20 per cent. of young herrings, fetch more in the market than the parent form, and as long as the adults exist in sufficient number to keep up the stock of fry, sardine and whitebait fishing is perfectly legitimate.

I recently had occasion to lay before the Chancellor of the Exchequer a summary of the results that the Marine Biological Association, acting as Agents for the Government in the International Investigation of the North Sea, have attained since the summer of 1902.

The area which has been allotted to England is, roughly speaking, the south-western part of 
the North Sea, from the Dogger Bank to the Straits of Dover, together with the English Channel. For many years the Association was actively engaged in the investigation of many complicated problems connected with our food supply from the sea, with especial reference to those questions which were defined at the outset as of particular importance.

With regard to the work done and the promise it gives, it should be remembered that in June, I902, when the Association undertook the investigation, considerable changes had to be effected in the organisation of its resources in order to carry out the work. A staff had to be got together, a laboratory established, a steamer chartered. There were many difficulties to overcome, assistants had to be trained, methods of research devised, the seamen instructed, but all these troubles have one by one vanished, and at present the whole machinery is working smoothly and efficiently,

It is needless to dwell upon the importance of extending over a sufficient number of years the kind of investigation which the Marine Biological Association was making. Only so can the effects of secondary causes and exceptional fluctuations 
I44 STUDIES IN INSECT LIFE, ETC.

be eliminated from the essential, primary, normal factors. While time advances in an arithmetical progression so does the value of our results increase in a geometrical ratio. Over and over again has legislation been suggested on an erroneous estimate of causes, and the story of the fishery legislation of the country is the story of a house built on sand.1

In attempting to give a short résumé of the work the Association has accomplished, for the sake of clearness, and because it has furnished the problems of most pressing importance, I will confine my remarks chiefly to the plaice. What the sole is to the wealthy the plaice is to the poor. The fried-fish shops of our meaner streets supply little but plaice. The fish-eating poor will have it, and so exacting are they that if there be an absence of plaice on the market the fish-frier will buy more expensive, and what we think finer fish, such as turbot, but what goes into the back of the shop as turbot is sold over the counter as plaice.

During the last four years much hard work has been devoted to tracing the life-history and the distribution of this species throughout the North Sea, and I think the following important facts may claim to be, in the main, correct : 
(I) We have firmly established what had been anticipated from previous but more limited observations that the young fry of plaice are reared only in the shallowest fringe of coastal waters, and in far greater numbers along the continental than along the English side of the North Sea.

(2) We have located important spawning grounds in the most southern bight of the North Sea, have traced the special migrations of both sexes to these grounds on the advent of the spawning season, and have watched the course of their return migration to the feeding grounds in spring.

(3) We have determined the distribution of the various sizes of plaice over a large part of the North Sea, and can give clear indications of the sizes which may be taken in different areas at different seasons of the year, together with the relative frequency of the various classes in each area.

(4) We have determined the rate of growth of plaice from year to year, can now give a close approximation to their weight and length at all ages, and can follow the steady off-shore migrations of each yearly group during the years of adolescence. 
I46 STUDIES IN INSECT LIFE, ETC.

(5) We have found that the sexes of the plaice have a different rate of growth, a different size and age on attaining reproductive maturity, a different rate of mortality, as well as differences in their distribution and in the extent and range of their migrations. Starting life in approximately equal numbers, the females outnumber the males by about three to one when seven years old, and by about ten to one above that age. The majority do not attain maturity until between five and six years of age in the case of females, and between four and five years of age in the case of males. At different times of the year the sexes segregate and are unequally subject to the liability of capture by the fishermen.

The bearings of such facts as these on the diagnosis and treatment of the problems of over-fishing are too manifest to require elaboration.

(6) We have investigated the feeding habits of the plaice, and the extent to which their growth is dependent upon the temperature of the surrounding sea and the character of the sea bottom.

(7) By experiments on the transplantation of young plaice from their nurseries in the coastal waters on to the rich food ground of the Dogger 
Bank-a journey which would take the unaided fish several years to make alone-we have shown that their growth can be greatly hastened. There is little doubt that the annual weight of the plaice harvest from the North Sea could be considerably increased by artificial redistribution.

(8) I have considered at some length what we have been able to discover by means of our steam trawler about the plaice. Similar investigations have been carried on, but not yet so thoroughly, into the life histories, the distribution, the migrations and rate of growth of many of the other food fishes, the cod, the haddock, the sole, the turbot, and others. A complete register of the catch of the large commercial trawl has been kept each time the trawl has been shot, that is, up to the present date, just about I,000 times. Some quarter of a million measurements of fish other than plaice have been made by our naturalists at sea, and we are surely gaining a detailed and reliable knowledge concerning the general features of the fish population of different fishing grounds, and the size and weight of the average fish at each period of its age.

(9) We have further made a number of special 
I48 STUDIES IN INSECT LIFE, ETC.

experiments on the "Huxley" to determine the vitality and the extent of injury inflicted upon trawl-caught fish by the operations of trawling. These experiments are still unfinished, but we can at least say that trawling under commercial conditions on the grounds where the young flat fish lie is very fatal to young plaice, which are so injured by the crushing in the trawl that if returned to sea they do not live, and that the beam trawl is not quite so injurious as the otter trawl.

(I0) The hydrographic observations and the investigations into the minute organisms which crowd the surface of the waters, and which form the ultimate food of fish, have been efficiently carried on in accordance with the programme laid down by the International Conferences. In this work especially, the Plymouth steamer the "Oithona" has supplemented and helped the "Huxley" on the North Sea by making systematic and periodic investigations into the salinity, temperature, etc., of the waters of the English Channel, and in conjunction with the work of other countries we are now in a position to speak very definitely as to the manner in which the North Sea is supplied with ocean 
water from the Atlantic, both from the Northwest and through the English Channel. We further believe that it will shortly be possible to correlate the changes in volume of these two streams (with the fish food contained in them) with the climatic conditions of Europe and America. The curious ebb and flow of the Gulf Stream, its welling up and subsidence, closely connected as these seem to be with the migration of the herring, cod and haddock shoals in different areas, has also received much attention.

(II) We have investigated the character of the sea bottom with great care, and can now form as it were a geological map of an important part of the North Sea. Connected with the nature of the sea bottom is the kind of animals, molluscs, crustacea, etc., which it supports, and which in their turn serve as food for fishes. All these we have collected and identified, and we have carried on a most extensive series of experiments into the food of many different species of fish in varying localities, and in the interrelation of one species with another either as prey, competitors or enemies.

(I2) Amongst the most interesting of our results is the mapping out of the bottom currents 


\section{I50 STUDIES IN INSECT LIFE, ETC.}

which slowly set towards the east. From the mouth of the Thames to the Skager Rak we have traced the flow of these deeper waters during the various seasons of the year. These currents undoubtedly influence the distribution of the bottom living fish, especially in their younger and less active stages. The researches into these bottom currents have been made by bottles carefully weighted so that they trail along the bottom of the sea floating, say, a foot or eighteen inches off the ground.

(I3) Last, but not least, we have now an absolute measure of the intensity of trawling in the North Sea. The above-mentioned trailing bottles have been refished to a really astounding extent. Commercial trawlers have retaken them at the rate of 54 per cent. per annum. In one area 85 out of 390 of these bottles were recovered in six weeks, in another 50 out of 270 were trawled in five weeks, representing a local intensity of fishing, which, if continued, would give us between 80 and 90 per cent. of recaptures in a year. Marked fish yield closely similar results. When we reflect on the chances of their dying or losing their labels or being overlooked and not returned to the Laboratory, 
it is surely a most remarkable fact, full of significance to the practical man, that in the North Sea marked plaice of marketable size are recaptured at a rate of between 30 and 40 per cent. a year. Such facts indicate the intensity of the fishing in our area. It would seem that each square yard of the fishing grounds is swept by the trawl not once but again and again each year.

It is said that there is as good fish in the sea as ever came out of it, but undoubtedly they are most difficult to catch, and we have to go further afield, to the White Sea and the coast of Morocco to take them. We at present take our fish where we find them, as the savage lives upon the uncultivated fruits of the ground. Fishermen are like these improvident cultivators of virgin soil who make no return to the land for what they take from it. Statistics of our North Sea fisheries are far from reassuring as regards this important source of the national food supply. It has long been held by fishermen and experts that these grounds were showing signs of exhaustion, and the latest report to the Board of Agriculture and Fisheries bears out this view with some disquieting figures. The 
I52 STUDIES IN INSECT LIFE, ETC.

quantity landed on the East Coast of England from the North Sea (s. str.) by steam trawlers last year was 500,000 cwts. less than in r904, in which year it was also 500,000 cwts. less than in I903. The decrease is shown to be almost entirely in cod, haddock, and plaice, and works out at something like $£ 300,000$ 's worth per annum. We may be as surely exhausting our fish supply as the farmers of the middle west are said to have exhausted the virgin fertility of the plains, and the world could not be fed if on land men sought their food with as little forethought and system as the fishermen cast their nets into the sea.

Grave as the North Sea problem undoubtedly is, it is equally certain that the condition of the fishing industry generally was never more prosperous than at the present time. Thus, although the total fish landed in Scotland in I905 showed a decrease of 9I,5I9 cwt., the value showed an increase of $£ 4 I 8,046$, the average price per cwt. being 6s. 9d.,' as compared with $5 \mathrm{~s}$. $7 \frac{1}{4} \mathrm{~d}$. in 1904 .

Interference of some kind, whether by legislation, transplantation, or artificial culture, or by some combination of all these means, seems ultimately to be inevitable. But if we are to 
interfere with the fishing industry more successfully than our predecessors, should we not take advantage of the present time of prosperity to increase our knowledge on every side-scientific, statistical, experimental-so as to be able to act with conviction when the whole circumstances are clearer, and the adequacy of our proposals is less open to doubt ?

Moreover, in view of the growing interest of other countries, especially Germany and Holland, in deep-sea trawling, and of the international character of the most critical problems, can there be any two opinions as to the desirability of continuing investigations which have already been productive of very promising results?

Before, in conclusion, we turn our attention to the various bodies which administer and investigate the fisheries of England, a short consideration of what is done in the two great countries which have scientifically developed their fisheries may be profitable. In Germany we have the Kiel Kommission, and in the United States the Commission of Fish and Fisheries.

The Kiel Kommission exists for the scientific investigation of the German seas. It was established in I870, at the suggestion of a German 
I54 STUDIES IN INSECT LIFE, ETC.

sea-fishery society, an interesting example of the belief the German layman has in science. It consists of Professor Hensen, representing Physiology, Professor Karl Brandt, representing Zoology, Professor Reinke, representing Botany, and Professor Krümmel, representing Geography, all of whom occupy chairs at Kiel University, and of Dr. Heincke, Director of the Biological Station at Heligoland. Ar annual grant of $£ 7,500$ is made by the German Government for the maintenance of the laboratories at Kiel, the cost of steamers for investigations, the cost of the handsome reports published under the name of Wissenschaftliche Meeresuntersuchungen, and for - salaries, the sum allotted to salaries of the five members of the Commission divide but $£ 270$ between them. The Commission form a valuable body to consult when any extended exploration of the sea is in contemplation, and special grants are from time to time made by the Government for such purposes as the exploration by S.M.S. "Pomerania" of the Baltic and North Seas in I87I-2, the "Plankton Expedition" in the North Sea and Atlantic in I889, the "Valdivia" deep-sea expedition in I89o, the Antarctic expedition of the "Gauss" in 
I90I, and the German share of the North Sea International Investigation, which is still going on.

The want of some such body of trained men of science to advise and control was greatly felt in England in the initial stages of our own Antarctic " Discovery." The German Government have also spent considerable sums on the Biological Station in Heligoland, and make it an annual allowance of about $£ \mathrm{I}, 000$.

Every member of the "Kommission" is an active researcher into one or other of the innumerable unsolved problems of the seas. They are in close contact and constant communication with one another; they have the widest liberty of action, and investigate what they think most useful, and not what others consider most practical; finally, they have the great encouragement of their recommendation being not unfrequently adopted by those who frame and administer the fishery laws.

The American Commission, like the Kiel " Kommission," is not an administrative body, but concerns itself with the acquisition and application of knowledge concerning fisheries; like it, too, it is independent of official control. It reports directly to Congress. It was established 
I56 STUDIES IN INSECT LIFE, ETC.

about the same time, in $187 x$. Its work is, however, of a more practical kind; besides general scientific investigation, it collects fishery statistics and undertakes commercial fishery inquiries, assists in finding markets, and generally advises the trade and the legislature when diplomatic action is indicated; finally it is by far the most energetic fish-breeding institution in the world. Much of its work is concerned with the vast system of island waters-rivers and lakes-which traverse the Continent. The work has been carried on on a scale unknown elsewhere, and Congress has supported it with ample funds. The appropriation in $1897-98$ exceeded $£ 97,000$, of which $£ 4 \mathrm{I}, 000$ was spent on salaries, $£ I 6,000$ on scientific investigations and upkeep of steamers, $£ 37,000$ on fish-culture (mostly fresh-water) and $£ 3,000$ on administration and statistics. Besides this central body, many of the States possess Fish Commissions of their own. The Commissioners control numerous laboratories and fish hatcheries, two sea-going vessels, and many railway cars especially designed for the transport of fish-fry. The hatching is carried on on a very large scale ; six years ago I,I64 millions of young fish were hatched 
and shot into the waters of the United States, most of them were fresh-water, but this total includes 265 million cod, 87 million flat-fish, and 77 million young lobsters. Unfortunately no very critical analysis has been made of the fate of these young fry when they gain the sea, but the American is an optimist, and points proudly to his undoubted success in establishing his favourite shad on the shores of the Pacific from ova reared on the Atlantic seaboard.

Before leaving this branch of the subject it is only right to draw attention to the numerous reports and bulletins issued by the Commission. They form an invaluable array of memoirs, dealing not only with fishery subjects, but with general biological problems and with systematic zoology.

Space does not permit our dealing with the Scottish or the Irish Boards; the former has existed for a century, and being independent of departmental control, provided with a moderate income and the advice of such a series of zoologists as Goodsir, Allman, Sir John Murray, Professor Cossar Ewart, Professor W. C. McIntosh -who has done more than anyone in the Empire to elucidate the life-histories of marine fishes- 
I58 STUDIES IN INSECT LIFE, ETC.

and Professor D'Arcy Thompson, C.B., together with an able staff, the Fishery Board for Scotland has done much thorough and useful work. The fisheries of Ireland suffered from the economic disasters which overtook Ireland during the middle of the nineteenth century, and reached perhaps its lowest ebb in I89o. The revival in industry, with which the name of Sir Horace Plunkett is so indissolubly connected, has included in its scope the Irish fisheries. The fishery branch of the Department of Agriculture and Technical Instruction receives an annual grant of $£$ ro,000, and under the guidance of the Rev. S. Green and Mr. E. W. L. Holt, is already doing much to promote the fishing of the well-stocked Irish seas.

The English official fishery staff seems to have sprung from the recommendations of the Salmon Fishery Act of I86I. To carry out the regulations over fresh-water fisheries recommended by that Act, two Inspectors were appointed, and these were at first attached to the Home Office; a further Act in I886 transferred these Inspectors to the Board of Trade, and extended their duties so as to include the preparation of Annual Reports on Sea-fisheries 
In I903 another change took place, and the Inspectors were transferred to the Board of Agriculture, which now became the Board of Agriculture and Fisheries.

At present* the Central Staff consists of an Assistant Secretary and two Inspectors, in addition to a staff of statistical experts. Their duties are manifold, and far too many for so small a staff. We have seen that their birth was in a Salmon Bill, and much of their time is taken up with the comparatively unimportant fresh-water fisheries, and these form the subject of a separate Report. "Without actually administering the bye-laws of the local committees, they exercise a certain supervision over their actions. They have to attend numerous inquiries all over the country, prepare annual reports, and are responsible for the collection of the statistics which have recently assumed so extensive a development. Besides the central authorities at the Board of Agriculture and Fisheries, there are Local Fisheries Committees

* With the taking over of the work of the Marine Biological Association by the Government, and with the arrival of Mr. Runciman as President of the Board of Agriculture and Fisheries, the staff has been strengthened and increased. 
established by an Act in I888, a period when local government was much to the fore. These committees can be established by the county and borough councils on application to the Board of Agriculture and Fisheries, which defines the area over which the committee shall have jurisdiction. One half of the committee is chosen by the local councils and one half by the central authority. The necessary money is raised by a local rate. The committee may draft bye-laws, but these only become operative if confirmed by the Board. These bye-laws differ in different parts of England as the conditions differ. They deal largely with restrictions of trawling, in fact no steam trawler is allowed to trawl within the three-mile limit around the coast of England, and off the Northumbrian coast even the sailing-trawler is forbidden. They also deal with the sizes of the meshes of nets for shrimping, crabbing, etc.

On the whole the local committees, with the exception of one or two, cannot be regarded as a great success. They have power to collect statistics, but the money with which to do so has not been forthcoming; they have no power to spend money upon investigation, except so 
far as such investigation deals with stocking a shell-fishery, and their influence upon scientific research in fishery questions has been negligible. In many cases the committees control too small an area, and are able to raise too small an income to be effective. Where they have amalgamated, as is the case in Lancashire, Cheshire, and many of the sea-coast counties of Wales, they have been more successful.

Neither the central authorities, whose chief function is to adminster the law and collect statistics, nor the local committees, where, as we have seen, the power of spending money is limited to the "shell fisheries"-and stretch the Act to the breaking point you cannot make a flat-fish into a shell-fish-have either the time or the money for extensive scientific experiment. This has to a large extent been left to local or private enterprise, and is in the main confined to four centres, the Northumberland coast, the Lancashire and Western district, and the Channel and North Sea. The first-named area has recently been supplied by a private benefactor with funds for an efficient laboratory, situated at Cullercoats, from which it may be expected that much useful work will ensue. 
It is a little difficult to disentangle the Lancashire and Western Sea-fishery Committee from Liverpool University on the one hand, and from the Liverpool Marine Biological Committee or Society on the other. The Committee owns a handsome marine station at Port Erin, on the southern end of the Isle of Man, where, together with the fish hatchery at Peel in Cumberland, the largest fish-breeding experiments in England are carried out. In I904, 5,000,000 young plaice were reared and shot in the sea from Port Erin alone. The Committee publishes Annual Reports ; volumes, of which five or six are already published, on the "Fauna and Flora of Liverpool Bay," and a valuable series of "Memoirs" of great use to students. It is probably owing to this Committee that the University owes its connection with the local sea-fisheries authorities. In the laboratories and museums of the University the scientific work of the local districts is carried on by officials paid by the Fisheries Committee, and special rooms in the handsome new Zoological Department have been assigned to these two organisations. The greatest common measure between the three bodies is the Professor of Zoology, Dr. Herdman, who is the 
Honorary Director of the scientific work, and to whose untiring energy the University and the district owe so large a debt. With him work two senior assistants, Dr. Jenkins and Mr. James Johnstone, from whose lucid and admirable work many of our figures and facts have been taken.

The third and last body occupied with original research in the seas is the Marine Biological Association of the United Kingdom. It is the most important of these institutions, and aims at a national rather than at a local activity. The fine laboratory which dominates the eastern end of Plymouth Hoe was erected at a cost of $£$ I2,000, and opened in I888. The objects of the Association are to "promote researches leading to the improvement of zoological and botanical science, and to an increase of our knowledge as regards the food, life-conditions and habits of British food-fisheries and molluscs." Although a high average of scientific work has been maintained in the published memoirs connected with the Plymouth Laboratory, great attention has been paid to matters of practical interest. In a list of some $35^{\circ}$ papers, published with the aid or under the auspices of the Association between I886 and I900, very nearly one-half deal with 
I64 STUDIES IN INSECT LIFE, ETC.

direct economic problems. From I892 to I895 the officers of the Association carried on very extensive investigations at Grimsby into the destruction of immature fish, and it is gratifying to find the recognition the Select Committee of I893" extended to the "facts and statistics" submitted by the Scotch Fishery Board and by the Association.

In the summer of I902, the Association, at the request of His Majesty's Government, undertook to carry out the English portion of the International Investigation of the North Sea. The scope of this enquiry is immense, and its importance to the largest fisheries available for our fishermen is incalculable. Some idea of the kind of work accomplished has been furnished in the preceding pages.

What now seems to be most required, in addition to the maintenance of the work already in progress, is a closer co-operation of these various bodies with one another, and with the central authority now established under the President of the Board of Agriculture and Fisheries.* The outlines of some such scheme seem plainly indicated by the existing constitution of these various

* This co-operation now happily exists. 
bodies. The Fisheries Department is responsible for administration, statistics, and general advice to the President of the Board on fishery matters.

The Marine Biological Association undertakes general investigations at sea of a national as distinct from a local character, as well as such local investigations and experiments as can conveniently be carried out at its laboratories. The Sea Fishery Committees need additional powers to enable them to carry out local scientific investigations more fully in their respective areas.

Perhaps an annual conference between the representatives and experts of these bodies and the officials of the Fishery Department for the express purpose of drawing up plans of work for the ensuing year would be the best means in the first instance of leading up to more intimate co-operation and organisation. 


\section{Chapter VII}

\section{SIR JOHN MURRAY : A GREAT OCEANOGRAPHER}

MAN, like most of the mammals, is essentially a land-living organism. His ancestry, "probably arboreal," was redolent of the soil. His prehistoric forerunners were as unaccustomed to commerce on the ocean as are to-day the anthropoid apes of Africa and the far East. But as far as recorded history goes back he had some traffic with the deep, and in more or less inadequate boats he skirted the fringes of islands and of continents. But any accurate and detailed knowledge of the nature and the contents of the waters upon which he floated, and of the solid rocks which underlie those waters, is an affair of yesterday, hardly half a century old.

At the time that Sir John Murray took up the investigation of the bottom of the ocean we knew less about the conditions of deep-sea life and the submerged soil which supports it than we do at 
the present moment about the conditions of the higher atmosphere. Then nearly everything about the surroundings of life in the abysses of the ocean and about the geology of the depths of the sea had to be learnt. Within the last few years man has learnt to dominate the lightest of the three elements which compose the globe, and the Renaissance of science, which is as notable in the reigns of Queen Victoria and her descendants as it was in the time of the Stewarts, is extending its results to the air, which until the development of petrol engines necessarily remained unconquered.

In the Stewart times British science led the world, and undoubtedly in the last fifty years British oceanography has done the same. The invention of the self-registering thermometer by Cavendish in the middle of the eighteenth century placed a new and essential instrument in the hands of those interested in the condition of the depths of the ocean. This thermometer was used in Lord Mulgrave's expedition to the Arctic seas in I773, and again in James Ross' Antarctic expedition (I839-I843), where the temperature of the water was constantly observed to depths of 2,000 fathoms. On this expedition, and on 
I68 STUDIES IN INSECT LIFE, ETC.

that of his uncle, Sir John Ross, to Baffin Bay, many classical soundings were made. Depths of over I,000 fathoms were plumbed in the Arctic, and for the first time it was realised that animals abounded at great depths in the ocean. Worms, crustacea, and "corallines" were found living on a substratum of gravel and clay. Places even of I,000 fathoms were dredged and yielded living creatures, and Sir John Ross's expedition for the first time demonstrated the existence of animal life at great depths of the ocean.

In the middle of the last century many expeditions, most of which were British or North American, were investigating the economics of the sea, but in nearly every case they had some commercial object and were not exclusively scientific. The invention of telegraphy and the possibility of telegraphic messages being conveyed by submarine cables made the problem of the deep a "financial proposition," as the Americans say. In surveying a possible route for a cable to the United States, Dr. Wallich, in I860, on board H.M.S. "Bulldog," traversed the Atlantic and was one of the first to appreciate the fact that plant life hardly exists in the sea below the 200-fathom line, and he further noticed 
that the bottom fauna, which is uncommonly varied and rich, lived upon the organisms which fall down from above. In the same year the telegraphic cable between Sardinia and the African coast broke. Fleeming Jenkin, who must have been Professor of Engineering at Edinburgh about the time Sir John Murray was a student and long afterwards, recovered part of the broken cable from a depth of 1,200 fathoms. With it sponges, worms, molluscs, and polyzoa were brought to the surface. This was regarded by Professor Allman as "having afforded the first absolute proof of the existence of highly organised animals living at a depth of upward of $\mathrm{I}, 000$ fathoms."

But the science of the depths of the sea and the science of oceanography were in these times inchoate. The first great expedition to investigate the physical, the chemical, the geological and the biological conditions of the great ocean basins were sent out in $I 872$ by the Government of this country, then under Mr. Gladstone, and in that year H.M.S. "Challenger" left England with a staff of scientific observers to traverse the salt waters of the globe. From that date until the present time no such complete and 
I70 STUDIES IN INSECT LIFE, ETC.

organised a staff of scientific observers, helped in every way by the naval officers (for it was an Admiralty expedition), has left any country for so prolonged and exhaustive investigation into the economics of the ocean. The "Challenger" Expedition set a standard-in fact it practically established a new science, a science of which Sir John Murray was, in a way, the arch-priest.

As the introduction to the narrative of "The Cruise of the "Challenger' " recites: "The vast ocean lay scientifically unexplored. All the efforts of the previous decade had been directed to the strips of water round the coast, and to enclosed or partly enclosed seas. Great things had certainly been done there, but certainly far greater things remained to be done beyond." This consideration led to the conception of the idea of a great exploring expedition which should circumnavigate the globe and if possible find out the conditions of life at the surface of the sea, at the intermediate depths, and also at the profound abysses of the ocean. Sir. John Murray's main interest in the expedition was at first physical and geological rather than biological, though he soon acquired a real knowledge of animals, at any rate in so far as they affected the problems which 
appealed more nearly to him. He was an adept at constructing machines and instruments which would plumb the secrets of the deep, and as soon as the results of his researches on the bottom of the sea had appeared he was recognised at once, and as long as he lived, as the authority on the floor of the ocean. This is no time or place to attempt to sum up Sir John Murray's contributions to our common knowledge. His theory of coral-reefs is probably right-in certain areasand so is the theory of Darwin. His merit here lies in that he shewed that Darwin's view is not universally applicable. The romance of Christmas Island must also be told elsewhere.

Sir John was no specialist. He had ever the widest point of view of the chemistry, the physics, the geology, and the biology of the ocean, and to him these varying sciences always had their full value in the problem which he had made his own. He was constantly devising new sounding apparatus for bringing up samples of the sea bottom, thermometers for testing the bottom temperatures, instruments for registering the pressure at great depths, and other implements which have made our knowledge of the depths of the sea accurate and even minute. 
Before we consider what really is at the bottom of the ocean, let us for a moment try to consider what we should see were it possible to "gather up the sea." Suppose we imagine that the sea "is gathered up," and that we start from the west coast of Portugal or Spain to walk or bicycle or motor across the -bed of the Atlantic Ocean. At first we should progress along a shallow incline, passing through a region "peopled" with sea-anemones, polychromatic worms, limpets, mussels, periwinkles, dog-whelks, star-fish, seaurchins and small crustacea, certain inshore fishes, and certain seaweeds. Proceeding ever west towards the depths of the Atlantic we should soon lose sight of the seaweeds, and the nature of the invertebrate fauna and of the fish would change. The sea-floor would cease to be rocky, gravelly, or stony, and change into soft muds or oozes of various colours. The constituents of these deposits are derived from the neighbouring land washed down by rivers and streams and carried out to sea by the fresh water. Sooner or later, however, we should pass beyond the line which earth-born deposits reach, and the limits of this area have been very aptly named by Sir John Murray " the mud line." This mud 
line lies somewhere about roo fathoms deep, and when we reach it we must proceed with the utmost caution. We are now at the edge of what Sir John named the "Continental Shelf," a rim which extends into the sea to varying distances around the great land areas, a rim indeed upon which our British Islands rest. Beyond this Continental Shelf lies the Continental Slope, something of a gentle mountain-side, but sometimes something of a precipice, which descends smoothly or in terraces until the depths. of the Atlantic at about 2,000 fathoms are reached. We are now on the bottom of the deep sea, and the bottom of the deep sea is a monotonous, flat, featureless greyish-buff expanse of uniform scenery: Kipling's "great grey level plain of ooze." We should traverse this featureless plain for more than 2,000 miles, crossing, somewhere about the middle, the mid-Atlantic Ridge before beginning to ascend the long low slope leading to the American land. Here we should pass through the same zones of living organisms that we traversed on the European side, but in a reversed order.

There are, however, pockets in the ocean, just as there are mountains on the land, and the 


\section{I74 STUDIES IN INSECT LIFE, ETC.}

depth of the pockets in the sea approximates to the height of the highest mountains on the land : roughly they correspond. The greatest depth yet recorded is 5,348 fathoms, and the sounding which registered this was taken east of the Philippines by the German steamer "Planet." It is a few feet more than six English miles. Oceanographically, the term " deep" applies to those parts of the ocean in which soundings of 3,000 fathoms or deeper have been taken. In the last map that Sir John Murray published there were fifty-seven "deeps," thirty-two of which lay in the Pacific and but few-two exceeding 4,000 fathoms-in the Atlantic. From the tide mark down to these depths more than half (in fact 58 per cent.) of the ocean lies between 2,000 and 3,000 fathoms, the average Atlantic depth. The Continental Shelf which fringes our islands and continents is really a marine extension of the neighbouring lands. Many portions of it were in fact dry land not so very many hundreds of thousands of years ago. This shelf is under the influence of tides and currents and the deeper waves, but beyond its edge no wave disturbs the conditions of life at the sea bottom. It is silent ld-bas, it is dark ; 
it is also confoundedly cold-never more than a degree or two above zero-and it is still.

The pressure under which animals live at great depths is enormous. At the surface of the ocean the pressure per square inch is fifteen pounds, at 3,000 fathoms it is three and a half tons. The change of pressure when deep-sea animals are hauled to the surface often distorts their shapes. Only occasionally the erosion of a marine cable demonstrates the presence of slow but persistent deep-sea currents; but for the most part all is still, motionless. The bottom of the sea, like the soil of the land, grows. It is added to by all sorts of mud carried from the land by rivers and winds; broken-off ends of glaciers-icebergs, carrying with them chunks of rocks-contribute larger particles. All these at any rate are terrigenous, and so are, as a rule, the products of volcanoes, which are constantly dispersing volcanic dust over large areas of the ocean. Pumice-stone of various kinds plays, at any rate in certain parts of the ocean, a conspicuous rule in the bottom deposits. A third source is extra-terrestrial, and meteorites of the interstellar space reach in very perceptible numbers the bottom of the sea.

But far the most bulky and widely distributed 
I76 STUDIES IN INSECT LIFE, ETC.

material which drops down from above are the skeletons or shells of innumerable organisms which live on the surface or a little below the surface of the ocean or on its margins :

"The wrecks dissolve above us; their dust drops down from afar-

Down to the dark, to the utter dark, where the blind white sea-snakes are."

Calcareous algæ, corals, molluscs, crustacea, skeletons of fishes and of seals and whales are perpetually falling on to the ocean bed like the "gentle rain from heaven," and nearer inland the shells of many of the shore-dwelling animals are ever being washed down to the depths.

Besides these, the ocean-bed consists of many substances which are regarded as chemical or secondary products. Certain kinds of clay arise from the decomposition of minerals on the sea floor, manganese nodules and greensand are examples. Further examples are the boulders and rock fragments which have been carried by icebergs far from the land where they originated, and these lie scattered over the sea bottom. All these varied materials are unequally scattered like patchwork over our ocean floor, and mixed with nearly all of them are sharks' teeth and 
whales' ear-bones in numbers which seem incredible. The terrigenous deposits naturally occur most abundantly, in the neighbourhood of the land which has produced them, for instance coral mud occurs only near coral islands. Both seals and penguins have been known to drop into the ocean fragments of rock very far away from the land where they originally picked them up.

Sir John Murray classified marine deposits into: I. Red-Clay. This, the most widely distributed of all deep-sea deposits, covers a very large portion of the deeper part of the ocean, especially in the Pacific. In Red Clay there were few if any remains of calcareous skeletons, but flinty spicules from the siliceous organisms such as sponge-spicules and Radiolarian skeletons may be detected. Sir John estimated that the Red Clay covers an area of about 5I,500,000 square miles of the bottom of the sea.

2. Radiolarian-OOzE. Then we have the Radiolarian-ooze, consisting of the flinty skeletons of unicellular animal organisms, which is characteristic of the deep tropical waters in the Pacific, and Indian Oceans. He estimated that the Radiolarian-ooze covers 2,290,000 square miles of the ocean's depths. 
3. Diatom-ooze consists of the small flinty skeletons of plants. Diatoms are unicellular lowly algæ; but lowly though they be, they are the ultimate food which keeps the inhabitants of the ocean going. Without diatoms there would be no marine fauna. It is estimated that these delicate and microscopic shells cover an area of nearly II,000,000 square miles of the bottom of the sea, chiefly in the Southern Seas.

4. Globigerina-ooze is a pallid, somewhat sticky, yellowish-grey, semi-liquid mud formed of the chalky skeletons of unicellular animals which swarm in the upper waters and never reach the deeper depths of the ocean, since they are dissolved if exposed too long a time to the action of salt water. But the bottom of the Atlantic is seldom more than 2,000 fathoms from the surface and forms "the great grey level plains of ooze" previously referred to. The great bulk of the Atlantic is floored by these skeletons, and Sir John Murray estimated that they cover an area of practically $50,000,000$ square miles, in all oceans.

5. Pteropod-ooze. A much smaller deposit is the Pteropod-ooze, which consists of a floor of shells of surface-living molluscs. This covers an 


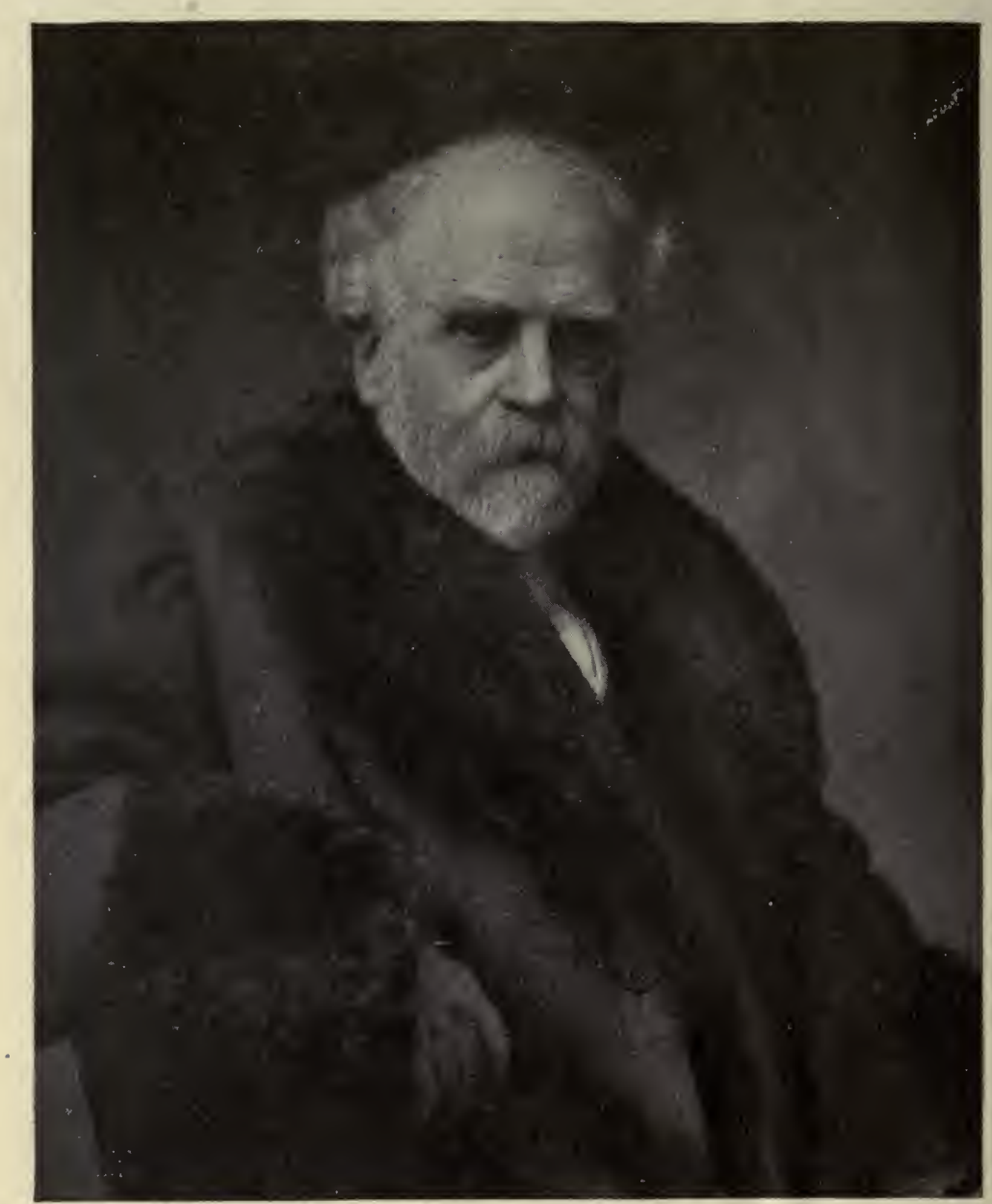

Elliott \& Fry, Photographers.

SIR JOHN MURRAY.

To face page 179. 
area of some 400,000 square miles, chiefly in the Atlantic.

To return for a moment to the terrigenous deposits, the particles that are washed down from the land naturally occur mainly in the neighbourhood of islands or continents, and consist of the fragments of minerals forming the continental rocks. These altogether cover an area of something like $20,000,000$ square miles. The great bulk of this is washed down from the earth, but the coral-mud which is formed by definite marine organisms must be separated from these, and also the volcanic mud which is vomited up from the earth's crust, or from submarine volcanoes, which are more common than the " man in the street" thinks.

The above very brief account of the floor of the ocean gives some idea of the sort of problem Sir John Murray devoted his life to solve. If it were possible, one would now like to give some sort of account of the man himself. $\mathrm{He}$ was born in Canada, but no one who ever met him would have mistaken him for anyone but a Scot, and indeed his ancestry was Scottish. His later school education was in Stirling, and he joined 
the Edinburgh University at a time when Edinburgh University had many students of very striking ability. He was always a great individualist, and he worked at the University at what interested him, and was quite happy in satisfying that interest without any thought of examinations or of a degree, although it was obvious he could have taken a degree in more than one subject. As an old examinatorial hand I feel grateful that I never had to examine Sir John, at any rate in a viva, which is still one of the glories of Edinburgh University. He would have been too much for any examiner.

He worked at literature with Masson, at anatomy with Goodsir and Turner, at chemistry with Crum Brown, at natural history with Allman, and was at least occasionally to be seen. at lectures in law and in theology; but the teacher who most powerfully influenced him was undoubtedly Professor Tait, in whose laboratory he worked for more than one session under the direction of William Robertson Smith and under the more or less direct inspiration of Clerk Maxwell and Sir William Thomson, afterwards Lord Kelvin.

In the late sixties, Professor Tait was at the 
height of his reputation as a teacher and investigator, working in close association with Sir William Thomson; and at that time W. Robertson-Smith, later the celebrated theologian and oriental scholar, was acting as assistant in his Physical Laboratory. Amongst the many pupils who afterwards achieved distinction in varying walks of life, who were studying in the laboratory under the Professor and Smith, were Sir John Jackson and the late Mr. Meik, builders of many of the world's ports and bridges. Murray and Robert Louis Stevenson, the latter then making his first and wholly unsuccessful effort towards a scientific career, were also among the small band. But " natural philosophy" bored Stevenson, and he used to manifest the greatest adroitness in drawing Robertson Smith from the arid deserts of physical science into the tangled thicket of theological discussion, and he always succeeded in keeping him there as long as he liked.

A little later the Edinburgh Evening Club was founded, and here, after the return of the "Challenger," Murray met a variety of friends, some of whom were about his own standing and others his seniors. The Club, the object of which was to have every conceivable subject repre- 
I82 STUDIES IN INSECT LIFE, ETC.

sented by at least one expert, flourished greatly in the late seventies. Legal talent was well to the fore in the persons of Lord Neaves, a man of high literary culture, Lord Gifford, whose memory is immortalised in the Natural Theology Lectureships he founded, and Lord Young, of whom it has been said that there were "few who did not fear and none who did not admire" his biting wit. Other members were Professor Blackie, eccentric, sensational, and somewhat bizarre, but withal a striking personality; Professor Masson, whose classes Murray had attended; Sir Daniel Macnee, President of the Scottish Academy, a brilliant raconteur; Robertson Smith, keen as a rapier and delighting in controversy; Thomas Stevenson, the father of the novelist-grim and resolute. Besides Smith, Dr. Davidson and Mr. Lindsay stood for the Free Church, and two other well-known Edinburgh figures at the time were in the Club-Mr. Alexander Gibson, the Advocate, and Sheriff Nicolson, a great singer of songs and teller of stories, who occasionally, like Silas Wegg, "dropped into poetry." J. F. M'Lennan, too, must not be forgotten, for then he was just coming into his own as an original and thoughtful writer on anthropological subjects. There were 
also Aeneas Mackay, Sheriff of Fife and Kinross, for some time Professor of Constitutional History in the University, with his stately mien and the humorous twinkle in his eye, and $\mathrm{Mr}$. J. Irvine Smith, small, neat, and exquisitely polite, artistic to the finger-tips. Amongst this company of brilliant men Murray spent many an evening at 90A, George Street, and no doubt held his own in conversation, for he had ever much to say and a remarkably clear voice with which to say it, a voice which stood him in good stead when presiding at home or abroad at conferences of scientific men. At the time of his death he was Presidentelect of the International Meteorological Congress to be held the following September at Edinburgh, and was actually engaged in making arrangements for a successful meeting the day before his tragic end.

Sir John was rather a short man, with broad, somewhat stooping shoulders. His eyes were blue and penetrating, and he had the light hair which so often goes with blue eyes. $\mathrm{He}$ had a very fine head, and indeed a noticeable figure in any company. He was a man of force and presence, and what Dr. Johnson said of Burke might as truly be said of Murray : 
I84 STUDIES IN INSECT LIFE, ETC.

"Yes, sir! if a man were to go by chance at the same time as Burke under a shed to shun a shower, he would say, "This is an extraordinary man!'"

He married rather late in life, in his forty-ninth year, and was a devoted husband and father. $\mathrm{He}$ held unconventional views on the education and the training of his children, but he took the keenest interest in the well-being of each of them, and was seldom away from one or other of them. Under a somewhat brusque exterior lay a kernel of genuine kindliness and even tenderness of heart.

In 1868 he was already visiting Spitzbergen and the Arctic regions as naturalist on board a whaler, but his great chance in life came when he joined, as one of the Natural History staff, the "Challenger," which from I872 to I876 was exploring the seas of the world.

It really was a chance for the scientific staff of the "Challenger" had been definitely selected and appointed, when almost at the last moment a vacancy occurred, and it was on Tait's urgent recommendation that Wyville Thomson gave the vacant post to Murray. Tait did not claim for his young friend that he was as yet a finished 
man of science, but dwelt upon his ability, his energy, his indomitable resolution, and the courage and coolness that would make him an invaluable stand-by in any emergency. Owing to the death of Sir Wyville Thomson soon after the return of the great expedition, Murray was appointed to edit the scientific results of the voyage. Sir John was never a man who could appreciate or tolerate the red tape of Government Offices, and hence, when in time the Treasury turned restive, he spent his own money in bringing out the last volumes of the Reports. He liked to have a hundred per cent. of his own way and very often got it; if not, he would, as a rule, withdraw from the enterprise. But he was extraordinarily kind and patient with quite a number of men whom he himself had trained and brought to the front in oceanographic research. Later in his career he became comparatively rich, and some of these riches he spent in promoting the subject to which he had devoted his life. He always rejoiced in hospitality, and his home, "Challenger" Lodge, was a centre of many interests. It pleased him from time to time to entertain at rather lavish dinners the members of a small Society in London, the "Challenger 
Society," whose common aim is marine research. He liked to feel he was helping forward research and bringing kindred interests together by entertaining us at one of his London Clubs, before the scientific Papers were presented, the reading of which was at times a little delayed by his abundant, cheer.

He never spared himself, and when he was approaching his seventieth birthday he embarked on the "Michael Sars," a steamer no bigger than an ordinary fishing trawler, with a gross tonnage of 226 and with but 300 h.p. engines, to cross the Atlantic on a scientific expedition the profoundly important results of which he published in collaboration with Dr. Johan Hjort in the wellknown book, "The Depths of the Ocean." He was very capable of getting on terms with the sailor-men, and had a thorough knowledge of the sailor's mode of life and the sailor's point of view, and, it may perhaps be mentioned, of the sailor's vocabulary. Although he became seventy-three a few days before the final tragedy, he seemed, and was in fact, a much younger man, "good for at least, another ten years" as a leading physician, who knew him well, remarked to me some weeks ago. 
It was not long after the completion of the "Challenger" volumes that he turned his attention to the Lake Survey of Scotland. During the earlier years he had the devoted assistance of Mr. Frederick Pullar, to whose memory the six volumes of the Survey, edited by Sir John and Mr. Laurence Pullar, were dedicated in Igro. This work on the fresh-water lochs of Scotland is classic. It has set a standard, and the inland waters of Scotland have been investigated and recorded in a way that the lakes of other countries have still to seek. The great variety of knowledge which Murray could bring to bear upon anything connected with the sea or the freshwater basins made him the leading authority on the waters of the earth.

After a great expedition like the "Challenger" some one múst necessarily receive honours from all learned societies and Governments, and as editor of the "Challenger Reports," Murray gathered honours in every direction. He received his K.C.B. in 1898 and during the same year he was appointed Knight of the Prussian Order "Pour le Mérite." The medals of learned Societies that were given him and the honorary degrees that were conferred upon him are too 
I88 STUDIES IN INSECT LIFE, ETC.

numerous to detail here. Every one of these was well deserved, but he himself always held that they were honours given to the expedition and not to the individual. 


\section{Chapter VIII \\ GROUSE DISEASE}

"THE longer I live, the more I am convinced that the apothecary is of more importance than Seneca; and that half the unhappiness in the world proceeds from little stoppages, from a duct choked up, from food pressing in the wrong place, from a vext duodenum, or an agitated pylorus."

Thus that incorrigible amateur-physician Sydney Smith wrote of our poor suffering humanity, and thus we can as truly write of the grouse. Little stoppages, food pressing in the wrong place, a vext duodenum, and an agitated blind-gut and there you have "Grouse disease"!

At the onset I must, however, protest against that fallacious and all-embracing expression. It will be difficult to get rid of, for the average keeper and sportsman is seldom clinically inclined and they see their birds diseased or dead or dying and they are grouse and he is content to put it all down to "grouse disease" and to leave 
Igo STUDIES IN INSECT LIFE, ETC.

it at that. But grouse suffer and die from many diseases. In a few dozen birds examined chiefly in Cambridge the following disorders were seen: Pleuro-pneumonia in a bird which had lived long in captivity; pericarditis ; necrotic changes in the liver; chronic diseases of the peritoneum; and a septic infection due to gangrene supervening upon a broken wing.

Sick and dying animals are apt to creep away into corners and hide themselves, thus it comes about that when these animals die patently and in large numbers, the public is apt to regard this mortality as due to some disorder peculiar to the animal in question, and the disease receives the name of the species which is afflicted. Hence we hear of such illnesses as "horse-sickness," " silk-worm disease," and " grouse disease."

The disorder which is usually associated with the too comprehensive expression "grouse disease" was investigated by Klein some eighteen years ago, and in this article it will be called Klein's grouse disease. Klein found in the tissues of the bodies of birds that had been dead for some time a certain bacterium, whose nature and life history he investigated. This bacterium is now recognised as one of 
the Bacillus coli group, a widely spread group of bacteria which are found universally in the alimentary tract and which rapidly invade the tissues of the body after death. At the time Klein was working bacteriology was comparatively a new subject, and this invasion by bacteria of the tissues at the time of and after death was not appreciated.

Klein's grouse disease was associated also with some congestion of the lungs; the windpipe was described as dark in colour; the airsacs contained blood; in the cavities of the lungs blood or some granular exudation occurred; the liver and kidneys were congested and soft; and there was an exudation on the peritoneum. We now, however, know that many, if not all, of these appearances in the chief organs of the body are but normal post mortem changes and occur sooner or later after death in birds which were perfectly healthy when killed. Another feature attributed to the Klein's grouse disease was that its onset was comparatively sudden, its course rapid, and according to all observers it attacked healthy and plump birds. The Grouse Disease Inquiry did not succeed in coming across any sick or dead birds which are plump or in 
good condition. All the grouse, and they amount in number to some twelve hundred, which have been investigated, have been weighed, and in every case where there has been any disease there has invariably been wasting; the sick birds are always thin, have lost flesh, and are in a poor condition. One final feature of Klein's grouse disease is its seasonal incidence; usually it is said to occur with greatest virulence in the spring, to die down during the summer, and to recur in a less virulent form in the autumn. To this seasonal variation I shall return.

Klein's grouse disease is still a matter of inquiry. During the five or six years whilst the Commission has been prosecuting its inquiries, this "disease" has frequently been reported, but on investigation the characteristics enumerated above have not been present; still, the sportsman and the gamekeeper, who do not weigh their grouse and seldom their evidence, and who are but imperfectly acquainted with post mortem changes, firmly believe in the existence of this "disease," and it may be that it really exists and that it is the misfortune of the Inquiry that in their researches the investigators have not come across it. 
If we now turn from what must seem rather negative criticism to the more positive results attained by the investigation of the Departmental Commission, we may begin by pointing out some of the difficulties which confronted the Inquiry.

In considering exceptions it is so immensely important to know the rule. In studying disease our starting-point should be the normal, the healthy; yet until lately no one has studied the healthy grouse, and indeed it is almost impossible to find a normal grouse, i.e., one free from parasites. A grouse cannot express to us its feelings; the state of its tongue, the rate of its pulse, even its temperature tell us nothing because we have no norm and no means of estimating the extent to which a diseased bird has departed from the standards of a healthy grouse. The nature of the numerous kinds of blood corpuscles, which alter in proportion so markedly in animals when they become parasitized, was but a few months ago quite unknown, the "blood count" uninvestigated; in fact, the Inquiry started, as regards the cause and symptoms of the diseases which affect grouse, practically at scratch. It was, of course, known that the suffering birds lose their activity and are 
I94 STUDIES IN INSECT LIFE, ETC.

more easily caught than healthy grouse; their flight is slow and limited in length ; they are said to seek water; the "call" becomes feeble and hoarse; the feathers of the back and throat lose their lustre and become ruffled; the eye is dimmed. But these external symptoms may be associated with several diseases and diagnostic of none. Nearly all of them occur in the two diseases Coccidiosis and Strongylosis which, according to the Inquiry; are responsible for a very large percentage of deaths among grouse.

Each of these diseases is caused by an animal parasite, and the investigation of the parasites attracted the attention of the scientific advisers of the Inquiry from an early date. I am afraid that in describing these organisms I shall have to use some rather long words; in extenuation I can only say, slightly altering Captain Kedgick's retort to Martin Chuzzlewit, "Well! I didn't fix the zoological language, and I can't unfix it, else I'd make it pleasant."

At the beginning of our Inquiry we knew two internal parasites of the grouse (endoparasites) and two or three parasites which live outside the skin (ectoparasites). At the present time we know that grouse, like other animals, 
have a considerable fauna living both in and on them. Grouse are in fact not birds, but in a small way aviating Zoological Gardens. The scientific members of the Inquiry have recorded nine different species of insect or mite living either amongst the feathers or on the skin of the bird or in other ways associated closely with the grouse, and no fewer than fifteen animal parasites living in the alimentary canal, the lungs, or other organs. Some of these are negligible. They either exist in too small.numbers or infest but a very. small percentage of birds; others, however, are found in about 95 per cent. of the cases investigated, and two at least are associated with grave disorders which often terminate in death.

The interest of the insects and mites which live on the skin of the bird is that they very likely form the second host of the tape-worms, which undoubtedly do a certain amount of harm to the lining of the alimentary canal. There are, for instance, a couple of genera of bird-lice, lively little creatures, which take cover amongst the small feathers-which, by the way, form their arid diet-like startled deer in the 
I96 STUDIES IN INSECT LIFE, ETC.

undergrowth of a forest. Few grouse are free from these bird-lice, perhaps hardly ro per cent., and the number on each bird is to some extent a measure of its ill-health. On a healthy grouse perhaps but two or three are found. They are insects with stout and powerful jaws, which they use to bite off the barbules of the feather or the finer plumules which form their sole nutriment. What fluid they obtain to moisten this somewhat dry nutriment is not apparent, but the animals are active and by no means so easy to catch as one at first thinks. They lay very beautiful eggs attached in small groups to the base of the after plume of the feather or between it and the main shaft. The young hatch out as miniatures of the parents, and there is no metamorphosis. The same species occurs on the Black Grouse and upon the Willow, or Hazel Grouse. On a piner these bird-lice increase enormously in number, and their numbers to some extent serve as a measure of the gravity of the disease. Both of these birdlice cast their skin several times; the exact number of times is, however, not known, but cast skins are frequently met with. The young birds are probably infected with these ecto- 
parasites whilst in the nests, the bird-lice falling from one bird to another when they are contiguous. They have also been known to cling to the grouse-fly, and in this manner may be transported to a new host. In no case was any specimen of either of these two genera found in the crop of the grouse.

Two fleas are found on grouse, one rare, but the other is a well-known bird-flea, which has also been found in the nest of the Hawfinch, the Dipper, the Blackbird, the Moorhen, and others. Since it is known that a certain dog-flea is the second host of one of the cestodes (tapeworm) of the dog, and a rat-flea of a tape-worm of the rat, it seems possible and even very probable that one of these fleas may be the intermediate host of one of the chief worms which infests the alimentary canal of the grouse. We have, however, not succeeded in finding the cysts, neither have we found specimens of the flea in the crop of the bird.

Then there is a tick, the common rice or dogtick, usually attached below the jaw of the bird or to the eyelid or to some other position where the beak cannot reach it. Ticks are responsible for the transference of a very fatal 
I98 STUDIES IN INSECT LIFE, ETC.

epizootic termed Spirillosis in fowls in the Sudan, and for numerous other diseases which afflict man and cattle throughout the world, but ticks are not common on the grouse, and the Inquiry has as yet traced no disease to them. In parts of Ross-shire, however, especially in certain woods, these ticks are said to be extremely numerous, and the keepers aver that they frequently kill off large numbers of black-game. They are commoner during the spring and early summer, but usually disappear at the beginning of July. Curiously enough a common cheese or flour mite was from time to time found in considerable numbers on the skin of the grouse, and apparently these mites sucked the blood of their host, for their alimentary canal contained red food.

Finally, there are a couple of true flies, the well-known grouse-fly which is apt to crawl up the sleeves of those who handle grouse in the early autumn. The grouse-fly belongs to the same group as the horse-fly and the sheeptick. The latter, however, has lost its wings, and burrows in the wool of the fleece. Most members of the family to which this grouse-fly belongs live upon birds; it particularly frequents 
swallows and other allied species. Recently Dr. Sharp has pointed out that the grouse-fly $(O$. lagopodis) is distinct from the ordinary birdfly (O. avicularia). The habits of the grousefly are difficult to investigate. It is believed to suck the blood of the grouse, and very probably inoculates the bird with some of the protozoa or minute animal parasites which infests its blood. The adult or imago burrows amongst the feathers of the bird, and anyone handling grouse during the late summer is apt to disturb a fly or two. Their feet, although large, are very beautiful. Each is provided with a pair of most powerful hooks. Altogether these insects have a sinister aspect, and they are very repellent to people who do not like flies. The grouse-fly occurs very frequently in larders where freshly killed grouse have been placed, and after a short time they readily leave their dead hosts and accumulate on the windows. Like the fatal Tsetse-fly of Africa, which conveys sleepingsickness, they lay no eggs, but produce one larva or maggot at a time, and this immediately turns into a pupa. The pupæ of the grouse-fly, usually found in the nest of the grouse during August and September, are black, shiny, seed- 
like-looking objects Probably each pupa takes some three-quarters of a year to develop into the adult fly, and the latter disappears from October until June. There is thus a certain tragedy in the life of these insects. No parent ever sees its offspring, no offspring ever knows parental care. We have never found one of these flies in the crop of the grouse, nor have we succeeded in finding cysts in the bodies of flies which were broken up, or teased up, or cut into sections and examined under the microscope.

Finally, there is another fly whose larva lives in grouse droppings. All these creatures have been carefully searched for the larva of the grouse tape-worms, but so far with no definite success.

Of the fifteen endoparasites but two or three demand attention; the others are comparatively rare or innocuous, and some, such as the gape-or forked-worm so fatal to pheasants, are not normally parasites of the grouse. Occasionally by some accident they get into the wrong Paradise.

These endoparasites, which live inside the body of the grouse, are responsible to some extent for the illnesses from which grouse suffer. 
Any attempt to control their number and their activity must depend on our knowledge of their life-history, hence the stress which has been laid on the external parasites which may act as the second or larval host of some of them.

At the time the recent Grouse Disease Inquiry commenced to inquire there were but two worms described as being in the alimentary canal of the grouse-the large tape-worm which lives in the small intestine all the year round, known to every sportsman, and a slender threadworm which inhabits the paired cæca, or blindguts, which are unusually large in the grouse and play a very important part in its digestion. The latter worm under certain conditions, and when present in considerable numbers, is associated with one of the two diseases which have especially attracted the attention of the Inquiry.

Davainea urogalli (Modeer).-Of the three tapeworms that are found in the grouse, this species is by far the largest and by far the most common. It exhibits little seasonal variation, and is found in considerable numbers all the year round. The birds become infected at an early age.

D. urogalli is normally found in the small intestine, though sometimes parts of it are found 
202 STUDIES IN INSECT LIFE, ETC.

in other portions of the alimentary canal. As

a rule, three or four individuals are met with. At other times, especially in weakly birds, there are dozens, and these fill up the lumen of the intestine to such an extent that it is difficult to see how food can pass along it.

D. urogalli, like most cestodes, produces a very great number of eggs at any one time. It may be, at a rough estimate, at least 100,000; but this figure is no measure of the reproductivity of the cestode, because as fast as new segments break off at one end, new ones are formed just behind the head, and the animal goes on producing new segments very much in the same way as a recurring decimal reproduces cyphers. Hence the eggs of this cestode must be scattered in countless millions all over the grouse moors. They are probably eaten by some insect or land mollusc, and in the body of these invertebrates, change into the "cysticercus" or larval stage.

The popular notion that grouse do not eat animal food is entirely wrong. For the first three weeks of the bird's life the greater part of its diet consists of insects or arachnids, and from the crop of the first grouse I ever dissected 
I took six Saw-fly larvæ, eight caterpillars of a Geometrid moth, one caterpillar of a smaller moth, two small Tineid moths, and a number of Hemipterous insects resembling the frog- or cuckoo-spit, a fly, two specimens of plant-lice, one small spider, and the remains of four slugs. The gizzard of the same animal contained, in a more broken-up condition, two or three dozen larva of saw-flies and moths, some young Hemipterous insects, and the pupa of two true flies.

In searching for the larval or cysticercus stage of these and the other cestodes, we have examined a considerable number of insects which occur commonly on grouse moors. We have also carefully searched the bodies of many freshwater crustacea which abound in the pools and tarns from which grouse drink. But hitherto our searches have met with no success. One specimen of cestode which infests the common fowl is said to have its second host in several species of the slug Limax, but we have not succeeded in finding cysts of either form of tapeworm in this slug.

But besides the large tape-worm (Davainea urogalli), which was described by Baird fiftyseven years ago and the thread-or round-worm 
(Trichostrongylus pergracills), described by Cobbold thirty-seven years ago, we have two other species of tape-worm and four other species of round-worm. One of the former is negligible, the other, the transparent tape-worm (Hymenolepis microps), is however to some extent associated with disease. These worms, like the larger species, may exist in incredible numbers in the duodenum or that part of the alimentary canal which comes just after the gizzard; yet they are quite invisible whilst alive. The contents of the alimentary canal in this region resemble a thick puree, which, on the addition of some fixing reagent, resolves itself into an inextricable tangle of fine threads, each representing a tape-worm. The heads of these worms are hidden away in the folds of the lining mucous membrane of the alimentary canal, and undoubtedly they do something to interfere with its continuity. A certain amount of inflammation is set up. We have no sure information as to the second host of this cestode, but as a general rule the cysts of the genus Hymenolepis live in some insect or centipede, as is shown by the fact that the adults exist in bats, insectivores, and insectivorous birds. Tape-worm cysts have 
recently been found in a flea by Professor Minchin, and these cysts have been shown by Mr. Nicoll to grow into Hymenolepis diminuta in the intestine of the rat. Hence the suggestion, first made by Dr. Leiper, that the fleas of the grouse may be the second host of $H$. microps is well worth following up.

It is curious to note that this tape-worm disappears during the winter months, a fact which may afford some hint as to its second host. The large tape-worms, on the other hand, remain all the year round and must be of quick growth, for they are found $35 \mathrm{cms}$. in length in a young grouse but three weeks old.

Three other round-worms have also been shown to exist in the grouse. One of these in the duodenum may prove of importance. This species (Trichosoma longicolle) is allied to a form which lives in the human appendix, and at times is the cause of appendicitis.

\section{Coccidiosis}

Beside the worms we have in the grouse seven distinct unicellular or protozoan parasites which live in the intestines or in the blood of the grouse. Most of these are uncommon and comparatively 
harmless, but one, a Coccidium (there is no more popular word for it), is the cause of disease in the grouse-chicks.

Since this disease was first found in the young grouse much has been written about it in the newspapers, and in nearly every case the writer has taken the Coccidium to be a Coccus. Now a Coccus is no more like a Coccidium than a crocus is like a crocodile. The Coccus is a bacterium, a vegetable, and it has a simple lifehistory; the Coccidium is a Protozoan, an animal with, as we shall see, a very complicated lifehistory.

Dealing first with the Coccidiosis :

One of the aims of grouse-preservers is to have numbers of healthy young grouse-chicks in order to produce stocks of strong birds. Bad seasons for grouse are partly due to epizootics among the young broods in the spring, and the chief cause of mortality among grouse-chicks is a small, one-celled microscopic animal parasite, Eimeria (Coccidium) avium. This parasite penetrates the lining membrane of the gut of the bird, and gradually destroys it, thereby setting up digestive troubles in the form of intestinal inflammation (enteritis), accompanied by acute 
diarrhœa, which usually terminates fatally. Grousechicks are most susceptible to coccidiosis during the first six weeks of their life, and if they can survive this period unattacked, they usually reach adult life.

The disease-we may call it Coccidiosis for short-caused by this species of Coccidium is brought about in this way. The grouse moor is simply peppered over with millions of oval cysts, or capsules, which represent the freeliving stage in the life-history of the Coccidium. Each cyst is very resistant to changes of temperature and moisture, and can live for a long time. The cysts pass with the food or the water or the grit into the alimentary canal of the bird, and in the duodenum the thick cyst wall is dissolved and four spores emerge. Now, when one reflects on the thousands of cysts which are at times taken up by the grouse, one can readily understand that the presence of these numerous spores boring into the epithelial cells ultimately destroys the lining of the duodenum, where in fact the most active digestive processes are carried on in the normal bird. Furthermore, the Coccidia multiply in the intestine, and the resulting progeny attack new regions of the 
alimentary tract, especially the cæca, which become swollen and inflamed. After a time some of them produce small forms (males), and others change into large forms (females); these two forms fuse, and the resulting stage is the cyst mentioned above, which, passing from the body, infects the whole moor. There are many details omitted in this short abstract of the complicated life-history of this parasite, which have been worked out in the grouse by Dr. Fantham at Cambridge; but enough has been said to show the nature of the disease, which is well known to occur in several other animals. There is a Coccidiosis of the rabbit, and a very fatal form attacks pigeons, fowls, and pheasants, and the grouse Coccidium if administered to chickens will set up the disease in fowls.

To repeat a little, for the life-history of this parasite is very complicated :-

The chief source of contamination on the moors is the droppings of other diseased grouse. The droppings contain thousands of cysts (oöcysts) or spores of the parasite, and these spores, with their hard coats, are extremely resistant, and can endure for very long periods without the death of their contents, which gradually divide 
to form four smaller spores inside. The spores are scattered over the moors by the action of the wind and rain, and, alighting on the heather or in the tarns of the moors, are taken up by the grouse in their food or drink. When the cysts are swallowed, they enter the gizzard of the bird and pass unchanged into the first part of the intestine, called the duodenum. Here the pancreatic juice is poured into the intestine, to aid in digestion, and under its influence the cyst-wall is softened and dissolved, and the four small spores (contained within the ripened spore or oöcyst) are set at liberty. Each small spore contains two active motile germs or sporozoites, which emerge from the softened spore-case, and proceed to penetrate the epithelium of the duodenum. The young parasites ultimately cause the destruction of the lining of the first part of the small intestine-the region where, normally, the most active digestive processes occur. The coccidium parasites multiply in the duodenal epithelium, and then invade the cæca or "blindguts," with disastrous results.

Sooner or later a limit is reached, on the one hand, to the power of the grouse-chick to provide nourishment for the parasites, and on the other 
hand to the multiplicative capacity of the parasites themselves. The Coccidium then begins to reproduce sexually. Many small male parasites are produced, together with larger food-containing female Coccidia. The male and female parasites conjugate and then encyst, bursting through into the cavity of the gut, and giving rise to the spores found in the cæcal droppings on the moors.

So far as the grouse-chick is concerned, the formation of Coccidian cysts means either recovery or death. If the infection of the parasites has been a heavy one, and multiplication of the parasite has proceeded apace, then the destruction of the intestinal epithelium has been so great that death of the grouse-chick results. If, on the other hand, the epithelium of the intestinal wall has not been too much destroyed-fewer Coccidian parasites having been present-then the gut-epithelium may slowly regenerate and the young bird gradually recover and improve in condition after the Coccidian spores have been passed out with the cæcal droppings.

As a rule, grouse are most susceptible to Coccidiosis during the first six weeks of their life, and if they can survive the dangers of this period they usually grow up. The chief external 
symptom of the disease is diarrhœa, the legs show weakness, and the feathers, especially around the legs, are in poor condition, flight is feeble, and the bird loses weight. Internally the alimentary canal is inflamed and digestion greatly impaired; perityphlitis is set up around the cæca, which becomes greatly enlarged. The blood corpuscles also undergo marked alteration, and an anæmic condition prevails. Further, the destruction of the lining wall of the alimentary tract allows the escape of bacteria which are all very well in their place-i.e., the cavity of the intestine-but which are apt to set up trouble when they make their way into other tissues. This is, however, but a subsidiary matter; the real injury caused by the Coccidium is the destruction of the lining membrane of the alimentary canal.

Coccidiosis may be spread from moor to moor by the agency of flies. The maggots of certain flies readily eat the cysts, and it has been shown both experimentally and on the moor that the cysts pass through the bodies of both maggot and fly undigested and unharmed.

Several other one-celled microscopic organisms, or protozoa, besides Eimeria (coccidium) avium, 
as is mentioned above, have been found in the intestines of grouse and also in their blood, but in no case, so far, has any of these parasites been shown to have a markedly dangerous effect on the bird harbouring it. Some of these parasites, in fact, occur in perfectly healthy grouse, and apparently are almost innocuous.

\section{STRONGYLOSIS}

The second disease which the Inquiry found responsible for grouse epizootics observed between I905 and I9ro is one to which Cobbold drew attention in I873, though he attempted little in the way of pathological investigation. According to him it is caused by the presence of a round-worm now known as Trichostrongylus pergracilis, in the cæca. We may call the disease "Strongylosis of the grouse." The worms are minute, transparent, very slender, a little less than half an inch in length, and they may exist in enormous numbers, I0,000 occurring in the two cæca of one bird. They are about equally divided between the two blind-guts. We may recall the fact that in the grouse the cæca are of unusual size, and that the digested food is absorbed in these regions of the alimentary canal alone. 
The worms seem to be most numerous at the proximal end of the cæca, and when they exist in large numbers, the contents of these most important diverticula of the alimentary canal become hard and very adherent to the mucous membrane, forming whitish patches when seen from the outside. After washing away the flocculent matter, which can only be effected with time, the mucosa frequently appears reddened. There was no reason to believe this inflammatory state is due to post mortem changes. The ridges which run along the walls of the cæca become thickened, the villi, as a rule, greatly hypertrophied (in other cases atrophied), and both villi and ridges were embedded in the abovementioned cementing material, and seem to be composed of a mixture of mucous and granular débris. Numerous Strongyles were seen adhering to the mucous membrane, and seem in places frequently to penetrate the villi. In some of the most serious cases the ridges were found to resemble masses of coral with cave-like depressions between the individual villi which frequently ceased to be distinguishable; from these depressions one or more Strongyli protruded. In section the epithelium was seen to be hyper- 
2 I4 STUDIES IN INSECT LIFE, ETC.

trophied. The muscular wall suffered from an infiltration of fibrous tissue. The fat which normally lies at the bases of the ridges in a healthy grouse had disappeared, and the bloodvessels showed thickenings of their walls. The connective-tissue base of the ridges is greatly increased, and the vessels and the villi were dilated and probably increased in number. In most places the connective tissue contained a large number of cells probably inflammatory in origin, and in some cases fibroid change was taking place. The epithelium was proliferated and thrown into folds. The lymphoid follicles were indistinguishable.

The general condition of a grouse suffering from Strongylosis shows evidence of a chronic inflammation of the alimentary canal leading to fibrosis. The Trichostrongylus in some cases penetrates to the deepest portions of the crypt. The epithelium lining these depressions when the round-worm is adjacent to the walls of the intestine has greatly altered, and there is a marked increase in the fibrous tissue at its base.

In fact we have, as Dr. Cobbett and Dr. Graham Smith, who have so ably worked out the pathology of Strongylosis, and whose results have 
appeared in the Journal of Hygiene, say, "a chronic inflammation leading to fibrosis." This portion of the alimentary canal is, in Sydney Smith's words, both "vext" and "agitated."

It thus appears that the presence of these Strongyli lead to a chronic inflammation of the cæca and to fibrosis. The normal functions of these very important organs, the cæca, are interfered with and the tissues lining them are destroyed. The bird wastes away and ultimately dies. But there is another factor in the case. When the degree of infection surpasses $I, 000$ Strongyli in each cæcum, there is no doubt a larger increase in the Bacillus coli in the liver and in the lungs and other organs. These bacilli do no harm whilst free in the alimentary canal, but when they pass the mucosa and reach the other tissues of the body they undoubtedly serve to set up various disorders.

But the presence of these worms, and also, I believe, to a minor extent the presence of the transparent tape-worm in the duodenum, has a further and indirect ill-effect on the grouse. When hand-reared birds which were free from $T$. pergracilis were investigated, practically no bacilli were found in the liver or other tissues 
2I6 STUDIES IN INSECT LIFE, ETC.

of the grouse. When the birds harboured from IOO-I,000 round-worms, bacilli occurred in the tissues of about 50 per cent. of the birds-bacilli let out from the cavity of the intestine "by a worm's pin-prick," to quote Browning's " Lovers' Quarrel." When over I,000 or more worms were present, the bacilli, with one exception were found in the liver and in other organs of the body in Ioo per cent. of the birds investigated. The exact relation of these bacilli to the sickness of the bird is still a matter of inquiry. It seems as if they are soon absorbed, and that no specific disease is traceable to them, but if they exist in numbers their products must exert a harmful influence.

The existence of disease caused by the passage of these bacilli through the walls of the alimentary canal through lesions caused by tape-worms is less well established than through the disorganisation of the lining membrane of the cæca caused by $T$. pergracilis. On the other hand, one must not overlook the fact that Hymenolepis is especially numerous in the spring and autumn months, during which the greatest mortality takes place, and is absent during the winter when the birds are comparatively healthy. 
It is seen that the small number of colonies of Bacillus coli, which can be cultivated from the tissues of a diseased grouse, points to the fact that these bacteria do not multiply to any extent in the tissues. Hence it would seem that no specific disease is caused by the infection of these bacteria. The toxic products of the bacilli, however, may be harmful, and should the bacilli exist in great numbers, there is little doubt that toxins would be produced which would have a very deleterious effect on the health of the bird.

But let us leave the bacteria and get back to the round-worms. How do they get into the grouse? Between 95 and roo per cent. of birds on different moors contain these worms. There may be as many as 10,000 in round numbers in one grouse, about equally divided between the two cæca. Each female worm lays hundreds of eggs, which are constantly passing out of the bird's body and lie scattered all over Scotland. These eggs give rise to larvæ in about two days, the larvæ surround themselves about the eighth day with a capsule or cyst, and undergo "a rest cure." After a period of quiescence they quickly change into a second and active larval form, 
2I8 STUDIES IN INSECT LIFE, ETC.

which in wet weather-a not unusual atmospheric condition in Northern Britain-writhe and wriggle and creep and crawl until they attain the stem and the leaves and the flowers of the heather. Here these larvæ wait patiently until a grouse consumes them with the heather tips, and then, once inside the alimentary canal, they become adult, make their way to the cæca, and in four days ripe eggs are again infesting the moors.

It is recorded that Prince Bismarck once said to Lady Randolph Churchill, "Have you ever sat on the grass and examined it closely? There is enough life in one square yard to appal you."

It has always seemed to me a strange thing for the Prince to have said. To begin with, throughout his long life he had shown but an imperfect sympathy with the lower Invertebrata, and then, again, he was a man not easily appalled : but the saying is perfectly true. It is difficult for the layman to grasp what is going on in and on the soil and on the plants which it supports. Suppose we could by means of a gigantic lens magnify a square yard of a grouse moor one hundred times. The heather plants would be as tall as lofty elms, their flowers as big as cab- 
bages, the grouse would be about six or seven times the size of "Chantecler" at the Porte St. Martin.

Creeping and wriggling up the stem and over the leaves and gradually yet surely making their way towards the flowers would be seen hundreds and thousands of silvery-white worms about the size of young earthworms. Lying on the leaves and on the plant generally would be seen thousands of spherical bodies the size of grains of wheat, the cysts of the Coccidium, and on the ground and on the plants as large as split-peas would be seen the tape-worm eggs patiently awaiting the advent of their second host. It is perhaps a picture which will not appeal to all, but yet it represents what unseen and unsuspected is always going on on a grouse moor.

Two other points remain, the seasonal character of the disease, and whether any means can be suggested to check either Coccidiosis or Strongylosis, or both.

"Grouse disease" is always said to be at its worst in the spring months, to decline during the summer, and to recrudesce in a milder form in the autumn. Coccidiosis undoubtedly is a spring disease; it attacks the chicks, and if they 
survive the first six or seven weeks of their life they usually live to grow up. This disease certainly abates during the summer, but it does not recrudesce during the autumn. Strongylosis also occurs most virulently in the spring, when the birds are exhausted by a winter of semi-starvation and the female especially by the demands made on her by egg-laying; it is also prevalent in autumn, but the worst cases have by this time presumably been killed off, and those not so heavily afflicted are still struggling to survive. It is not as a rule reported during June and July, but very few know what happens on the moor during these months. The grouse are almost unseen, their state of health unknown. This again is a matter for further inquiry, but at present the view that " disease" dies down during the summer has little but negative evidence to support it. It probably lingers on, gradually lessening in intensity until the near approach of August I2th again attracts the attention of the moor owner and the sportsman to his birds.

With regard to the prevention of the disease, a hopeful view can be taken. Intelligent management has already diminished and in certain cases almost, if not quite, eliminated the danger 
of disease, and this without resort to outside aid or scientific advice. There is reason to hope, with a clearly defined objective and a more general realisation on the part of moor owners not only of the immediate cause of grouse disease, but also of the contributory conditions leading thereto, that the best methods which obtain at present in moor management will be more widely adopted, and that the suggestions of new lines of experiment which has been put forward in the final Report will be followed up.

As to the stay of the disease when fully established in the bird no practical remedial measures can at present be suggested. The apothecary is to the sick bird of no more importance than Seneca. Nothing can be done "pour soulager les entrailles" of the patient. 
Chapter IX

\section{ZOOLOGY IN THE TIME OF SHAKESPEARE}

Through the Middle Ages natural science was a study of the written word of ancient writers, whose authority went unquestioned. Processes of observation or experiment were barely known. To this medieval tradition the age of Shakespeare, in its attitude to scientific study, was to a large extent loyal. Authority was still final and definite. What Galen and Hippocrates, Aristotle and Pliny had written was subject-matter for dialectic, for discussion, for argument, but not for direct investigation. In the same way the new light derived from the Arabs, which spread through the learned world at the latter end of the twelfth and at the beginning of the thirteenth centuries, was treated as a matter for dialectics by those who set the written word before actual observation or experiment in Nature.

Let us consider the books in English at the 
disposal of an average man in the latter half of the sixteenth century. Through medieval times had drifted a certain "corpus" of moralised natural history known as the "Physiologus," which was in essence a Bestiarium. It took various forms, and was read throughout Europe and the Near East. This "Physiologus" was primarily religious in its aim, but dealt not only with the animals mentioned in the Bible but with other and often mythical monsters. Scientifically the zoology of the "Physiologus" was of the poorest : in fact, the study of zoology was at its worst during the Middle Ages; it had fallen far lower than in classical days. The "Physiologus " had its origin in Alexandria in early Christian times, and was translated into many tongues, including Coptic. It was sometimes fathered upon Ambrose, but is older than his day.

During the eleventh century a certain "Episcopus incertus," one Theobaldus, made a metrical version of the descriptions of twelve of the animals dealt with in this little volume. This was published under the name "Physiologus Theobaldi Episcopi de naturis duodecim animalium," the earliest printed edition being that issued at Delft in I487. Numerous editions were published in many 
countries for the following century or two, but the contents of the volume were in a state of flux, additions and omissions appearing in many of the issues.

Another most voluminous and remarkable work was the "Speculum naturale" of that marvellous compiler Vincent of Beauvais. It was an encyclopædia of natural objects, and a mine of information which has since been frequently quarried. Vincent was a learned Dominican born in France about IIgo. We know almost nothing of him except that he died about I264. He is presumed to have lived in the Dominican House at Beauvais, but there is no evidence in support of the story that he was Bishop of that diocese. The "Speculum naturale," like his other monumental tomes, shows no originality and no firsthand knowledge of the animals he describes, but his industry was colossal and his application untiring. As an example of his erudition it may be mentioned that in the "Speculum naturale" he quotes the names of no fewer than three hundred and fifty different authors, Latin, Greek, and Arab. The work was magnificently produced in 1473 by Jean Mentelin of Strassburg. But the chief book on natural history in the 
Middle Ages was an encyclopædia entitled " Liber de Proprietatibus Rerum," compiled by the English Franciscan, Bartholomew, often called Bartholomaeus Anglicus, who probably wrote sometime about I250, certainly before 1267 , and in all probability before 1260. Both before and after the invention of printing this work had a wide circulation. The "Liber" was translated into French by the order of Charles V., into Spanish in I372, then into Dutch, and in 1397 into English. It was also the first book printed on paper which had been made in England. This book is believed to have been the source of much of Shakespeare's knowledge of natural history. In $5_{582}$ the Rev. Stephen Bateman, D.D., domestic chaplain to Bishop Parker, re-issued the -English translation made by John of Trevisa which had been printed in I494 by Wynkyn de Worde at Westminster. The book was entitled:

"Batman uppon Bartholome, His Booke De Proprietatibus Rerum, Newly corrected, enlarged, and amended, with such Additions as are requisite, unto every severall Booke. Taken foorth of the most approved Authors, the like heretofore not translated in English. Profitable for all Estates, 


\section{STUDIES IN INSECT LIFE, ETC.}

as well for the benefite of the Mind as the Bodie." Lond. I582, fol. Dedicated to Lord Hunsdon.

Incomplete translations of Pliny from the French had appeared in ${ }^{565}$, and again in 1587 . In I6oI Philemon Holland, M.D. (I552-I637), in later life headmaster of Coventry Grammar School- "the translator generall in his age," as Fuller calls him-published a more complete version of Pliny under the title "The History of the World, commonly called the Natural Historie of Caius Plinius Secundus." This treats of all phases of nature, and contains a record of all natural knowledge up to the time of the younger Pliny. Nor must it be forgotten that the writings of Pliny and the "Georgics" of Virgil were in constant use in the schools.

In the middle of the thirteenth century Roger Bacon had pointed out that "There are two ways of knowing, viz. by means of argument and by experiment," but for three centuries onward it was " argument" which held the field. Not that the sixteenth century failed to produce enlightened men who were to preach a new doctrine. In his educational work "De Tradendis Disciplinis" (I523) Vives advocates " nature 
study" and even uses the expression. He tells us "That although the writings of the old Greeks and Romans are the opinions of learned men, yet not even all these opinions and judgments are to be accepted." Vives recommends that the pupil should first be shown what he can most readily perceive by the senses :

"So will he observe the nature of things in the heavens, in clouds and in sunshine, in the plains, on the mountains, in the woods. Hence he will seek out and get to know many things from those who inhabit those spots. Let him have recourse, for instance, to gardeners, husbandmen, shepherds, and hunters, for this is what Pliny and other great authors undoubtedly did; for any one man cannot possibly make all observations without help in such a multitude and variety of directions. But whether he observes anything himself, or hears anyone relating his experience, not only let him keep eyes and ears intent, but his whole mind also, for great and exact concentration is necessary in observing every part of nature."

We can but judge the state of zoology in Queen Elizabeth's time by the books and writings that 
have come down to us, and if we inquire what books and writings were available, they will be found to fall under the three headings, Medicine, Fieldcraft, and Heraldry. From these subjects the paths of progress in that science were advancing and converging.

The year that saw the birth of Shakespeare witnessed in the remote island of Zante the death of Vesalius, who, as a medical student at a hospital in Venice, had rubbed shoulders with a young soldier, Ignatius Loyola, who six years later founded the Order of the Jesuits. Vesalius, who was born at Brussels on the last day of the year I5I4, was the first biologist to abandon authority. Dispensing with the aid of unskilled barbers, he dissected the human body with his own hands. Like Harvey, whose discovery of the circulation of the blood dates but three years after Shakespeare's death, he

"Sought for Truth in Truth's own Book, The creatures, which by God Himself was writ, And wisely thought 'twas fit,

Not to read Comments only upon it,

But on the original itself to look."

At the beginning of his scientific career, like his master Sylvius, Professor at the College of 
ZOOLOGY IN TIME OF SHAKESPEARE 229

France, Vesalius trusted the written word of Galen more than he trusted his own eyesight, but in the end his sight and his reason conquered, and at last he taught only what he himself could see and make his students see.

Vesalius was the founder of modern anatomy, physiology, and, I think we may say, also of modern zoology, for the methods of these sciences are one. His great work on "The Structure of the Human Body" appeared at Basle in I543, and was beginning to have influence in England, but only amongst the learned, well before Shakespeare was born.

His English pupils, amongst whom was John Caius the third, founder of Gonville and Caius College, helped to spread his methods and principles in this country. Amongst the many pupils of John Caius we may mention Thomas Moffett. Few men in those days lived much over fifty years, and Moffett, born in 1553 , died in I604. He joined Trinity College in 1569 , but migrated to Caius in I572, where he was nearly poisoned by eating mussels. After taking his M.A. degree, he, as was the habit of the time, studied abroad and received in 1578 the degree of M.D. at Basle, where he was a pupil of Felix Plater and of Zwinger. 
The following year he travelled in Spain and Italy, and in these countries he made an elaborate study of the silk-worm, which doubtless led him to the study of insects in general. He not only wrote a poem on the silkworm, but collected notes on the natural history of the Insecta. These were published thirty years after his death under the title " Insectorum sive Minimorum Animalium Theatrum-ad vivum expressis Iconibus super quingentis illustratum." An English translation entitled the "Theater of Insects" was published as an appendix to Topsell's " History of FourFooted Beasts and Serpents" in I658.

Moffett was a many-sided man of science, a practising physician, a traveller who at Copenhagen had known Tycho Brahe, a courtier who took part in both diplomatic and military service abroad, a poet and writer of epitaphs and epigrams, a keen critic of diet, and for some time a member of the House of Commons.

A friend of Moffett's was Thomas Penny, who entered Trinity College in $\mathrm{I}_{550} \mathrm{O}$, and later became not only a Prebendary of St. Paul's, but a sound botanist and entomologist. Like so many men of the time, Penny travelled extensively on the Continent. He visited Majorca, lived in the 
south of France, and worked in Switzerland with Gesner. He is believed to have been with Gesner when he died, and he certainly helped to arrange the natural history specimens which the great master left. It was probably through Penny that Gesner's drawings of butterflies passed into the care of Moffett, whose "Theatrum" states on its title-page that it was begun by Edward Wotton, Conrad Gesner, and Thomas Penny.

The contents of books revealing new knowledge diffused themselves among the ordinary public in Shakespeare's time far more slowly than at present. On the other hand, studies were then far less specialised than they now are. For example, we find Milton placing medicine in the curriculum of a liberal education, and John Evelyn studying "Physics" at Padua. Lord Herbert of Cherbury insists on the necessity of a gentleman being able to diagnose and treat disorders, and thinks he should have a knowledge of anatomy. "Whosoever considers anatomy, I believe, will never be an atheist," was one of his recorded sayings. Dealing with the matter broadly, I think we may endorse the statement of $\mathrm{Mr}$. Foster Watson: "It is noteworthy, that in both botany and zoology the main advances were made 
by professed physicians," and we must not forget that Elizabethan botany was more advanced than Elizabethan zoology.

Something, however, was learned from husbandry and field sports. "Let the student," says Vives, "have recourse, for instance, to gardeners, husbandmen, shepherds, and hunters," and in "De rebus rusticis" he says, "Let the boy read Cato, Varro, Columella, Palladius." "Vitruvius is important for naming with the greatest purity and accuracy most objects of the country." Virgil with his marvellous account of apiculture and other agricultural pursuits was much read during this period.

The gentlefolk also in Queen Elizabeth's time were much interested in the study of heraldry, for indeed it was a very gentlemanly pursuit. Gerard Legh's "Accedens of Armory" (I562), and John Guillim's "A Display of Heraldry" (I6I0), included descriptions of creatures which enabled the owners of animal crests and supporters to appreciate the nature of what they bore and of what supported them.

In Shakespeare's time, although a knowledge of physiology and human anatomy was beginning to emerge, such objects as comparative anatomy, 
ZOOLOGY IN TIME OF SHAKESPEARE 233 morphology, and embryology were non-existent. In dealing with the animal kingdom, the first need of the earlier writers on zoology was to make some sort of classification, and even in the later Tudor times such attempts at classification rested almost wholly on external characteristics. These arid catalogues of animals were usually lightened by the addition of notes on their habits-often of the quaintest and most bizarre descriptionand by short accounts of such medical properties as the fantastic pharmacy of the sixteenth century attributed to various beasts.

William Turner in 544 published his " Avium Praecipuarum quarum apud Plinium et Aristotelem mentio est, brevis et succincta historia," dedicated to Edward Prince of Wales afterwards Edward VI. Turner had been educated at Pembroke College, Cambridge, where he knew Latimer and learned Greek from Ridley. He travelled much abroad and became an M.D. of Ferrara and subsequently of Oxford. Later in life he was ordained, and in I550 he was appointed Dean of Wells, a post he was compelled to quit on the accession of Queen Mary. His business in life was theological controversy and he wrote many polemical works, but his pleasure was in 
234 STUDIES IN INSECT LIFE, ETC.

natural history. He was a learned botanist, and he published a "Libellus de re herbaria" in I538. He also contributed a letter on British. fishes to his friend Conrad Gesner, with whom he had worked at Zurich and with whom he constantly corresponded. As an example of the zoology available in Shakespeare's time, we may quote Turner's description of the grouse :

\section{"Of the Lagopus," from Pliny.}

“The Lagopus is in flavour excellent, its feet shaggy as in a hare have given it this name. Otherwise it is white, in size as the Columbi; it is not eaten except in the land of which it is a native, since it is not tameable while living, and when killed its flesh soon putrefies. There is another bird of the same name, differing but in size from the Coturnices, most excellent for food with yellow saffron sauce. Of this Martial makes mention in the following verse :

"If my Flaccus delights in the eared Lagopodes."

Although this may seem to indicate that Turner was a mere translator and compiler, this is not the case. As Mr. Evans says :

" while attempting to determine the principal 
ZOOLOGY IN TIME OF SHAKESPEARE 235

kinds of birds named by Aristotle and Pliny, he has added notes from his own experience on some species which had come under his observation, and in so doing he has produced the first book on Birds which treats them in anything like a modern scientific spirit ... nor is it too much to say that almost every page bears witness to a personal knowledge of the subject, which would be distinctly creditable even to a modern ornithologist."

A contemporary of Turner's, Edward Wotton (I492-I555), born at Oxford and elected a Fellow of Magdalen, travelled for several years in Italy. He took his M.D. at Padua, and later held high office in the College of Physicians, and has been described as "the first English Physician who made a systematic study of natural history." His book "De Differentiis Animalium," published two years before Turner's "Historia" and dedicated to the same patron, acquired a European reputation. The copy of this book, a fine folio, in the British Museum is said to be "probably unsurpassed in typographical excellence by any contemporary work." "De Differentiis Animalium " was deservedly praised by contemporary 
writers for its learning and for the elegance of its language.

Dr. Caius (I5IO-I573) in his terse style wrote "De Canibus Britannicis libellus," I570, and this was "drawne into Englishe" under the name " Of Englishe Dogges " by Abraham Fleming in 1576 and published in London. Caius wrote his little book as a contribution to Conrad Gesner's "History of Animals," but owing to Gesner's death it was not incorporated in that work.

From the sixth year of Henry the Eighth until the death of Queen Elizabeth all the learned men of Europe who were interested in nature turned to Gesner, the incomparable naturalist of Zurich (I5I6-I565). Born of humble parents, he learned and taught and wrote with untiring perseverance and energy until he became the most erudite and the best known man of learning of his day. Quite apart from his acquirements in what we now regard as science, he was a most remarkable linguist and bibliographer. In $\mathrm{I}_{537}$ he held the Professorship of Greek at Lausanne, and in his "Mithridates" he made one of the earlier attempts at comparative philology, considering all language from the Ethiopic to the Gypsy. In 
ZOOLOGY IN TIME OF SHAKESPEARE 237

this book he printed the. "Pater Noster" in no fewer than twenty-three tongues.

Amongst many other works of great importance his stupendous "Historia Animalium" is perhaps the most remarkable. In the decade beginning I540 Gesner began to collect material for his great Natural History. He read between two and three hundred volumes, he travelled extensively in Europe, interviewing and learning from agriculturists, shepherds and hunters as well as "Gelehrten." Everywhere he was helped by the eager efforts of his fellow workers in natural history.

Just before Shakespeare's death in the year I607, Edward Topsell, a member of Christ's College and in the matter of livings somewhat of a pluralist, published under the title "The Historie of Foure-Footed beastes " an abstract of Gesner, and in the next year followed it up with " The Historie of Serpents," both illustrated with charmingly quaint, if inaccurate, woodcuts. Topsell had, what the modern zoologist must have (but the possession in his time was less common), a sound knowledge of German, and to this knowledge his books owe so much. These books give us a fair idea of what the 
educated in those days knew of zoology in all its aspects, and that these aspects covered a far wider area than, with the present expansion of knowledge, we can now contemplate under this single science, is shown by the title-page to Topsell's magnificent quarto volume :

"The History of Foure-Footed Beastes. Describing the true and lively figure of every Beast, with a discourse of their severall Names, Conditions, Kindes, Vertues (both naturall and medicinall), Countries of their breed, their love and hate to Mankinde, and the -wonderful worke of God in their Creation, Preservation, and Destruction. Necessary for all Divines and Students, because the story of every Beast is amplified with Narrations out of Scriptures, Fathers, Phylosophers, Physitians, and Poets: wherein are declared divers Hyerogliphicks, Emblems, Epigrams, and other good Histories, collected out of all the Volumes of Conradus Gesner, and all other Writers to this present day. By Edward Topsell. London, Printed by William Jaggard, I607."

If now we leave the general consideration of the knowledge of the science of zoology accessible in Shakespeare's time, and turn to the acquaint- 
ance of the subject he displays in his writings, we shall find that he had just that knowledge which a quick, observant, intelligent man of the world who has not paid special attention to the matter would pick up in the course of his upbringing and of his career. We have the feeling that he is describing what he saw, and that he is copying nature-as far as he knew it-without attempted emendation or improvement. His outlook on the world is always steady and sane.

A large number of books and a very large number of articles have been written about the "Birds of Shakespeare," "Reptiles mentioned in Shakespeare's Plays," "The Natural History of Shakespeare" etc., etc. On an inspection of these writings it seems that their authors have a common desire to exalt our greatest dramatist at the expense of what must have been the truth. Novelists and writers of plays constantly put into the mouths of their creations remarks which in their judgment the speaker would utter under certain circumstances and at certain times. The fact that Hero refers to the lapwing and Bottom to the ousel is no proof that Shakespeare was a trained ornithologist. I should profoundly mistrust George Eliot's diagnosis of a species of land 
mollusc, yet $\mathrm{Mr}$. Brooks strongly urged $\mathrm{Mr}$. Casaubon to unbend and take up the study of conchology, although he had himself gone into science a great deal and "saw it would not do." In the "Doctor's Dilemma" the physicians talk fluently and well about bacteria, but few of us would trust Mr. Bernard Shaw to make a "pure culture." In fact we can all talk a good deal about a subject, and even more readily let a puppet talk for us, without really knowing much about it. Still there is no doubt that, as far as a keen sportsman could study, under the conditions of the time he lived in, Shakespeare had studied nature at first hand. But it is as a sportsman, not as a zoologist or even as a naturalist, that he must be judged. Professor Raleigh tells us that " it has been truly said that he was curiously unobservant of animated nature." I doubt that "truly." He certainly adopted many of the traditions of the past without inquiry. Professional writers on zoology in Elizabeth's time did the same. That he misstated facts about the nightingale and the cuckoo is true, but even in this year of our Lord we have still much to learn and much to discard in our knowledge of the latter bird. If the "glittering poetry" of the 


\section{ZOOLOGY IN TIME OF SHAKESPEARE 24I}

famous passage on bees in "Henry $\mathrm{V}$." is not an accurate record of the economy of a hive, we may infer that, unlike Virgil, unlike Maeterlinck, and unlike Mr. Rudyard Kipling, Shakespeare never kept a bee. After all it is the Archbishop of Canterbury who is speaking, and I, who have read the lives of many Archbishops of Canterbury, cannot recall a really expert apiculturist amongst them all. In his allusions to field sports, as in so much else, he strikes one as amazingly competent. He made, when we judge him by the standard of his times, comparatively few mistakes; his metaphors drawn from the animal world were on the whole appropriate. In this as in all other aspects of his genius he had "das Gefühl."

Shakespeare certainly had a first-hand knowledge of falconry. In Elizabeth's time this sport was " much esteemed and exercised." People of all classes eagerly took part in it. To quote Mr. Harting :

"The rank of the owner was indicated by the species of bird which he carried. To a king belonged the gerfalcon; to a prince, the falcon gentle; to an earl, the peregrine; to a lady, 
the merlin; to a young squire, the hobby; while a yeoman carried a goshawk; a priest, a sparrowhawk ; and a knave, or servant, a kestrel."

The sport was, however, expensive, for it took much time and devotion to train the birds. Falconry in those times, as the flying machine is in ours, was in the air, and just as one now hears our undergraduates discussing carburetters, air-locks, sparking-plugs, and various vintages of petrol, so in the times of Queen Elizabeth the keen young men of Shakespeare's Plays discussed the various kinds of hawks and their habits.

The towering of a falcon is referred to in "Macbeth" (II. iv. I2) in a sense that has since become unusual :

"On Tuesday last,

A falcon tow'ring in her pride of place

Was by a mousing owl hawk'd at and kill'd."

At the present day the expression "towering" is restricted to a bird that has been hit but which flies on for a space as though unhurt, and then suddenly and rapidly rises almost vertically before dropping dead. The probable explanation is that hemorrhage has filled the lungs or bronchial tubes with blood, and the upward rise is a 
despairing effort to get breath. In Harting's "Ornithology of Shakespeare" there is an interesting chapter on Hawking, or as Shakespeare so often called it "Birding," with an account of all the apparatus of falconry. Here we may perhaps confine ourselves to explaining a few technical terms. "Pitch"-(cf. "How high a pitch his resolution soars ")-indicates the height to which a hawk rises before he' begins his swoop. The "stanniel" to which Sir Toby Belch refers when he exclaims "And with what wing the stanniel checks at it " ("Twelfth Night," II. 5), is the "standgate" or kestrel hawk, which hovers over a mouse much as Malvolio checks at Maria's letter dropped in his path. Another case where, according to Harting, Shakespeare refers to a particular species of hawk is when Mrs. Ford addresses Falstaff's page: "How now, my eyas musket!" Musket was the name used by falconers for the male sparrow-hawk; eyas indicates a fledgling. "But there is, sir, an aiery of children, little eyases, that cry out on the top of the question, and are most tyrannically clapped for't: these are now the fashion." Writing in the days of "Peter Pan" and the "Blue Bird" one feels that history does repeat itself. The 
244 STUDIES IN INSECT LIFE, ETC.

"tercel" is thought to have been the shortwinged male goshawk as opposed to the "tercel (or tassel) gentle," the male of the larger-winged peregrine :

" $\mathrm{O}$, for a falconer's voice

To lure this tassel-gentle back again."

("Romeo and Juliet," II. ii. I58.)

The lure consisted of a leather thong appended to a piece of metal or wood to which were attached a couple of birds' wings and a scrap of raw meat. This was either whirled round his head by the falconer or thrown some distance; at the same time the falconer shouted to attract the bird. Each falconer had his own call, which the hawks were taught to recognise. In the case of hawks that flew very high, a live pigeon restrained by a string was sometimes used as a lure.

The game or "quarry" (cf. "This quarry cries on havoc," "Hamlet," V. 2) differed with different hawks. The gerfalcon and peregrine were flown at water-fowl, pigeons, rooks, and magpies; the goshawk at partridges and hares; small forms, such as the merlin and hobby hawk, at larks and blackbirds.

In the passage : 
"If I do prove her haggard, Though that her jesses were my dear heart-strings I'ld whistle her off, and let her down the wind To prey at fortune("Othello," III. iii. 260.)

" haggard" means a grown-up bird caught wild and untamed. It should be here mentioned that hawkers fly their birds against the wind; if flown "down wind" they are apt to disappear altogether.

The " mew " (ct. "To-night she's mewed up," "Romeo and Juliet," III. 4) was the "place whether it be abroad or in the house, where you set down your hawk during the time she raiseth or reproduceth her feathers." The word is said to be derived from the French mou, or moult. At such a time great care must be taken of the birds, who under quite unnatural conditions are apt to pine and die. In Henry VIIII.'s time the mews at Charing Cross, which, according to Stowe, had sheltered the royal hawks since Richard II.'s reign, were converted into stables. Horses replaced hawks, but the name mews persisted. "Mewses must exist," as Mrs. Billickin tells us in "Edwin Drood."

Another technical expression connected with hawking is to "imp": 
"If then we shall shake off our slavish yoke, Imp out our drooping country's broken wing."

("Richard II.," II. i. 29I.)

This term indicates the replacement of a damaged feather, where the shaft remains, by a portion of a whole feather of another bird. The falconers knew each wing and tail feather and collected examples of each for use as required. The old damaged feather was pruned into what we may call a stump, and the substitute feather obliquely cut so as to fit into it. Sir John Sebright, quoted by Harting, tells us in his "Observations on Hawking" that the falconer for the purpose of uniting the old stump with the new feather "is provided with an iron needle... and after wetting the needle with salt and water "-notice the anticipation of our modern antiseptic methods - "thrusts it into the centre of the pith of each part, as truly straight, and as nearly to the same length in each as may be. When this operation has been skilfully performed the junction is so neat that an inexperienced eye would hardly discern the point of union."

A cruel habit of sewing the upper and lower eyelid together with a thread to accustom the hawk to the "hood" was termed "seeling." 
"The wise gods seel our eyes" ("Antony and Cleopatra," III. xiii. II2). Note also "To seel her father's eyes up close as oak" ("Othello," III. iii. 2IO), where Mr. Harting suggests the reasonable emendation "close as hawks."

Altogether Shakespeare mentions between seventy and eighty different birds, and as Pope reminds us "with competent . . knowledge." His references to coursing are less numerous. Coursing is one of the. oldest sports of which we have detailed record. Arrian, in A.D. 150, wrote a treatise upon coursing the hare, and with the true feeling of the sportsman says the coursers " do not take their dogs out for the sake of catching a hare, but for the contest or sport of coursing, and they are glad if the hare escapes." When matches were first made between the dogs is unknown, but during the reign of Elizabeth, and by her special command, "laws of the Leash or Coursing" were drawn up by Thomas Duke of Norfolk. One of the few references made by Shakespeare to this sport is in the famous speech to the English soldiers at the siege of Harfleur:

"I see you stand like greyhounds in the slips, Straining upon the start."

(“Henry V.," III. i. 3I.) 
248 STUDIES IN INSECT LIFE, ETC.

Deer shooting with bow and arrow or crossbow was also a favourite form of sport, and to this Shakespeare refers more frequently. It was a sport which appealed especially to ladies, for whom stands, or "standings," were erected, and the deer driven past by keepers or hounds. The deer were also followed on horseback. Mr. Harting, quoting a letter from Rowland White to Sir Robert Sidney, dated I2th September, I600, tells us that Queen Elizabeth " is well and excellently disposed to hunting, for every second day she is on horseback and continues the sport long." In I600 the Queen was in her sixty-seventh year.

In the opening scenes of Act IV. of "Love's Labour's Lost " Shakespeare refers to the "standings" for ladies, and again in Act III. of " 3 Henry VI.," and also in "Cymbeline" and "The Merry Wives of Windsor." Above all we must not forget "What shall he have who killed the deer ?" in "As You Like It." The fine description of the "roan Barbary" in the last scene but one of "Richard II." shows Shakespeare's love of a horse.

The mythical animals mentioned in Shakespeare's plays are the unicorn, the phœnix, the cockatrice or basilisk, the griffin, and the dragon. 
Pliny's unicorn, or monoceras, was an animal all compact of the stag, the elephant, the boar and the horse. It had a deep "lowing voice," and it is not surprising to learn that it "cannot be taken alive." Its single horn, two cubits in length, projected from the centre of its forehead. The unicorn was introduced into the royal arms when James VI. of Scotland became James I. of Great Britain and Ireland; but long before this time the traditional fight between the lion and the unicorn was mentioned by Spenser in his "Faerie Queene" :

"Like as the lyon, whose imperial poure

A proud rebellious unicorn defyes."

Shakespeare refers both to the unicorn and to the phœnix with an evident note of scepticism in "The Tempest," III. iii. :

\section{"Now I will believe}

That there are unicorns; that in Arabia There is one tree, the phœnix' throne; one phœnix At this hour reigning there."

Pliny also placed the phœnix in Arabia-still the most unexplored country in the world-but "was not sure that its existence is not a fable." According to the same authority the phœnix 
lives 540 years, and there is but one on the earth at a time. This rarity is dwelt on by Rosalind ("As You Like It," IV. iii. I7), who anticipates Charles Lamb's "If they were young phœnixes, indeed, that were born one in a year!" Its habit of expiring in what Mr. Crummles called a "blaze of fireworks," and from its bones and marrow engendering again " at first a sort of small worm, which in time changes into a little bird," were all well known to Shakespeare's characters.

Among other mythical animals to which Shakespeare frequently refers is the basilisk, or cockatrice, which is figured by Aldrovandus as a scaly, long-tailed animal with four pairs of legs, carrying a crown upon its beaked head. Topsell tells us :

"This Beast is called by the Græcian Baziliscos and by the Latine Regulus, because he seemeth to be the King of Serpents, not for his magnitude or greatnesse: For there are many Serpents bigger than he, as there be many foure-footed Beastes bigger than the Lyon, but, because of his stately pace, and magnanimious mind: for hee creepeth not on the earth like other Serpents, but goeth halfe upright, for which occasion all other Serpentes avoyde his sight. And it seemeth 
nature hath ordayned him for that purpose; for, besides the strength of his poyson, which is uncurable, he hath a certain combe or Corronet uppon his head, as shall be shewed in due place."

Pliny records that the basilisk destroys all shrubs not only by contact, but even those it breathes upon; it burns up grass and breaks the stones, so tremendous is its noxious influence. The origin of this baleful creature was believed to be from a " Cockes egge " laid when the " Cocke groweth old ... about the beginning of the Dogge-dayes.... and afterwards sat upon by a snake or toad." Another school, however, held the view "that the Cocke doth sit on that egge himselfe."

The fatal effect of the eyes of the basilisk, " redde, or somewhat inclyning to blacknesse," is referred to many times in Shakespeare's plays. We give but two instances :

"I'll slay more gazers than the basilisk."

(3 "Henry VI.," III. ii. I87.)

"Would they were basilisks, to strike thee dead."

("Richard III.," I. ii. I5I.)

The only effective way of dealing with the basilisk was to "exhibit," as the doctors used 
to say, a weasel. The effluvium of this animal destroyed the cockatrice, but the weasel also perished.

On dragons one could write a volume. There was the unwinged class, such as the dragon of Wantley, and the "laidley worme" of Lambton, and there was the winged dragon such as St. George slays on our golden sovereigns, * "more furious and wicked than the wormes," one curiously reminiscent of the fossil plesiosaurs, the other of the pterodactyls. Most of the references, and there are some ten or twelve, in the plays are to the winged variety.

The griffin, which we must carefully distinguish from the gryphon, was a gigantic animal with, as Mandeville, who knew all about it, tells us, "the body before as an Ele, and behind as a Lyon." It was "greater than eight Lyons" and could carry to its nest a horse with a man on its back or a yoke of oxen. It lived in places very inaccessible to men of medieval or Tudor times : in Bactria, according to Mandeville; "in the far northern mountains," according to Olaus Magnus; while Marco Polo locates it in Madagascar. Hotspur, who could not stand a pedant, says :

* Written before the war-notes. 
"Sometimes he angers me

With telling me of ....

A clipt-winged griffin."

$$
\text { (I "Henry IV.," III. i. I52.) }
$$

The creatures which aroused most interest in Tudor times were those who could, even in a distant manner, mimic or be referred to man. The human being was the type, the lord of creation, the standard to which other animals must in structure and function conform. Hence monkeys, and in particular the anthropoid apes, had a paramount attraction. Seals and manatees (= mermaids) owed their popularity to the same effort to refer the marine mammals to the standards of our poor humanity. As Trinculo says in "The Tempest" :

"Were I in England now, as once I was, and had but this fish painted, not a holiday fool there but would give a piece of silver ; there would this monster make a man ; any strange beast there makes a man. When they will not give a doit to relieve a lame beggar, they will lay out ten to see a dead Indian."-("The Tempest," II. ii. 29.)

Other animals of a dangerous and savage disposition such as bears and lions also provedwhen behind stout bars-stimulating to the public, who probably tormented these unhappy carnivora to the limit of their endurance. Bear-baiting was 
254 STUDIES IN INSECT LIFE, ETC.

of course common. The bears at Berne are a survival of these Tudor times, and illustrate the old-world habit of immuring bears in pits, a habitat alien to their nature and affording man but one aspect of their external bodily structure. Monstrosities, sometimes manufactured, as the mermaid is to this day fabricated in the East, by joining a monkey's head and body to a fish's tail, always excited interest and aroused the speculation of the uninformed.

Man is a collecting animal, and in the Middle Ages the monasteries and the churches were often the repositories of the various objects of nature and art amassed by the traveller and the connoisseur. The opening up of the sea route to the East, the discovery of America, and the consequent foundation of "factories" both in the East and in the West, combined with missions to " ye heathern," led to considerable accumulations of natural history objects, and to the formation of museums. But for the most part the collections remained in the house of the collector and were largely made up of archæological and ethnological specimens. Before Shakespeare's date such collections were made on the Continent by Ulisse Aldrovandi (I527-I605), "omnis fere eruditionis 
oceanus," whose collection is still preserved at Bologna; by Archduke Ferdinand II., in his castle of Ambras, near Innsbruck; by Francesco Calzolari (Calceolari) of Verona, after whose father the flower is named; by Berend Ten Brocke (Bernardus Paludanus), I550-I633, of Enkhuizen, whose Wunder-Kammer was visited in $\mathrm{I}_{592}$ by Frederick, Duke of Würtemberg-the "Duke de Jamany " of Dr. Caius ; by Felix Plater of Basle, and by many others. England, when she does not lead the way, is apt in such matters to lag a good deal behind other countries, though with time she usually overtakes and surpasses those who have initiated new ideas. In the sixteenth century we had no collections that would compare with those on the Continent. What natural history specimens the country then possessed were scattered in noblemen's libraries, in churches, and in the apothecary's shop:

"In his needy shop a tortoise hung, An alligator stuff'd, and other skins Of ill-shaped fishes."

(" Romeo and Juliet," V. i. 42.)

Shakespeare had no great museums or collections, or even experts to consult. It was not till far on in the seventeenth century that England 
256 STUDIES IN INSECT LIFE, ETC.

took her proper position as a home of great and public collections. The way was led by John Ray and by John Tradescant and his son of similar name, whose museum was acquired in I659 by Elias Ashmole, and by him presented to the University of Oxford in I682.

If we make a classification of the various animals mentioned by Shakespeare we shall find that with the exception of the coral whose skeleton alone he knew, his knowledge did not extend below the leeches and worms, the Annelida. He knew that leeches suck blood, and incorrectly, like Job, he extended this practice to the horse-leech Aulostoma, which as a matter of fact feeds on earthworms. The word worm is used in his plays in the most comprehensive way for all long, wriggly creatures, not only for Annelids but for reptiles and for dragons. "Civil dissension is a viperous worm" (I “Hen. VI.," III. i. 72). Cleopatra's asp is "the pretty worm of Nilus" ("Ant. and $\mathrm{Cl}$.," V. ii. 243). In "Measure for Measure" (III. i. I7) "the soft and tender fork of a poor worm " is in all probability the forked tongue of a snake. Most insect larvæ were also termed worms. "The worms were hallow'd that did breed the silk" ("Othello," III. iv. 73), and again 
referring, without knowing it, to the rose chafer's - larva, "Why should the worm intrude the maiden bud ?" (" Rape of Lucrece," 848).

His knowledge of molluscs was, though more accurate, in no sense wider. He knew the "cockle (Pecten) hat " of the pilgrim ("Ham.," IV. v. 25), but thought the animal "sails seas " ("Per.," IV. iv. 2) ; he mentions as articles of food "the freshbrook muscles " ("Temp.," I. ii. 463) ; he knew, as all the world since classical times had known, "this treasure of an oyster" ("Ant. and Cl.," I. v. 44). Its tardiness ("As You Like It," IV. i. 52) and its tenderness ("Ven. and Ad.," I033) alike impressed him. The "saucy cuttle" of Doll Tearsheet (2 "Hen. IV." ; II. iv. II8) does not argue an acquaintance with the Cephalopods, but may have been a term of endearment or more probably a slang term for " cutpurse."

The Crustacea are but sparingly referred to. Shrimp ("Love's Labour's Lost," V. ii. 594) is used as a paraphrase for babe. The crab, it is said, " could go backward" ("Ham.," II. ii. 206). As a matter of fact it moves sideways, though sometimes with an oblique backward bias. Caliban makes the only reference to the large subdivision 
258 STUDIES IN INSECT LIFE, ETC.

of the order, the Entomostraca, in " all be turned to Barnacles" ("Temp.," IV. 249).

Although the comprehensive word "worm" was widely used in Elizabethan days for the grubs, maggots, and caterpillars of insects, only the more obvious of the mature insects, the imagos, are mentioned by Shakespeare. The Orthoptera are represented by the cricket, "as merry as crickets," says Poins (I "Hen. IV.," II. iv. I00), and by the grasshopper. Shakespeare knew and appreciated the effect on cattle of the "breeze-fly." Beetles are referred to several times without any attempt to discriminate between the genera or even families of this enormous order. It is improbable that Shakespeare recognised that the glow-worm which he mentions frequently in some of his most charming passages is as a rule a beetle. The Lepidoptera again appeal to Shakespeare's amazing sense of beauty :

"And pluck the wings from painted butterflies, To fan the moonbeams from his sleeping eyes."

("Midsummer Night's Dream," III. i. I75.)

In spite of the wide use of the word worm, he also refers to the larvæ of the Lepidoptera as "grubs" ("Your butterfly was a grub," Cor., V. iv. I2) and as " caterpillars" whose destructive 


\section{ZOOLOGY IN TIME OF SHAKESPEARE 259}

effect on plants he well knew. Further, he distinguished between the sun-loving butterflies and the moths which as a rule fly by night, and between the dance of gnats in bright sunshine and their retirement to sheltered spots when the sun goes in.

Shakespeare understood a maggot. His knowledge of the bee and its habits, as shown by the phrase " thighs packed with wax," and by the wonderful, though in detail inaccurate, speech of Canterbury ("Hen. V.," I. ii. I87) about the bees who "teach the act of order to a peopled kingdom," was the expression of centuries of observation from pre-classical times onwards. We must never forget that our ancestors had no cane-sugar, no beet-sugar, no saccharine.

Although Shakespeare seems to distinguish between the spider's poison, which is in some few genera harmful if injected into the blood and harmless when swallowed, it is hardly probable that he or any one in his epoch had considered this physiological difference. Spiders and their webs and threads were of course used as constant illustrations, but only one born and bred in the country would put into the mouth of Thersites "I had rather be a tick in a sheep than such a valiant ignorance" ("Troilus," III. iii. 3r5). The 
scarpion he must only have known by hearsay, but of the louse and the mite he evidently had first-hand knowledge.

Shakespeare knew fish from two aspects, as a sportsman and as a consumer. The carp in his day, as still in Central Europe, was an important article of food, and fishponds were a source of wealth. He naturally knew more of fresh-water fishes than of salt. Dace he knew as bait for pike. Eels, one regrets to learn, were put " $i$ ' the paste alive" ("King Lear," II. iv. I24). He speaks of "this fool-gudgeon" and emphasises the traditional fecundity of the loach. Tench, trout, and salmon are all mentioned. The lastnamed, at times fresh-water, at other times marine, affords a transition to sea-fishes. In Elizabethan times there were no swift " carriers," no cold-storage, and the marine fishes consumed inland were such as could be "cured." The sprat, the pilchard, the stock-fish (salted cod), and above all the herring were evidently all common food. The great abundance of salted and cured fish was the direct consequence of the wholesome custom of "fasting " then enforced by the Church. In those times, as still in Russia and Scandinavia, pickled fish was a favourite relish. 
The "anchovies and sack after supper" (I "Hen. IV.," II. iv. 588), recommended by Peto, the "conger and fennel" ( 2 "Hen. IV.," IV. ii. 266), still a favourite combination in the Channel Islands, and the "soused gurnet," i.e., gurnard (I "Hen. IV.," IV. ii. I3) are still known.

The animals we now classify as amphibia were in Tudor times regarded as abhorrent. The " engendering of toads" was hated, and this harmless and in some respects attractive animal was looked upon as envenomed, foul, and poisonous. The toad or paddock was useful in a witches' broth, and the tailed amphibia (Urodela) newts and blind worms (or limbless lizards) were adjured to " do no harm." The tadpole, like the shrimp, is mentioned as a synonym for babe ("Titus Andronicus," IV. ii. 85).

No animals are more frequently alluded to in Shakespeare's plays than the serpent, the adder, the viper, and the asp (aspick). Their love of the sun, the beauty of their " painted skin," their forked tongues are referred to over and over again. The view that adders are deaf, which still survives, is probably based on the absence of external ears. Some of Shakespeare's characters thought the double tongue the instrument which 
stung, but York (3 “ Henry VI.," I. iv. II2) more correctly refers to the adder's tooth. Lear also (I. iv. 3II) appreciates the "serpent's tooth." The blind-worm, one of the few lizards mentioned, is obviously classed by Shakespeare with the Ophidia, but he shows on the other hand some acquaintance with the habits of the chameleon. The tortoise, the alligator, and "the mournful crocodile," whose traditional hypocrisy is referred to by the queen in 2 "Hen. VI.," III. i. 226 , complete the list of reptiles. Turtle in all places means the turtle-dove, not the chelonian.

Shakespeare also shows much knowledge of our sparse mammalian fauna; the weasel, the ferret, the hedgehog, the rabbit or coney, the otter, the polecat or fitchew which was thought to be very amorous, the deer then as now confined in parks or forests, cattle and other farmyard and domesticated animals were all within his ken. A curious allusion of Gonzalo's ("Tempest," III. iii. 45) to

" mountaineers,

Dewlapp'd like bulls, whose throats had hanging at 'em Wallets of "flesh,"

obviously refers to the goitre which was till recently common in the Peak district. 
ZOOLOGY IN TIME OF SHAKESPEARE 263

Shakespeare knew his dogs, and like all good men loved them: "she hath more qualities than a water-spaniel; which is much in a bare Christian " ("Two Gent.," III. i. 27I). He must have kept a water-spaniel.

One or two other expressions used by Shakespeare are now obsolete. Titania's "rere-mice" ("Mid. Night's Dream," II. ii. 4) are bats ; Falstaff's " gibbed cat" is a gelded cat ; the puttock, a kite; the moldwarp with which Glendower bored Hotspur is the mole (cf. the German Maulwurf) ; the "lugged bear" was a baited bear. Certain animals such as the lion, the leopard, the tiger, the panther, the bear, the camel, the rhinoceros, and perhaps the ostrich were known in Elizabethan times in menageries. The frequent and on the whole unflattering mention of the cat seems to indicate that Shakespeare was aware that many people, like Queen Victoria and Lord Roberts, have an instinctive dislike to that mammal ; he may have shared it.

To the category of recorded creatures belong the ape and monkey:

"The strain of man's bred out

Into baboon and monkey."

as Apemantus says ("Timon of A.," I. i. 260), and 
264 STUDIES IN INSECT LIFE, ETC.

the obvious resemblance between man and the lower primates excited in early times a very lively interest. I do not think, however, it would have occurred to Shakespeare, who was decidedly " on the side of the angels," to include them in one sub-order. His view, if less morphologically correct, was a higher one : "What a piece of work is a man! how noble in reason! how infinite in faculty! in form and moving how express and admirable ! in action how like an angel! in apprehension how like a god!" 


\section{Chapter X}

\section{THE REVIVAL OF SCIENCE IN THE SEVENTEENTH CENTURY*}

WiTH one or two exceptions-astronomy on the physical side, human anatomy on the biologicalthe reawakening in science lagged a century or more behind the renascence in literature and in art. What the leaders of thought and of practice in the arts of writing, of painting and of sculpture in western Europe were effecting in the latter part of the fifteenth and throughout the sixteenth century began to be paralleled in the investigations of the physical laws of nature only at the end of the sixteenth century and throughout the first three quarters of the seventeenth.

Writing broadly, we may say that, during the Stewart time, the sciences, as we now class them, were slowly but surely separating themselves out

* This address, revised and enlarged, formed part of a chapter in the eighth volume of The Cambridge History of English Literature. 
from the general mass of learning, segregating into secondary units; and, from a general amalgam of scientific knowledge, mathematics, astronomy, physics, chemistry, geology, mineralogy, zoology, botany, agriculture, even physiology (the offspring of anatomy and chemistry) were beginning to assert claims to individual and distinct existence. It was in the Stewart reigns that, in England at any rate, the specialist began to emerge from those who hitherto had "taken all knowledge to be " their " province."

Certain of the sciences, such as anatomy, physiology and, to a great extent, zoology and botany, had their inception in the art of medicine. But the last two owed much to the huntsman and the agriculturist. During the preceding century, the great Belgian anatomist Vesalius had broken loose from the bond of the written word which had strangled research for a thousand years, and had looked at the structure of the human body for himself; he taught what he could himself see and what he could show to his pupils. Under him, anatomy was the first of the natural sciences to break loose from the scholastic domination which had hitherto ever placed authority above experiment. 
As anatomy on the biological side, so astronomy on the physical, led the way. Copernicus had claimed that the sun was the centre of our system ; but it was not until the following century, when the truth of his views was mathematically proved, that, first, men of science, and, later, the world at large, abandoned the views of Ptolemy, which, like those of Aristotle, of Galen and of Hippocrates, had obsessed the learned world since classical times.

The great outburst of scientific inquiry which occurred during the seventeenth century was partly the result, and partly the cause, of the invention of numerous new methods and innumerable new instruments, by the use of which advance in natural knowledge was immensely facilitated. Early in the century (I6I4), Napier of Merchiston had made known his discovery of logarithms, and logarithmic tables were first published in I6I7. Seven years later, the slide rule, which to-day plays a large part in physical and engineering science, was invented by Edmund Gunter. Decimals were coming into use and, at the close of the sixteenth century, algebra was being written in the notation we still employ. William Gilbert, physician to Queen Elizabeth, published his 
268 STUDIES IN INSECT LIFE, ETC.

experiments on electricity and magnetism in the last year of the sixteenth century. Galileo was using his newly constructed telescope; and, for the first time, Jupiter's satellites, the mountains in the moon and Saturn's rings were seen by human eye. The barometer, the thermometer and the air pump, and, later, the compound microscope, all came into being at the earlier part of our period, and by the middle of the century were in the hands of whoever cared to use them. Pepys, in I664, acquired " a microscope and a scotoscope. For the first I did give him $£ 5$ Ios., a great price, but a most curious bauble it is, and he says, as good, nay, the best he knows in England. The other he gives me, and is of value; and a curious curiosity it is to discover objects in a dark room with."

Two years later, on August I9th, I666, " comes by agreement Mr. Reeves, bringing me a lantern " -it must have been a magic lantern - "with pictures in glass, to make strange things appear on a wall, very pretty."

As we pass from Elizabethan to Stewart times, we pass, in most branches of literature, from men of genius to men of talent, clever men, but not, to use a Germanism, epoch-making men. In 
science, however, where England led the world, the descent became an ascent. We leave Dr. Dee and Edward Kelly, and we arrive at Harvey and Newton.

The gap between the mediæval science which still obtained in Queen Elizabeth's time and the science of the Stewarts was bridged by Francis Bacon, in a way, but only in a way. He was a reformer of the scientific method. He was no innovator in the inductive method; others had preceded him, but he, from his great position, clearly pointed out that the writers and leaders of his time observed and recorded facts in favour of ideas other than those hitherto sanctioned by authority.

Bacon left a heritage to English science. His writings and his thoughts are not always clear, but he firmly held, and, with the authority which his personal eminence gave him, firmly proclaimed, that the careful and systematic investigation of natural phenomena and their accurate record would give to man a power in this world which, in his time, was hardly to be conceived. What he believed, what he preached, he did not practise. "I only sound the clarion, but I enter not into the battle"; and yet this is not wholly 
270 STUDIES IN INSECT LIFE, ETC.

true, for, on a wintry March day, I626, in the neighbourhood of Barnet, he caught the chill which ended his life while stuffing a fowl with snow, to see if cold would delay putrefaction. Harvey, who was working whilst Bacon was writing, said of him : "He writes philosophy like a Lord Chancellor." This, perhaps, is true, but his writings show him a man, weak and pitiful in some respects, yet with an abiding hope, a sustained object in life, one who sought through evil days and in adverse conditions "for the glory of God and the relief of man's estate."

Though Bacon did not make any one single advance in natural knowledge-though his precepts, as Whewell reminds us, " are now practically useless "-yet he used his great talents, his high position, to enforce upon the world a new method of wrenching from nature her secrets and, with tireless patience and untiring passion, impressed upon his contemporaries the conviction that there was " a new unexplored Kingdom of Knowledge within the reach and grasp of man, if he will be humble enough, and patient enough, and truthful enough to occupy it."

The most sublime of English poets survived our period by a few years. A comparison between 
Dante's and Milton's great epics affords some indication of the advance in knowledge of this world and in the outlook on a future state which measures the progress made between the Middle Ages and the seventeenth century. As a poet (and, indeed, often in other activities of his life) Milton stood above, or at least, outside, the stream of tendency of the times through which he lived. Yet, in his poems (not in his political tractatesthe most ephemeral of all literature) we see effects of the rising tide of science on literature.

Milton, one must never forget-and indeed, it is not easy to do so-was, for some years, a schoolmaster. He took a view of his profession which even now would be thought liberal; he advocated the teaching of medicine, agriculture and fortification, and, when studying the last of these, remarked that it would be "seasonable to learn the use of the Globes and all the maps." Like Lord Herbert of Cherbury, he held that the student should acquire some knowledge of medicine, he should know " the tempers, the humours, the seasons and how to manage a crudity." Himself a sufferer from gout, he learnt, at any rate, the lesson of moderation. Mathematics, in his curriculum, led to the "instrumental 


\section{STUDIES IN INSECT LIFE, ETC.}

science of Trigonometry and from thence to Fortification, Architecture, Enginry or Navigation."

At the time of the writing of "Paradise Lost," the learned had accepted the theory of Copernicus, although the mathematical proof afforded a few years later by Newton was still lacking. But the world at large still accepted the Ptolemaic system, a system which, as a schoolmaster, Milton taught. Mark Pattison has pointed out that these two "systems confront each other in the poem, in much the same relative position which they occupied in the mind of the public. The ordinary, habitual mode of speaking of celestial phenomena is Ptolemaic*; the conscious or doctrinal exposition of the same phenomena is Copernican. †"

But the incongruity between these two statements is no greater than will be found to-day in authors writing of subjects still sub judice. Further, we must not forget that Milton never saw either of his great epics in writing or in print. His power of impressing his visions on the world was, however, such that Huxley held that it

* Mark Pattison cites "Paradise Lost," VII. 339-356 ; III. 420-48I. And yet, in I639, Milton had visited Galileo.

$\dagger$ See ibid., VII. 77, I22-I40. 
was not the cosmogony of Genesis but the cosmogony of Milton which had enthralled and misled the world.

More distinctly than in his epics, Milton, in his history, showed a leaning to the scientific method. Firth has lately told us that "his conclusions are roughly those of modern scholars, and his reasoning practically that of a scientific historian." In one respect, however, he was less than lukewarm. He had no sympathy with antiquarian researches and sneered at those "who take pleasure to be all their lifetime raking the foundations of old abbeys and cathedrals."

To turn to other evidence, the better diaries of any age afford us, when faithfully written, as fair a clue as do the dramatists of the average intelligent man's attitude towards the 'general outlook of humanity on the problems of his age, as they presented themselves to society at large. The seventeenth century was unusually rich in volumes of autobiography and in diaries which the reading world will not readily let die. The autobiography of the complaisant Lord Herbert of Cherbury gives an interesting account of the education of a highly-born youth at the end of the sixteenth and the beginning of the seven- 
teenth century. Lord Herbert seems to have had a fair knowledge of Latin and Greek and of logic when, in his thirteenth year, he went up to University College, Oxford. Later, he " did attain the knowledge of the French, Italian and Spanish languages," and, also, learnt to sing his part at first sight in music and to play on the lute. He approved of "so much logic as to enable men to distinguish between truth and falsehood and help them to discover fallacies, sophisms and that which the schoolmen call vicious arguments"; and this, he considered, should be followed by "some good sum of philosophy." He held it also requisite to study geography, and this in no narrow sense, laying stress upon the methods of government, religions and manners of the several states as well as on their relationships inter se and their policies. Though he advocated an acquaintance with "the use of the celestial globes," he did " not conceive yet the knowledge of judicial astronomy so necessary, but only for general predictions; particular events being neither intended by nor collected out of the stars." Arithmetic and geometry he thought fit to learn, as being most useful for keeping accounts and enabling a gentleman to understand fortifications. 
Perhaps the most characteristic feature of Lord Herbert's acquirements was his knowledge of medicine and subjects allied thereto. $\mathrm{He}$ conceived it a " fine study, and worthy a gentleman to be a good botanic, that so he may know the nature of all herbs and plants." Further, "it will become a gentleman to have some knowledge in medecine, especially the diagnostic part " ; and he urged that a gentleman should know how to make medicines himself. He gives us a list of the "pharmacopæias and anechodalies" which he has in his own library, and certainly he had a knowledge of anatomy and of the healing arthe refers to a wound which penetrated to his father's "pia mater," a membrane for a mention of which we should look in vain among the records of modern ambassadors and gentlemen of the court. His knowledge, however, was entirely empirical and founded on the writings of Paracelsus and his followers; nevertheless, he prides himself on the cures he effected, and, if one can trust the veracity of so self-satisfied an amateur physician, they certainly fall but little short of the miraculous.

John Evelyn, another example of a well-to-do and widely cultivated man of the world, was 
276 STUDIES IN INSECT LIFE, ETC.

acquainted with several foreign languages, including Spanish and German, and was interested in hieroglyphics. He studied medicine in I645 at Padua, and there acquired those " rare tables of veins and nerves" which he afterwards gave to the Royal Society; attended Lefevre's course of chemistry at Paris in 1647; was skilled in more than one musical instrument, learned dancing and, above all, devoted himself to horticulture.

When travelling abroad, he made a point of visiting the "cabinets" of collectors, for, at that time, public museums, which, in fact, grew out of these cabinets, were non-existent. The following quotation records the sort of curiosities at which men marvelled in the year I645 :-

"Feb. 4th.-We were invited to the collection of exotic rarities in the museum of Ferdinando Imperati, a Neapolitan nobleman, and one of the most observable palaces in the citty, the repository of incomparable rarities. Amongst the naturall herbals most remarkable was the Byssus marina and Pinna marina; the male and female cameleon; an Onacratulus; an extraordinary greate crocodile; some of the Orcades Anates, held here for a great rarity ; likewise a salamander ; 
the male and female Manucodiata, the male having an hollow in the back, in $\mathrm{w}^{\text {ch }}$ 'tis reported the female both layes and hatches her egg; the mandragoras of both sexes; Papyrus made of severall reedes, and some of silke; tables of the rinds of trees written with Japoniq characters; another of the branches of palme; many Indian fruites; a chrystal that had a quantity of uncongealed water within its cavity; a petrified fisher's net; divers sorts of tarantulas, being a monstrous spider with lark-like clawes, and somewhat bigger."

But Evelyn's chief contribution to science, as already indicated, was horticultural. $\mathrm{He}$ was devoted to his garden, and, both at his native Wotton, and, later, at Sayes Court, Deptford, . spent much time in planting and planning landscape gardens, then much the fashion.

In the middle of the sixteenth century, the fact that " nitre" promoted the growth of plants was beginning to be recognised. Sir Kenelm Digby and the young Oxonian John Mayow, experimented de Sal-Nitro; and, in I675, Evelyn writes: "I firmly believe that where saltpetre can be obtained in plenty we should not need to 
find other composts to ameliorate our ground." His well-known "Sylva," published in I664, had an immediate and a widespread effect, and was, for many years, the standard book on the subject of the culture of trees. It is held to be responsible for a great outbreak of tree-planting. The introduction to Nisbet's edition gives figures which demonstrate the shortage in the available supply of oak timber during the seventeenth century. The charm of Evelyn's style and the practical nature of his book, which ran into four editions before the author's death, arrested this decline (" be aye sticking in a tree; it will be growing, Jock, when y're sleeping " as the laird of Dumbiedykes counselled his son), and to the "Sylva" of John Evelyn is largely due the fact that the oak timber used for the British ships which fought the French in the eighteenth century sufficed, but barely sufficed, for the national needs.

Pepys, whose naïve and frank self-revelations have made him the most popular and the most frequently read of diarists, was not quite of the same class of student to which Lord Herbert of Cherbury or John Evelyn belonged. But, gifted as he was with an undying and insatiable curiosity, nothing was too trivial or too odd for his notice 
and his record; [and, being an exceptionally able and hard-working government servant, he took great interest in anything which was likely to affect the Navy. He discoursed with the ingenious Dr. Kuffler " about his design to blow up ships," noticed "the strange nature of the seawater in a dark night, that it seemed like fire upon every stroke of the oar "- -an effect due, of course, to phosphorescent organisms floating near the surface-and interested himself incessantly in marine matters. His troubled eyesight and his love of music account for the attention he paid to optical appliances, the structure of the eye, musical instruments of every kind and musical notation; for this last, he seems to have invented a mechanical means of composing which is still preserved at Magdalene College, but which no one now quite understands.

Physiology and mortuary objects had, for him, an interest which was almost morbid. $\mathrm{He}$ is told that " negroes drounded look white, and lose their blackness, which I never heard before," describes how "one of a great family was ... hanged with a silken halter... of his own preparing, not for the honour only" but because it strangles more quickly. He attended regularly 
the early meetings of the Royal Society at Gresham College, and showed the liveliest interest in various investigations on the transfusion of blood, respiration under reduced air pressure and many other ingenious experiments and observations by Sir George Ent and others. On January 20th, I665, he took home "Micrographia," Hooke's book on microscopy- " a most excellent piece, of which I am very proud."

Although Pepys had no scientific traininghe only began to learn the multiplication table when he was in his thirtieth year, but, later, took the keenest pleasure in teaching it to Mrs. Pepys-he, nevertheless, attained to the Presidentship of the Royal Society. He had always delighted in the company of "the virtuosos" and, in 1662, three years after he began to study arithmetic, he was admitted a fellow of theirthe Royal-Society. In I68I, he was elected president. This post he owed, not to any genius for science, or to any great invention or generalisation, but to his very exceptional powers as an organiser and as a man of business, to his integrity and to the abiding interest he ever showed in the cause of the advancement of knowledge.

If we pass from the interest taken in scientific 


\section{THE REVIVAL OF SCIENCE}

progress by men of superior intelligence to the obstacles opposed to it by popular ignorance and superstition, we are brought face to face with the long-lived crew of witches, wizards and alchemists. It is often said that the more rationalistic outlook of the seventeenth century, due to Hobbes and others, did much to discredit these practitioners. But the observant dwellers in our British cities or remote country villages, pestered as they are with advertisements of those who practise palmistry, and of those who predict the future by crystal-gazing or by the fall of sand, of followers of the sporting prophet, and of far more presumptuous and more dangerous impostors, or confronted by the silent, indomitable belief of the rustic in the witchery of his ancestors, may well hold the opinion that the stock of superstition is a constant stock and permeates now, as it did in Elizabeth's time, every class of society. What improvement there was in the seventeenth century, and it is extremely doubtful if there was much, was largely due to the advent of James I. and the later rise of puritanism, associated as they were with the most cruel and most inhuman torture of sorcerers. When the alchemist and the astrologer ran the risk of suffering as a sorcerer or 
a warlock, he paused before publicly embarking on that trade.

Under the Tudors, the laws against witchcraft were milder than those of other countries, but, under James I., these laws were repealed and he himself took-as he had done before in Scotland -an active part in this cruel and senseless persecution. During the first eighty years of the seventeenth century, no less than 70,000 men and women are said to have been executed for alleged offences under the new act. The king even wrote a book on demonology, attacking the more sensible and reasonable views of Scot and Weir. It must be remembered, however, that, in these times, the generality of learned and able men believed in the maleficent effects of sorcery and the black art. The bench of bishops and the bench of judges alike took part in what seems to us a hideous and wanton brutality. Even so great a writer as Sir Thomas Browne, who tells us, "for the sorrows of others he has quick sympathy," gave evidence against two unhappy women charged before Sir Matthew Hale at Bury St. Edmunds, and his evidence helped to secure their iniquitous conviction.

Browne, like many of his day, was a firm 
believer in horoscopes-" I was born in the planetary hour of Saturn and I think I have a piece of that leaden planet in me." $\mathrm{He}$ was, however, perhaps a little in advance of some of his contemporaries; at any rate, he recognised that foretellings based on star-gazing do not always "make good." "We deny not the influence of the stars but often suspect the due application thereof." During the civil war, both sides used astrologers and acted on their prognostications; but, on the whole, the firm belief that future events could be foretold by a study of the planetary system was waning. "They" (i.e., the stars) "incline but do not compel . . . and so gently incline that a wise man may resist them; sapiens dominabitur astris : they rule, but God rules them."* This was said by Robert Burton, and it probably represents the average opinion of the more educated in our period.

The part played by alchemy in the life of the times can be judged by Ben Jonson's "Alchemist," first acted in I6ro, which affords a true insight into the fashionable craze of the time. The play was constantly presented from that date until

* "Anatomy of Melancholy," Part I., Sec. II., Mem. I, Sec. IV. 
the closing of the theatres, and, on the Restoration, was one of the first plays to be revived. Jonson certainly had mastered the jargon of this form of quackery, and showed a profound knowledge of the art of its professors. In "Epicoene, or the Silent Woman," he refers to the love philtres of one Forman, a most flagrant rascal who was mixed up with the Overbury trial.

It has been said that a competent man of science should be able to put into language "understanded of the people" any problem, no matter how complex, at which he is working. This seems hardly possible in the twentieth century. To explain to a trained histologist double $\theta$ functions or to a skilled mathematician the intricacies of karyokinesis would take a very long time. The introduction in all the sciences of technical words is due not to any spirit of perverseness on the part of modern savants; these terms, long as they usually are, serve as the shorthand of science. In the Stewart times, however, an investigator could explain in simple language to his friends what he was doing, and the advance of natural science was keenly followed by all sorts and conditions of men.

Whatever were the political and moral de- 
ficiencies of the Stewart kings, no one of them lacked intelligence in things artistic and scientific. The pictures at Windsor and at Buckingham Palace which the nation owes to Charles I. and Charles II. are only approached by those it owes to the knowledge and taste of Queen Victoria's consort. At Whitehall, Charles II. had his "little elaboratory, under his closet, a pretty place,"* and was working there but a day or two before his death, his illness disinclining him for his wonted exercise. The King took a curious interest in anatomy; on May IIth, I663, Pierce, the surgeon, tells Pepys "that the other day Dr. Clerke and he did dissect two bodies, a man and a.woman, before the King with which the King was highly pleased." Pepys also records, February I7th, I662-3, on the authority of Edward Pickering, another story of a dissection in the royal closet by the King's own hands.

It has, I think, seldom been pointed out that Charles II.'s ancestry accounts for many of his qualities and especially for his interest in science. He was very unlike his father, but his mother was the daughter of a Medici princess, and the

* Pepys, January I6th, I669. 
characteristics of that family are strongly marked in the "merry monarch." His gaiety and wit and his skill in money matters when he chose to apply himself, all bring to mind the Italian family from which he sprang. Even the swarthy complexion of Charles II. was probably due to his Italian blood, and his fondness for outdoor sports is another trait which is often observed in the Medici themselves. There is an old engraving of a portrait of Lorenzo (d. I648), the brother of Cosimo II., which shows an astonishing resemblance to Charles II.; and it is interesting to remember that Cosimo II. earned his chief claim to the gratitude of posterity by his courageous encouragement, protection and support of Galileo, who owed to him the opportunity and means of making his famous astronomical discoveries.

Another royal personage, Prince Rupert, " full of spirit and action, full of observation and judge-ment," about this time invented his "chemical glasses which break all to dust by breaking off a little small end: which is a great mystery to me."* He had, says Gramont, quelques talens for chemistry and invented a new method for

* Pepys, January I3th, r662. 
making gunpowder, for making "hails hot" and for boring cannon. His traditional invention of the almost lost art of mezzotint is probably due to the fact that, at an early date, the real inventor, Ludwig von Siegen, explained to him his process and that Prince Rupert demonstrated with his own hands this new method of engraving to Evelyn.

Another aristocratic inventor, Edward Somerset, second Marquis of Worcester, has received more credit than he deserved. He was interested in mechanics and employed a skilled mechanician, one Kaltoff, in his laboratory, but his claims to have invented a steam-engine do not bear critical investigation, and his well-known "Century of Inventions" does not rise to the level of "The Boy's Own Book" of the last century. Many of his suggestions, though ingenious, are based on fallacies, and comparatively few of them were practical.

A curiously versatile amateur in science was Sir Kenelm Digby. Like most prominent men of his time, he intervened in theological questions, besides playing an active part in public affairs. He was an original member of the Royal Society, but, although he is reported to have been the first 
to record the importance of the "vital air" we now call it oxygen-to plants, and although he had gifts of observation, his work lay largely in the paths of alchemy and astrology, and he seems to have had recourse to a lively imagination in estimating the results of his experiments. He trafficked in the transmutation of metals, and his name was long associated with a certain "powder of sympathy" which, like the "absent treatment " of the twentieth century practitioners of Christian science, "acted at a distance." Evelyn looked on him as a quack, "a teller of strange things," and Lady Fanshawe refers to his infirmity of lying; he was certainly a great talker. Still, other men of his epoch spoke well of him, and his conversation was doubtless stimulating if profuse.

In mathematics, John Wallis was, to some extent, a forerunner of Newton. At Felsted School and at Emmanuel College, he received the curiously wide education of his age. $\mathrm{He}$ was a skilled linguist; although he had taken holy orders, he was the first of Francis Glisson's pupils to proclaim in public Harvey's discovery on the circulation of the blood, but his bent was towards mathematics, and he possessed an 
extraordinary memory for figures. His "Arithmetica Infinitorum" is described as "the most stimulating mathematical work so far published in England." It contained the germs of the differential calculus, and it suggested to Newton, who " read it with delight," the binomial theorem. In it $\pi$ was evaluated, and it must not be forgotten that to Wallis we owe the symbol for infinity, $\infty$. Living in troublesome times, under many rulers, he contrived, not without some loss of popularity, to remain on good terms with all. His services were, indeed, indispensable to a succession of Governments, for he had a power of deciphering which was almost miraculous. Cromwell, who seems to have had a great respect for his powers, appointed him Savilian professor of geometry at Oxford in I649.

Another mathematical ecclesiastic was Seth Ward, Bishop of Exeter and afterwards of Salisbury. Ward was educated at Sidney Sussex College, and, in 1643 , was chosen as mathematical lecturer to the University of Cambridge. But, like Wallis, he was appointed, and in the same year, to a Savilian professorship, that of astronomy -another instance, not uncommon at the time, of men educated at Cambridge but recognised and 
promoted at Oxford. He took the place of the ejected John Greaves, who magnanimously used his influence in his successor's favour. Ward was renowned as a preacher; but his later fame rested chiefly on his contributions to the science of astronomy, and he is remembered in the world of science mainly for his theory of planetary motion. Ward and Wallis-but the burden of the attack was borne by the latter-laid bare Hobbes's attempted proof of the squaring of the circle; there was also a little controversy " on the duplication of the cube," and mixed up with these criticisms in the realm of pure reason were political motives. Hobbes had not begun to study Euclid until he was forty; and, after Sir Henry Savile had founded his professorships at Oxford, Wood says that not a few of the foolish gentry " kept back their sons" in order not "to have them smutted by the black art "- -so great was the fear and the ignorance of the powers of mathematics. Ward was a pluralist, as was the manner of the times, and Burnet tells us "he was a profound statesman but a very indifferent clergyman." Yet, what money he got he lavishly spent on ecclesiastical and other purposes. As Bishop of Exeter, he restored, at the cost of $£ 25,000$, the 
cathedral; repaired the palace; considerably increased the value of the poorer benefices of his diocese and of the prebends of his cathedral; and gave a considerable sum of money towards the cost of making the river navigable from his cathedral city to the sea. He founded the Seth Ward almshouses at Salisbury, and he gave certain farms and fee-farm rents for scholarships at Christ's College, Cambridge.

Like the distinguished mathematicians just mentioned, Isaac Newton took a keen interest in certain forms of theology current in his day; but in his intellectual powers he surpassed not only them but all living mathematicians and those. who lived after him. His supreme genius has ensured him a place in the very small list of the world's thinkers of the first order. He, too, exercised a certain influence in affairs, and, during his later years, he took a keen interest in theological speculations; but his activities in these fields are completely overshadowed by the far-reaching importance of his great discoveries as a natural philosopher and a mathematician. As the discoverer of the decomposition of white light in the spectrum, he may be regarded as the founder of the modern science of optics. His discovery 
292 STUDIES IN INSECT LIFE, ETC.

of the law of gravitation, and his application of it to the explanation of Kepler's laws of planetary motion and of the principal inequalities in the orbital motion of the moon, made him the founder of the science of gravitational astronomy. His discovery of the method of fluxions entitles him to rank with Leibniz as one of the founders of mathematical analysis. All these great discoveries gave rise to long and sometimes acrimonious controversies among his contemporaries, relating both to the subjects themselves and to priority of discovery. In a letter to Halley referring to one of these disputes, Newton writes:

"Philosophy is such an impertinently litigious lady, that a man has as good be engaged in lawsuits, as have to do with her. I found it so formerly, and now I am no sooner come near her again, but she gives me warning."

His chief work, " Principia," has been described by Dean Peacock as " the greatest single triumph of the human mind."*

* Newton held the office of President of the Royal Society for the last twenty-five years of his life, a period exceeded only in the case of one President, Sir Joseph Banks. 
The second man of outstanding genius in British science in the seventeenth century was Harvey, who, like Newton, worked in one of the two sciences which, in Stewart times, were, to some extent, ahead of all the others. Harvey, "the little choleric man" as Aubrey calls him, was educated at Cambridge and at Padua and was in his thirty-eighth year when, in his lectures on anatomy, he expounded his new doctrine of the circulation of the blood to the College of Physicians, although his "Exercitatio" on this subject did not appear till I628. His notes for the lectures are now in the British Museum. He was physician to Charles I.; and it is on record how, during the battle of Edgehill, he looked after the young princes as he sat reading a book under a hedge a little removed from the fight.

In the chain of evidence of his convincing demonstration of the circulation of the blood, one link, only to be supplied by the invention of the compound microscope, was missing. This, the discovery of the capillaries, was due to Malpighi, who was amongst the earliest anatomists to apply the compound microscope to animal tissues. Still, as Dryden has it, 
"The circling streams once thought but pools of blood(Whether life's fuel or the body's food),

From dark oblivion Harvey's name shall save."*

Harvey was happy in two respects as regards his discovery. It was, in the main and especially in England, recognised as proven in his own lifetime, and, again, no one of credit claimed or asserted the claim of others to priority. In research, all inquirers stand on steps others have built up; but, in this, the most important of single contributions to physiology, the credit is Harvey's and almost Harvey's alone. His other great work, "Exercitationes de Generatione Animalium," is of secondary importance. It shows marvellous powers of observation and very laborious research ; but, although, to a great extent, it led the way in embryology, it was shortly superseded by works of those who had the compound microscope at their command. Cowley, a man of wide culture, wrote an "Ode on Harvey" in which his achievement was contrasted with a failing common to scientific men of his own time, and, so far as we can see, of all time:

* Epistle to Dr. Charleton. 


\section{THE REVIVAL OF SCIENCE}

“ Thus Harvey sought for Truth in Truth's own Book The Creatures, which by God Himself was writ ;

And wisely thought 'twas fit, Not to read Comments only upon it, But on th' original it self to look. Methinks in Arts great Circle others stand

Lock't up together, Hand in Hand,

Every one leads as he is led,

The same bare path they tread, A Dance like Fairies a Fantastick round, But neither change their motion, nor their ground: Had Harvey to this Road confin'd his wit, His noble Circle of the Blood had been untrodden yet."

Harvey's death is recorded in a characteristic seventeenth century sentence, taken from the unpublished pages of Baldwin Harvey's "Bustorum Aliquot Reliquiæ " :

"Of William Harvey, the most fortunate anatomist, the blood ceased to move on the third day of the Ides of June, in the year 1657 , the continuous movement of which in all men, moreover, he had most truly asserted . . .

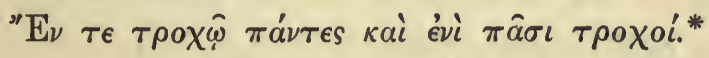

Among other great physiologists and physicians, Sir Theodore Turquet de Mayerne (godson of

* The writer is indebted for this quotation to Dr. Norman Moore's "History of the Study of Medicine in the British Isles," Oxford, I908. 
296 STUDIES IN INSECT LIFE, ETC.

Theodore Beza), who settled in London in I6II, has left us "Notes" of the diseases of the great which, to the medically minded, are of the greatest interest. He almost diagnosed enteric, and his observations on the fatal illness of Henry, Prince of Wales, and the memoir he drew up in I623 on the health of James I., alike leave little to be desired in completeness or in accuracy of detail.

Before bringing to a close these short notices of those who studied and wrote on the human body, whole or diseased, a few lines must be given to John Mayow of Oxford, who followed the law, " especially in the summer time at Bath." Yet, from his contributions to science, one might well suppose that he had devoted his whole time to research in chemistry and physiology. He it was who showed that, in respiration, not the whole air but a part only of the air breathed in takes an active part in respiration, though he called this part "by a different name, he meant what we now call oxygen."*

Thomas Sydenham was one of the first physicians who was convinced of the importance of constant and prolonged observation at the bedside of the

* Foster, Sir Michael, "The History of Physiology," Cambridge, Igor. 
patient. He passed by all authority but one" the divine old man Hippocrates," whose medicine rested also on observation. $\mathrm{He}$, first in England, "attempted to arrive at general laws about the prevalence and the course and the treatment of disease from clinical observation." He was essentially a physician occupied in diagnosis, treatment and prognosis. When he was but twenty-five years old, he began to suffer from gout, and his personal experience enabled him to write a classic on this disease, which is even now unsurpassed.

Francis Glisson, like Sydenham, was essentially English in his upbringing, and did not owe anything to foreign education. His work on the liver has made "Glisson's capsule" known to every medical student, and he wrote an authoritative book on rickets. He, like Harvey, was educated at Gonville and Caius College, and, in I636, became regius professor of physic at Cambridge, but the greater part of his life he spent at Colchester. We must perforce pass by the fashionable Thomas Willis and his more capable assistant Richard Lower, with Sir George Ent, and others.

The invention of the microscope mentioned 
298 STUDIES IN INSECT LIFE, ETC.

above gave a great impetus to the study of the anatomical structure of plants and later of animals; and in relation to this we must not overlook the work of Nehemiah Grew (I64I-I7I2) who, with the Italian Malpighi, may be considered a co-founder of the science of plantanatomy. He was the son of a clergyman, who, as clergymen were apt to do in those days, got into trouble under the Act of Uniformity.

Nehemiah studied at Pembroke Hall, Cambridge, and afterwards took his Doctor's Degree at Leiden. He published numerous treatises dealing with the anatomy of vegetables, and with the comparative anatomy of trunks, roots, etc., illustrated with admirable and somewhat diagrammatic plates. Although essentially an anatomist he made certain investigations into plant physiology and suggested many more. Perhaps his most interesting contribution to the science, however, was his discovery that flowering plants, like animals, have male and female sexes. It seems odd to reflect that this discovery is only about 250 years old. When Grew began to work the study of botany was in a very neglected condition-the old herbal had ceased to interest, and with its contemporary, the bestiary, was 
disappearing from current use, and the work of some of Grew's contemporaries, notably Robert Morison and John Ray, hastened their disappearance. Of these two systematists Ray was, on the whole, the more successful : Morison's efforts at classifying the vegetable kingdom receiving much criticism at the time and by no means came up to the great expectations that he himself had formed of them. Ray's system at any rate obtained in England until the latter half of the eighteenth century, when it was gradually replaced by the Linnaean method of classification.

But Ray has other claims on our regard. $\mathrm{He}$ and Francis Willughby, both of Trinity College, Cambridge, attacked a similar problem in the animal kingdom. Willughby was the only son of wealthy and titled parents, whilst Ray was the son of a village blacksmith. But the older Universities are great levellers, and Ray succeeded in infusing his fellow student at Cambridge with his own genuine love for natural history. With Willughby he started out on his methodical investigations of animals and plants in all the accessible parts of the world. Willughby died young and bequeathed a small benefaction and his manuscripts to his older friend. After 
his death Ray undertook to revise and complete his "Ornithology," and therein paid great attention to the internal anatomy and to the habits and to the eggs of most of the birds he described. All the innumerable fables which had passed from book to book in the old bestiaries disappeared, for Ray ever showed a healthy scepticism with regard to the marvellous. $\mathrm{He}$, further, edited Willughby's "History of Fishes," but perpetuated the mistake of his predecessors in retaining whales amongst that group. In a rather rationalistic mood he argues that the fish which swallowed Jonah must have been a shark. Perhaps the weakest of his three great histories the History of Insects-was due to the fact that Ray edited it in his old age.

Ray was always a fine field naturalist, and his catalogues of Cambridgeshire plants long remained a classic. We may perhaps sum up the contributions of this great naturalist in the words of Professor Miall: “During his long and strenuous life he introduced many lasting improvements-fuller descriptions, better definitions, better associations, better sequences. $\mathrm{He}$ strove to rest his distinctions upon knowledge of structure, which he personally investigated at 
every opportunity. ... His greatest single improvement was the division of the herbs into Monocotyledons and Dicotyledons. . . . He made things much easier for Linnaeus, as did Linnaeus in his turn for naturalists who now smile at his mistakes. Both were capable of proposing haphazard classifications, a fact which need not surprise us, when we reflect how much reason we have to suspect that the best arrangements of birds, teleostean fishes, insects and flowering plants known to our own generation need to be largely recast."

Great as were the seventeenth century philosophers in the biological and medical sciences, they were paralleled if not surpassed by workers on the physical and mathematical side. Robert Boyle-who has been described as the Father of Chemistry and Brother of the Earl of Corkwas, even as a boy of eighteen, one of the leaders in the comparatively new pursuit of experimental science. His first love was chemistry, "Vulcan has so transported and bewitched me as to make me fancy my laboratory a kind of Elysium," thus he wrote in I649. A few years later ( $1652-3)$, in Ireland, where he was called to look after the family estates, he found it " hard to have any 
Hermetic thoughts," and occupied his mind with anatomy and confirming Harvey's discovery of the circulation of the blood. A year later, he settled at Oxford, where he arranged a laboratory and had as assistant Robert Hooke. Meetings were held alternately, at Boyle's lodgings and at John Wilkins's lodge at Wadham, and were frequented by Seth Ward and Christopher Wren and by many others.

Stimulated by Otto von Guericke's contrivance for exhausting air from a vessel, Boyle, aided by Hooke, invented what was called the "Machina Boyliana," which comprised the essentials of the air-pump of to-day. At this time, Boyle busied himself with the weight, with the pressure and with the elasticity of air-the part it played in respiration and in acoustics. Like Newton, he took a deep interest in theology, and not only spent considerable sums in translating the Bible into foreign tongues, but learnt Greek, Hebrew, Syriac and Chaldee so that he might read it at first hand. He was, indeed, a very notable character. Suffering under continued ill-health, with weak eyes, a slight stammer, and a memory treacherous to the last degree, he was yet one of the most helpful of friends and universally 
popular alike at the court of three kings, and in the society of men of letters, men of business and men of science. In spite of the fact that he was the first to distinguish a mixture from a compound, to define an element, to prepare hydrogen though he did not recognise its nature, he had in him the touch of an amateur but an amateur of genius. His style in writing was unusually prolix and he seldom followed out his discoveries to their ultimate end.

It was men such as these that re-established the Royal Society in I66o. Exactly a century earlier, the first scientific society, the Academia Secretorum Naturae of Naples had its origin. This was followed by several others in Italy and in France, most of them but shortlived. Among English or Teutonic folk, the Royal Society was the earliest to appear, and, even if we include the scientific societies of the world, it has had the most continuous existence. Indeed, before its birth, it underwent a long period of incubation, and its inception was in reality in 1645. At that date, a society known as the Philosophical, or, as Boyle called it, the "Invisible," college came into being, which met from time to time at Gresham College and elsewhere in London. During 
304 STUDIES IN INSECT LIFE, ETC.

the civil war, this society was split in two, some members meeting in London, some at Oxford, but the meetings, wherever held, were at irregular intervals. On the Restoration, the meetings were resumed in London and, in 1662 , the society received the royal charter.

Of all the poets of the time, Cowley took, perhaps, the greatest interest in science. He had, indeed, like Evelyn and at about the same date, developed a plan for the institution of a college of science. Evelyn explains his scheme in a letter addressed to Robert Boyle, dated September 3rd, I659, from Sayes Court, which contains minute details as to the buildings, the maintenance, and the government of his college, the inmates of which were to "preserve science and cultivate themselves." Cowley's scheme was also elaborately thought out, and had the original and admirable suggestion that, out of the twenty salaried professors, sixteen should be always resident and four always travelling in the four quarters of the world, in order that they might "give a constant account of all things that belong to the learning and especially Natural Experimental Philosophy of those parts." To his "Philosophical Colledge" was to be attached 
a school of two hundred boys. Both these schemes, according to Bishop Sprat, hastened the foundation of the Royal Society, of which both projectors were original members.

Cowley's poems were greatly admired during his lifetime, later critics have considered him affected, perhaps because, like Donne, he understood, and was not afraid to use, the technical language of the schools. We have quoted some of his lines on Harvey, and may add a few from the ode with which he greeted the birth of the Royal Society :

"From . . . all long Errors of the way, In which our wand'ring Praedecessors went, And like th' old Hebrewes many years did stray

In Desarts but of small extent, Bacon, like Moses, led us forth at last

The barren Wilderness he past,

Did on the very Border stand

Of the blest promis'd Land, And from the Mountains Top of his Exalted Wit,

Saw it himself, and shew'd us it. But Life did never to one Man allow Time to Discover Worlds, and Conquer too ; Nor can so short a Line sufficient be To fadome the vast depths of Natures Sea :

The work he did we ought t' admire And were unjust if we should more require From his few years, divided 'twixt th' Excess Of low Affliction, and high Happiness. 
For who on things remote can fix his sight, That's alwayes in a Triumph, or a Fight?"

Donne, who, like Cowley, indulged in quaint poetical conceits and who founded a new school of poetry, abjuring classical conventions and classical characters, and treating of topics and objects of everyday life, was not afraid of realism. "Upon common objects," Dr. Johnson tells us, he was " unnecessarily and unpoetically subtle." Time limits us to one quotation:

"Marke but this flea, and marke in this, How little that which thou deny'st me is ;

It suck'd me first, and now sucks thee, And in this flea, our two bloods mingled bee."

Donne did not of course foresee the appalling part that these insects, by the habits he mentions, play in the spread of such diseases as bubonic plague and many epizootics in animals.

The dramatists of the Stewart period hardly afford us the help we need in estimating the position occupied by science and by men of science in the world of the seventeenth century. The astrologer and the alchemist were the stock characters of the drama of everyday life, just as the company promoter and the multimillionaire are now. "The Gentlemen of Trinity 


\section{THE REVIVAL OF SCIENCE}

Colledge " presented " before the King's Majesty" a comedy entitled "Albumazar," which takes its name from the chief character, an astrologer, a very arrant knave, and the type of the false man of science. This play, originally printed in $16 \mathrm{I} 5$, was soon forgotten, but it was revived in 1688 and met with great success.

Samuel Butler, who was not a fellow of the Royal Society for some reason difficult to explain, spent much time in attacking it. He wrote his entertaining satire on the virtuosi entitled "The Elephant in the Moon " in short verse, and was so pleased with it that he wrote it over again in long verse. Though this "Satire upon the Royal Society" remains a fragment, enough of it is extant to show Butler did not appreciate what even in these days is not always appreciated, that the minute investigation of subjects and objects which to the ordinary man seem trivial and vain often lead to discoveries of the profoundest import to mankind.

Ben Jonson, with his flair for presenting what zoologists call "type species," showed, as has been seen, in his "Alchemist" an unusual, but a thorough, mastery of the half scientific and half quack jargon of the craft, so that this play is a 
308 STUDIES IN INSECT LIFE, ETC.

quarry for all interested in the history of chemical and physical studies. To the play-writer of the time, the man of science or of pseudo-science

-was a vague, peevish pedant, much occupied with physiognomies, dreams and fantastic ideas as to the properties and powers of various substances. But there seems to have been a clear distinction drawn between a real and a false astrology, as is shown in Dryden's “An Evening's Love" (r668).

The above is but an all too brief record of the founding of modern science by our ancestors under the Stewarts. Not until our own times did we see a parallel awakening in the Scientific Spirit.

May I in conclusion say again in the sonorous prose of Queen Elizabeth's age, there is now as then "a new unexplored Kingdom of Knowledge within the reach and grasp of man, if he will be humble enough, and patient enough, and truthful enough to occupy it." 



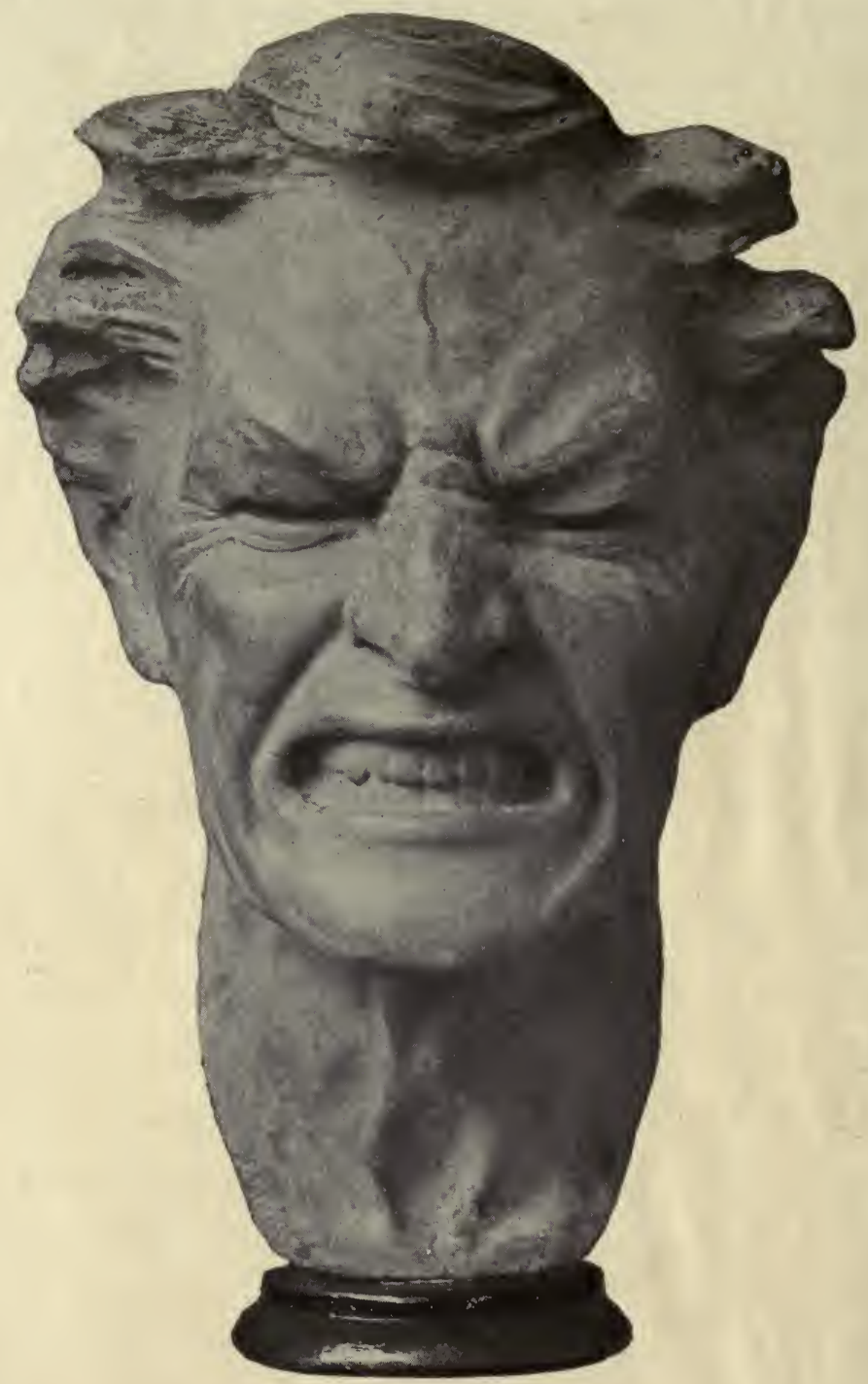

Bronze Mask, showing the expression of the face in violent effort and fatigue, by Professor R. Tait Mackenzie. 


\section{Chapter XI}

\section{HATE}

"In peace there's nothing so becomes a man As modest stillness and humility:

But when the blast of war blows in our ears, Then imitate the action of the tiger; Stiffen the sinews, summon up the blood, Then lend the eye a terrible aspect; Now set the teeth, and stretch the nostril wide, Hold hard the breath, and bend up every spirit To his full height! On, on, you noblest English."

"Henry V."-Act III. Sc. i.

THERE has recently been an extraordinary recrudescence of hatred throughout what we used to think was a civilised world. The active and patent stock of hatred in humanity has never been constant, it ebbs from time to time and then wells up again. The immobilised, the potential stock is, however, limitless. Indications indeed are not wanting that hatred has in historical times lessened both in quality and in quantity. In the magnificent Psalm of David (cxxxix.) the author critically examines whether 


\section{Io STUDIES IN INSECT LIFE, ETC.}

he is a sufficiently perfect hater: whether he really hates in the true spirit set forth so eloquently in Psalm cix. But as we pass from the Old Testament to the New Testament, we notice a steady falling off in hatred. In classical times, too, people hated strongly and well, and as every reader of Dante recognises- "Dante who loved well because he hated "- - there was little falling off in this emotion during what are called the Middle Ages. Indeed, the Italian genius for hatred is still maintained in the bitter local jealousies in neighbouring villages perhaps as well as anywhere else in the world; but readers of "Wuthering Heights" or of the "Green Graves of Balgowrie" will recognise that the existence of intense and local hatred is not confined to Italian villages.

Another example of hatred, concentrated, organised, official, religious hatred is the curse formally placed on Spinoza in 1656 in Holland, issued by the Jewish congregation and in the Portuguese tongue :

"With the judgment of the angels and of the saints we excommunicate, cut off, curse, and anathematise Baruch de Espinoza, with the con- 
sent of the elders and of all this holy congregation, in the presence of the holy books: by the 6I3 precepts which are written therein, with the anathema wherewith Joshua cursed Jericho, with the curse which Elisha laid upon the children, and with all the curses which are written in the law. Cursed be he by day and cursed be he by night. Cursed be he in sleeping and cursed be he in waking, cursed in going out and cursed in coming in. The Lord shall not pardon him, the wrath and fury of the Lord shall henceforth be kindled against this man, and shall lay upon him all the curses which are written in the book of the law. The Lord shall destroy his name under the sun, and cut him off for his undoing from all the tribes of Israel, with all the curses of the firmament which are written in the book of the law. But ye that cleave unto the Lord your God, live all of you this day."

The curse* recorded by Ernulphus (Bishop of Rochester, III4-II24) is even more comprehensive, but yet listen to what my uncle Toby said some centuries later about it :- “ 'I declare,'

* See Hearn's edition of the "Textus Roffensis" (Oxford: I720), p. 55 . 


\section{I2 STUDIES IN INSECT LIFE, ETC.}

quoth my uncle Toby, " my heart would not let me curse the devil himself with so much bitterness.' 'He is the father of curses,' replied Dr. Slop. 'So am not I,' replied my uncle. 'But he is cursed and damn'd already to all eternity,' replied Dr. Slop. 'I am sorry for it,' quoth my uncle Toby."

That on the whole hatred was until recently thought to be diminishing in quantity and perhaps in quality is shown by the fact that in "A New English Dictionary on Historical Principles," edited by Sir James Murray, and published at Oxford, Igor, hate is defined as " an emotion of extreme dislike or aversion; detestation, abhorrence, hatred. Now chiefly poet." This last fragment of a word-the italics are in the original -reminds one that in 1832 Shelley wrote "Why is it that we all write love-songs? Why shouldn't we write hate-songs?" and the Germans have recently written hate-songs, or at any rate revived them:

\footnotetext{
" un fiore

per l'amore,

o per odio una saetta."
}

CARDUCCI.

Nobody seems to have defined Hate very con- 
cisely. There are a whole series of emotions in which it has its origin and with which it is so bound up that it is very difficult to disentangle them. "You cannot unscramble an egg," as Mr. Pierpont Morgan assured us, and it is almost as difficult to disintegrate the divergent and at times discordant factors which end in hate. Could we do so we should find some factors temporary and others lasting.

If you stand on the bridge at Grantchester and watch the river tumbling "Under the mill, Under the mill," you notice ridges and swirls of water which appear permanent and have for a time an individuality of their own. They stand above the general level and race forward. But in the course of a few hundred yards these temporary entities have disappeared, and combined and fused into a placid, deep, and steady stream flowing irresistibly onwards. Thus it seems to be with hatred, composed of many strands, many apparently distinct streams, such as anger, fear, terror, despair, humiliation, dislike, indignation, contempt; many temporary, many passingone might almost enumerate the names of half Miss Flite's birds-yet all of these, for the most part, fleeting passions ultimately merge into a 
3 I4 STUDIES IN INSECT LIFE, ETC.

steady and persistent hatred which will seldom or never be appeased.

As Bain has pointed out, Hatred is an apparently permanent affection, grounded on anger and other emotions which in the main are transitory. Some wrong never mended, some standing attempt to harm another, are amongst the frequent causes which fan the flame of hate. To certain dispositions hatred is by no means unpleasant: in fact it becomes at times a pleasurable sensation; but to be a really satisfactory hater one must not only be irascible by nature, but be placed in some more or less frequent relationship with the object of the hatred. It is harder for a citizen of Southampton to hate a dweller in Saskatchewan or Saghalien than to hate a fellow-citizen who lives just round the corner. Rivalry, the forced submission to an unwelcome authority, unequal conditions of life perpetuate the emotions of hatred, which are often accentuated and fanned by party and sectarian feeling. Now, most people take a certain and often a deep interest in religious and social affairs, and the fact that different views on these ethical subjects engender and maintain hatred shows that to a certain extent the passion is a congenial one to 
man. An involuntary offence may cause anger which is quickly appeased by an adequate apology ; but when the involuntary offence is due to careless and complete disregard of the interest and feelings of others it is less easily put right, and the offended person feels himself less under an obligation to suppress his anger. The same also is true when the offender, well acquainted with our feelings of resentment and our consciousness of the harm, which we at any rate think, he is inflicting upon us, declines to alter a course of action tending to promote his own interest in entire disregard of our feelings or interest. And again, to quote Bain, "the fourth and highest species of wrong is the case of deliberate and intended offence. .. This opens before us such a state of mind, such a range of possible damage, that our angry senses are deeply moved, and call for vengeance."

We must not forget that hatred is by no means always or entirely a bad passion. Hatred of evil, hatred of wrong-doing may promote the progress of the world, but on the whole hatred is a passion which dulls the intellect and in the long run weakens the individual. Still there is such a thing as noble rage. 
At first sight one is rather inclined to associate hatred with want of education, and a general lack of cultivation, but in certain of its phases this is by no means true. Nothing is more astonishing than the bitterness that divergent political views produce. This is especially shown at times of "party" activity, such as a general election. The late Bishop Creighton wrote:

"I am convinced that every time the moral, and cultivated man exercises his right to vote, he seriously impairs his morality and his culture. The wrath one feels against opponents, the contempt for their intelligence, and the doubt about their honesty - this destroys that charity which is the highest aim of morality; while, on the other hand, the necessity of stating your views broadly, of making up your mind decidedly, of urging all kinds of argument on others which you only half believe, intellectually speaking, yourselfthis destroys true culture and robs it of half its bloom."

Since the beginning of the War I have met men whose reputations are world-wide, humane, kindly professors, who have probably never in their long lives killed anything more dangerous than a 
house-fly, men who have had reputations for fairness and justness which might have made them judges, yet they have stated that they would gladly assist in hanging a fellow-creature who owned certain newspapers, the views of which fail to accord with their own, and yet a man they had never met and could not have known. Religious hatred is equally bitter and equally to be regretted.

\section{" GR-R-R--there, go, my heart's abhorrence! Water your damned flower-pots, do! \\ If hate killed men, Brother Lawrence, God's blood, would not mine kill you ?"}

How far hatred is effective in war-time, and how far it can be effectively worked up by systematic effort, is difficult to say. I don't honestly think it can be effectively exploited with our British troops. An officer recently visited one of our trenches where some German prisoners were, and at an hour when a " sing-song " was in full swing was pleased to hear the Sergeant in the chair announcing "Item No. 4. Mister Fritz and Mister Moritz will now oblige with 'The 'ymn of 'ate." "

On the other hand, Le Bon felt that hatred played a very large part in the varying events 
3 I8 STUDIES IN INSECT LIFE, ETC.

of the French Revolution. The hatred of persons, of institutions or of things, was, at that epoch, by no means confined to the detestation of the mutually opposing parties. The leading men of the Revolution detested not only their enemies, but the members of their own party. During the last years of the eighteenth century there was a great outpouring of hate, especially in France. The leaders believed so implicitly in themselves that they could not tolerate the existence of others who differed but in a hair's breadth from their viws.

Commandant Colin, Professor at the College of War, states :

"In war more than at any other time there is no better inspiring force than hatred; it was hatred that made Blücher victorious over $\mathrm{Na}$ poleon. Analyse the most wonderful manœuvres, the most decisive operations, and if they are not the work of an exceptional man, a Frederick or a Napoleon, you will find they are inspired by passion more than by calculation. What would the war of 1870 have been without the hatred which we bore the Germans?"

We have but two comments on this quotation : 
(I) Wellington seems to have been overlooked.

(2) What was the war of 1870 even with the hatred the French bore the Germans!

Le Bon points out that Commandant Colin might have added that intense hatred of the Japanese for the Russians should be classed amongst the causes of their success. The tolerant and ignorant Russians, unaware for the most part even of the existence of the Japanese, felt no anger against them and thus fought with comparatively little enthusiasm. But the Russians, at any rate the Russians of this War, do know of the existence of the Germans.

Sooner or later hatred manifests itself in a state of rage, and in rage we find the symptoms of hatred, concentrated, condensed, and thus more easily analysed. I now propose to deal with the physiological conditions which accompany rage, and indeed perhaps produce this paroxysm, and I do not hesitate to begin by quoting Charles Darwin's classical description of this passion, which has never been equalled:

"Rage exhibits itself in the most diversified manner. The heart and circulation are always affected; the face reddens or becomes purple, 
320 STUDIES IN INSECT LIFE, ETC.

with the veins on the forehead and neck distended. The reddening of the skin has been observed with the copper-coloured Indians of South America, and even, as it is said, on the white cicatrices left by old wounds on negroes. Monkeys also redden from passion. With one of my own infants, under four months old, I repeatedly observed that the first symptom of an approaching passion was the rushing of the blood into his bare scalp. On the other hand, the action of the heart is sometimes so much impeded by great rage that the countenance becomes pallid or livid, and not a few men with heart-disease have dropped down dead under this powerful motion.

"The respiration is likewise affected; the chest heaves and the dilated nostrils quiver. As Tennyson writes, 'sharp breaths of anger puffed her fairy nostrils out.' Hence we have such expressions as 'breathing out vengeance,' ' fuming with anger.'

"The excited brain gives strength to the muscles, and at the same time energy to the will. The body is commonly held erect ready for instant action, but sometimes it is bent forward towards the offending person, with the limbs more or less 
rigid. The mouth is generally closed with firmness, showing fixed determination, and the teeth are clenched or ground together. Such gestures as the raising of the arms, with the fist clenched, as if to strike the offender, are common. Few men in a great passion, and telling someone to be gone, can resist acting as if they intended to strike or push the man violently away. The desire, indeed, to strike often becomes so intolerably strong that inanimate objects are struck or dashed to the ground; but gestures frequently become altogether purposeless or frantic. Young children, when in a violent rage, roll on the ground on their backs or bellies, screaming, kicking, scratching, or biting everything within reach. So it is, as I hear from Mr. Scott, with Hindoo children; and, as we have seen, with the young of the anthropomorphous apes.

"But the muscular system is often affected in a wholly different way; for trembling is a frequent consequence of extreme rage. The paralysed lips then refuse to obey the will, 'and the voice sticks in the throat,' or it is rendered loud, harsh, and discordant. If there be much and rapid speaking, the mouth froths. The hair sometimes bristles.... There is in most cases 
a strongly-marked frown on the forehead; for this follows from the sense of anything displeasing or difficult, together with concentration of mind. But sometimes the brow, instead of being much contracted and lowered, remains smooth, with the glaring eyes kept widely open. The eyes are always bright, or may, as Homer expresses it, be like a blazing fire. They are sometimes bloodshot, and are said to protrude from their socketsthe result, no doubt, of the head being gorged with blood, as shown by the veins being distended. According to Gratiolet, the pupils are always contracted in rage, and I hear from Dr. CrichtonBrowne that this is the case in the fierce delirium of meningitis; but the movements of the iris under the influence of the different emotions is a very obscure subject."

Tasso thus describes the rage of Argante:

"Tacque; e'l Pagano, al sofferir poco uso, Morde le labbra, e di furor si strugge.

Risponder vuol, ma 'l suono esçe confuso,

Si come strido d' animal che rugge:

O come apre le nubi, ond' egli è chiuso, Impetuoso il fulmine, e sen fugge; Così pareva a forza ogni suo detto Tonando uscir dall' infiammato petto."

Cant. vi. 38 .

and Ariosto tells : 
"Trema 'l cor dentro, e treman fuor la labbia, Non può la lingua disnodar parola, La bocca ha amara e par che tosco v' habbia." Orl. Fur. xlii. 4I.

and again :

“E per l' ossa un tremor freddo gli scorre, ... Con cor trafitto, e con pallida faccia, $\mathrm{E}$ con voce tremante, e bocca amara."

Orl. Fur. v. 40, 4I.

The description of the Fifth Circle of Dante's Hell deals with Iracondi, " the souls of those whom anger overcame."

In Purgatory again, in the Third Circle, those who expiate the sin of wrath are wrapped around in a dim, pungent smoke, which recalls the German gases ; this, as Professor Toynbee says, "blinds them as they had been blinded on earth by their angry passions." There were no gas-masks in Dante's Purgatory.

Finally, William James, in his "Principles of Psychology," quotes the following description of hatred from Mantegazza:

"Withdrawal of the head backwards, withdrawal of the trunk; projection forwards of the hands, as if to defend one's self against the hated object ; contraction or closure of the eyes ; elevation of the upper lip and closure of the nose,- 


\section{STUDIES IN INSECT LIFE, ETC.}

these are elementary movements of turning away. Next threatening movements, as : intense frowning ; eyes wide open ; display of teeth ; grinding teeth and contracting jaws; opened mouth vith tongue advanced; clenched fists; threatening action of arms; stamping with the feet; deep inspirations-panting; growling and various cries ; automatic repetition of one word or syllable; sudden weakness and trembling of voice ; spitting. Finally, various miscellaneous reactions and vasomotor symptoms ; general trembling, convulsions of lips and facial muscles, of limbs and of trunk ; acts of violence to one's self, as biting fist or nails ; sardonic laughter ; bright redness of face ; sudden pallor of face; extreme dilatation of nostrils ; standing up of hair on head."

James considers, in his chapter on Emotions, the reactions which are characteristics of but three sets of feeling-grief, fear, and hatred. Whilst declining to enlarge his list, he points out that should he do so he would but ring the changes on the physiological elements with which these three typical cases are involved, the rigidity of certain muscles, relaxation of others, constrictions of some arteries, loosening of others, variations 
and irregularities of the respiration, increasing or lowering of the pulse-beat, certain glands secreting whilst others dry up. Thus he generalises on the more special and detailed records of Darwin and Mantagazza.

Before leaving a description of the human face animated by Hatred, we must not omit to draw attention to the researches of the brilliant Canadian sculptor, Tait Mackenzie, now Professor of Physical Culture at the University of Pennsylvania. $\mathrm{He}$ had made a profound study of the expression of the emotions in violent exercise, partly from photographs, but largely by personal observation. His skill as a sculptor has enabled him to prepare a series of masks of the face showing the various stages of exhaustion or fatigue which accompany violent physical exercise. We need only deal with one such mask, that of a competitor, just at the finish of what in America is called " a hundred yards dash." If we study a mask of some student who is just at the end of a "dash" we shall find that in his face there is a general convergence of the lines to the root of the nose, the frowning brows are drawn down and the eyes closed to the merest slits. The crow's feet at the outer angle of the eye are developed to a degree quite 


\section{STUDIES IN INSECT LIFE, ETC.}

unknown at that age under ordinary circumstances in any student. The sneering expression of the nose is like the snarl of a dog, whilst the angles of the upper lip are drawn up so as to expose the canine teeth; the nose is dilated, the upper lip raised from the teeth, whilst the lower lip is drawn tightly across the clenched teeth, except at the outer angles. As Tait Mackenzie says: " the general expression of the face is repulsive. Hate and rage predominate, with a feeling of distress about the strained mouth and neck."

This realistic mask corresponds very accurately with the classical drawing of "Rage" in Sir Charles Bell's work entitled "The Anatomy and Philosophy of Expression," except for the fact that in Sir Charles' figure the eyes are open and somewhat staring. At any rate there can be no doubt that the facial expression of hate and of extreme physical effort closely correspond, and we shall see later that the physiological processes which produce such similar expressions are in themselves identical.

Every now and then hate boils up into rage ; and we now turn to the physiological effect according to one school, or to the physiological 
cause according to another, of hatred as manifested in rage.

Just above the kidneys there are two small glands, each about as big as a pea, known as suprarenal capsules, or adrenal glands. They. belong to that small group of glands in our bodies which have no ducts, and whose secretions, whatever they are, pass directly into the blood. I have often wondered whether the ancient Hebrews knew anything about their effect, because they were so very particular in their burnt offerings to offer up "the fat upon the kidneys."* At any rate these two little glands play an enormous part in the physiology of hate. The secretion that these bodies pour into the blood is known as adrenalin. It is not controlled by the will. We cannot by taking thought diminish or increase the secretion of adrenalin. This secretion is of the nature of what physiologists call a "reflex," and its reaction is deeply entangled in the working of the nervous system, and is indeed automatic. It has for a long time been recognised that the characteristic feature of reflexes is purposeful: i.e., they automatically serve some object useful

* See "The Religion of the Semites," by W. Robertson Smith, p. 379. 
to the individual, and so to the race. When they act they are acting in the interest of the body. Such reflexes as sucking, vomiting, coughing (and many others might be mentioned) are all helpful to the individual and ultimately to the race. So that when we find automatic reflexes accompanying pain, fear, and rage, it is not unnatural to ask, What is their utility? Here we may mention that the results of increased secretion on the part of the adrenal bodies are practically the same as the result of the injection of adrenalin into the body. We have already seen that when a man turns into a violent rage his tendency is at once to combat or fight those against whom his rage is directed. Hence, whatever reactions may be useful, they must at least be prompt. As Professor Cannon and his able assistants have shown in their book on "Bodily Changes in Pain, Hunger, Fear and Rage," the effect of the adrenalin secretion is manifest in sixteen seconds, whilst the amount of sugar in the blood will in the course of "a few minutes" rise between Io and 30 per cent.

For one of the first effects of an increase in this secretion is a pronounced increase of sugar in the blood. Now, muscular work is performed by 
energies supplied by carbonaceous material, and this sudden accession of sugar in the blood supplies the muscles with a much-needed food. "In the agony of pain almost every muscle of the body is brought into strong reaction," as Darwin wrote, and there is a considerable amount of evidence that the increase of sugar in the blood does, as Cannon says, in fact directly increase the muscular efficiency. Thus one of the effects of the secretion of adrenalin would be of direct benefit to an organism in a rage wishing to exercise stern muscular effort involving flight, conflict, or a struggle to be free.

Then, again, as Cannon points out, there is evidence that an increased secretion of adrenalin restore; the irritability of fatigued muscle. The rem jval of the adrenal glands has a weakening effect on muscular power, and the injection of adrenalin has an invigorating effect. So that not only does adrenalin bring out sugar from the liver-stock to feed the muscles, but it also has a remarkable influence in restoring fatigued muscles, and thus the secretion set free in pain or fear or rage puts the muscles of the body at the disposal of the nervous system, and any difficulty which the nerve impulses might have had in calling the 
muscles into full activity is diminished or done away with.

Thirdly, the flow of adrenalin has marked effects on the vascular system, and all of these effects are helpful or advantageous to men in a condition of rage or fear. Its sudden presence in the blood drives the blood from the abdominal viscera into the organs which are most wanted for active combat: into "the central nervous system, the lungs, the heart, and the active skeletal muscles." Again, in small quantities the secretion has a stimulating effect upon the heart, and so it comes about that when a greater amount of work is demanded from the heart, with increased arterial pressure, blood is delivered to the heart in greater abundance, and the augmentation of the heartbeat is thus co-ordinated with other functions adapted to meet great emergencies.

Then again numerous investigators have shown that the injection of adrenalin into the blood produces a dilatation of the bronchioles, or ultimate passages of the lungs. The smooth muscles of the lungs are relaxed and deep, and rapid respiration, which is characteristic of all animals in pain or in great emotional excitement, is rendered more easy. 
Finally, an animal which is to conquer in an imminent combat, should he be wounded, would obviously be advantaged if his blood clots quickly and well. Now, pain increases the adrenalin secretion, and, according to Cannon and his colleagues, it also hastens the coagulation of the blood. Thus even a wound may have alleviating aspects. It increases the adrenalin secretion (which may help to close the cut vessels of the wound itself), and it hastens clotting of the blood.

We have thus seen that the secretion of these two inconspicuous little glands, which until recently have been regarded as a small matter, plays a very large part in the bodily changes which occur in states of extreme pain, fear, or rage, and serve to place "un enragé" in an eminently favourable state for wreaking his passion on his opponent.

We have also shown that extreme rage and extreme physical effort produce on the face expressions that are almost identical. Now, it cannot be pretended for a moment that men at the end of a "sprint" are in a state of hatred. Hence it seems to follow that men in a state of hatred are in the same condition as men who 


\section{STUDIES IN INSECT LIFE, ETC.}

are putting out their utmost physical effort: that is to say, they are in a condition, should they come across the object of their hate, to exert the maximum harm upon it. 


\section{INDEX}

"Accedens of Armory," 232.

"Albumazar," 307.

"Alchemist," 307.

Aldrovandi, Ulisse, 254.

Allman, Professor, r57, r69, I80.

Annelida, 256.

Anobium paniceum, $35 ; A$. Striatum, 35.

Anopheles maeulipenns, 25, 28. Anoplura, ro.

Apis mellifica (honey-bee), 37 , $70,73,80,82,83,259$.

Appendicularia, Ir3.

Ariosto, 322.

Ashmole, E., 256.

Atlantic Ocean, depth of, 96, I74.

Auchmeromyia luteola, 28.

Aulostoma, 256.

Bacillus coli, 19r, 215, 217.

Bacon, Francis, 269, 270.

Bacon, Roger, 226.

Bain, on Hate, 314, 315.

Baird, on Grouse tape-worms, 203.

Balaena, II5.

Banks, Sir Joseph, 292 note.

Bartholomaeus Anglicus, 225.

Bell, Sir Charles, 326.
Benthos, II3, I20.

Blue-bottle, 28.

Board of Agriculture and Fisheries, 151, 158, 159, I64.

Bombus (humble-bee), 68, 69, 80,83 ; B. terrestris, $7 \mathrm{I}$, $78,80,83$; B. lapidarius, $7 \mathrm{I}, \quad 72, \quad 78, \quad 79 ; \quad B$. lucorum, 78 .

Boyle, Robert, 301, 302.

Brandt, Professor, 140, 154 .

Brocke, Ten B., 255.

Brown, Crum, r8o.

Browne, Dr. Crichton, 322.

Browne, Sir Thomas, 282.

British Association, I2r.

Bruce, 96.

Bubonic plague, 20, 2r, 306.

"Bulldog," H.M.S., r68.

Burton, Robert (quoted), 283.

Butler, Samuel, 307.

Cannon, Professor, on Hate, $328,329,33$ r.

Carducci (quoted), 312.

Caird, J., I28.

Caius, John, 229, 236, 255.

Calzolari, F., 255.

Carder bees, 73 .

Cavendish's thermometer, 167 . 
Cephalopods, III, 257.

Ceratophyllus fasciatus, 20.

"Challenger," H.M.S., II6, I69, I70, I8I, I84, I87.

Charles II., 285, 286.

Cherbury, Lord Herbert of, 23I, 27I, 273, 274.

Chigo (burrowing-flea), Ig.

Cimex lectularius (bed-bug), I0, I3, I4.

Clerk Maxwell, I8o.

Cobbold, on Parasites, 212.

Coccidiosis, I94, 205, 206, 207. 208, 210, 219.

Coccidium, 206, 207, 208, 209, 2IO, 2 Ig.

Coccolithophoridæ, II6, II7, II 8 , II9.

Coccus, 206.

Colin, Commandant, Hatred, 3 I8.

Continental shelf, 95, I74;C. slope, 95.

Commission of Fish and Fisheries (U.S.), I53, $155-6$.

Convoluta, I22.

Cowley, A. (quoted), 294, 304, 305.

Crawford, Donald, 127.

Creighton, Bishop (quoted), 3 I6.

Crustacea, 92, I04, II2, II5, 257.

Ctenocephalus felis, 20 ; Ct. canis, 20.

Culex, 28.

Current-meter, Ekman's, IIo. Cyclothone, III.
Dannevig, Captain, I38.

Dante, 27I, 310, 323.

Darwin, I7I, 319-22, 329.

Davainea urogalli, 201, 202, 203.

"De Differentiis Animalium," 235.

De Geer, $\mathbf{I 7}$.

"De Tradendis Disciplinis," 226.

"The Depths of the Ocean," I 86.

Diatomes, I00, I0I, II8, I78. Digby, Sir K., 277, 287.

" Display of Heraldry," 232. Donne, John, 305, 306.

Edinburgh Evening Club, I8I. Eimeria avium, 206, 207, 211 .

Empusa, 32.

Ent, Sir George, 280, 297.

Ephestia kuhniella, 33, 34; E. cautella, 35 .

"Epicoene (Silent Woman)," 284.

Ernulphus (curse of), 3 II.

Euglossa, 84.

Evans, 234.

Evelyn, John, 275, 277, 278, $287,288,304$.

Ewart, Professor Cossar, I57.

Fantham, Dr., 8, I8, 208.

"Fauna and Flora of Liverpool Bay," I62.

Ferdinand II. (Archduke), 255.

Fleas, I8-9. 


\section{INDEX}

Fleming, Abraham, 236.

Foll, Hermann, I04.

Foraminifera, 98, 99, ror, ro7.

Foster, Sir Michael, 296 note.

Franchini, Dr., I7.

Fulton, Dr., I34.

Galileo, 268, 286.

Gamble and Keble, I23.

Gauss expedition, I54.

Gesner, Conrad, 23I, 234, $236,237,238$.

Gilbert, W., 267.

Glisson, F., 288, 297.

Globigerina, 99, Iоo, Iог, I78.

Goodsir, I57, I80.

Gran, Dr., II5, II6, II7, II8.

Green, Rev. S., I58.

Grew, N., 298.

Grouse Disease Inquiry, I9I, I92, I93, I94, 20 I.

Gunter, E., 267.

Harting, H., 24I, 243, 246, $247,248$.

Harvey, Baldwin(quoted), 295 . Harvey, W., 228, 270, 293 , 294, 295, 297, 302.

Heincke, Dr., I54.

Helland-Hansen, Dr., I03, IIo, II9.

Hensen, Professor, I40, I54. Herdman, Professor, I62.

"Historia Animalium" (Gesner), 237.

"History of Foure-footed Beasts and Serpents," $230,237,238$.
Hjort, Dr. Johan, II2, I86.

Hobbes, 28I, 290.

Holland, Philemon, 236.

Holt, E. W. L., I58.

House-fly, 28, 29, 3I-3.

Huxley, Professor, I28, I29, I30, I34, 272.

" Huxley," r48.

Hymenolepis, 204, 216; $H$. microps, 204, 205; $H$. diminuta, 205.

International Investigation of the North Sea, I42, I64.

" Insectorum sive Minimorum Animalium Theatrum," 230.

Irish Fishery Board, II2, I57, I58.

Jackson, Sir John, I8I.

James I., 28I, 282.

James, William, 323, 324 .

Jenkin, Fleeming, I69.

Jenkins, Dr., I63.

Johnstone, Mr., I2I, I22, I63.

Jonson, Ben, 283, 284, 307.

Kala-azar (black fever), I7.

Kelvin, Lord, I80.

Kiel Kommission, I53.

Klein, I90, I9I.

Krümmel, Professor, I54.

Laminaria, 92.

Larvæ of $P$. vestimenti, 6-8 ; fleas, 23 ; flies, 30 ; bees, 50-I, 76-8; Lepidoptera, 258 . 
Latter, 39, 62.

Laveran, Professor, 17.

Le Bon, 3r7, 3r9.

Legh, Gerard, 232.

Leiper, Dr., 205.

Leptocephalus (larva of eel), I08, II2.

"Liber de Proprietatibus Rerum," 225.

"Life in the Sea," I2r.

Limax, 203.

Liverpool Marine Biological Committee, $\mathrm{r} 62$.

Lohmann, II8, Ir9.

Mackay, Æ., r83.

Mackenzie, Tait, 325, 326.

Maeterlinck (quoted), 4I note, 66,24 I.

Malaria, 24, 25.

Malpighi, 293, 298.

Marine Biological Associa-

tion, I25 note, I42, I43,

I44, I59 note, I63, I65.

Mayerne, Sir Theodore T. de,

295.

Mayow, John, 277, 296.

McIntosh, Professor W. C., Pacific Ocean, depth of, 95, I57.

McLennan, J. F., I82.

Medici, 285, 286.

Meik, I8r.

Melanocetus, IrI.

Miall, Professor (quoted), 300.

" Michael Sars," 90, 9r, ro3,

Iro, II2, Ir5, 186 .

"Micrographia," 280.

Milton, 23I, 27I, 272, 273.
Minchin, Professor, 205.

Moffett, Thomas, 229, 230.

Moore, Dr. Norman, 295 note.

Mosquitos, 24, 26.

Mulgrave's (Lord) Expedition, 167 .

Murray, Andrew, 3.

Murray, Sir John, 94, rr6, I57, I66, I69, I70, I7I, I72, I74, I77, I78, I79, 187.

Musca domestica, diseases caused by, 33 .

Napier of Merchiston, 267.

Nectar, 57-9.

Nekton, 120.

Newton, Sir Isaac, 272, 289, 29r, 292, 302.

Nicol, Sergeant D., 33.

Nicoll, 205.

Ornithomyia avicularia, I99; O. lagopodis, I99.

"Oithona," I48.

I74.

Pattison, Mark, 272 note.

Pecten, 257.

Pediculus capitis, 2, 4, 9; $P$. vestimentis, $2,4,6,9$.

Penny, Thomas, 230, 231.

Pepys, S., I20, 268, 278, 280, 285 and note.

Peridineæ, II8.

Photometer experiments, I03. 
"Physiologus Theobaldi Salmon Fishery Act, I58.

Episcopi de naturis Sars, Professor G. O., I29.

duodecim aialium," 223. Schimper, Dr., II8.

" Planet," I74.

Plankton, II3, II4, II5, II9, I20; Plankton Expedition, I54.

Plater, Felix, 239, 255.

Pliny, 226, 227, 249, 25I.

Plunkett, Sir Horace, I58.

"Pomerania" expedition, I54.

Pontosphara huxleyi, II7.

Porter, Dr., I8.

"Principia," 292.

Pteropods, I0o, I78.

Pulex irritans, I9, 23.

Pullar, F., I87 ; Pullar, L.,I87.

Quick Laboratory, 3, 8.

Radiolaria, I00, I0I, I77.

Ray, John, 256; 299, 300.

Red clay, I00, I77.

Robertson-Smith, W., I8o, I8I, 327 note.

Ross, James, I67.

Ross, Sir John, I68.

Rothschild, Hon. Charles, 20.

Royal Commission on Fisheries, I28, I34.

Royal Society, 280, 303, 305 , 307.

Runciman, I59 note.

Rupert, Prince, 286, 287.

Russell, Harold, I9, 2 I.

Sagitta, II4.
Schmidt, Dr., Ir2.

"Science of the Sea," Ir6.

Scottish Fishery Board, I34, I37, I57, I64.

Sea-fisheries Act, I3r.

Sharp, Dr., I99.

Shaw Lefevre, G., I28.

Siegen, Ludwig von, 287.

Sladen, Mr., 70.

Smith, Dr. Graham, 214.

Somerset, E., 287.

"Speculum naturale," 224.

Spinoza, 3 ro.

Spirillosis, I98.

Spirochaeta recurrentis (of relapsing fever), 9, ro.

Spirula, III.

Stadler, Dr. H., 48, 59.

Stegomyia calopus, 25, 27.

Stevenson, R. L., r8r.

Strongylosis, I94, 2I2, 2I9, 220.

"Structure of the Human Body," 229.

Sydenham, Thomas, 296, 297.

"Sylva," 278.

Tasso, 322.

Tait, Professor, I80, I84.

Thompson, Professor D'Arcy, I58.

Topsell, Edward, 230, 237. 238, 250.

Thomson, Wyville, $184, \mathbf{r} 85$.

Tradescant, 256. 
Trawling Commission, 136 . Vincent of Beauvais, 224 . Trichosoma longicolle, 205. Virgil, 46, 59, 226, 232. Trichostrongylus pergracilis, Vives, 226, 227, 232. 204, 212, 214, 2I5, 216. Tsetse-fly, 28, I99.

Wallich, Dr., 168.

Turner, William, 233, 234, Wallis, John, 288, 289. 235.

Warburton, C., 3, 4, 7 .

Typhus, carried by $P$. vestimenti, 9, I0.

Urodela, 26r.

Ward, Seth, 289, 290, 29I, 302.

Weevil, 35.

Willughby, F., 299, 300.

Wotton, Edward, 23I, 235.

"Valdivia," II8, I54.

Vesalius, 228, 229, 266.

Vespa, 70, 83 .

Xenopsylla cheopis, 20.

Zostera, 94. 
$q$ - terathyolus:

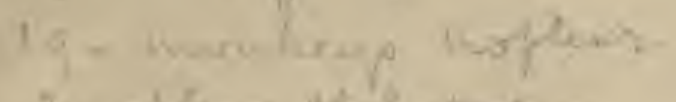

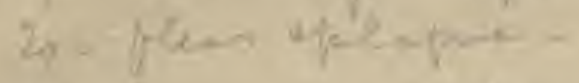

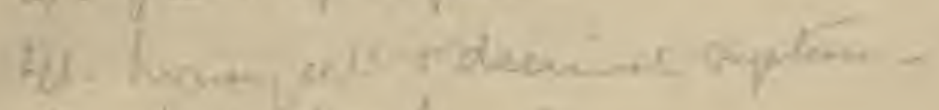

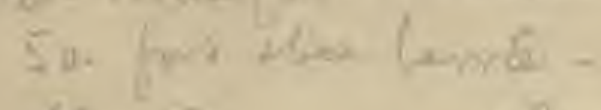

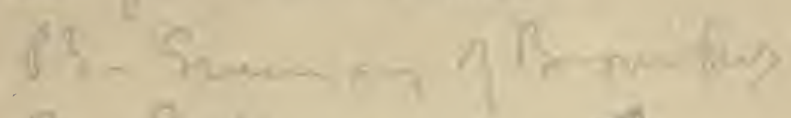

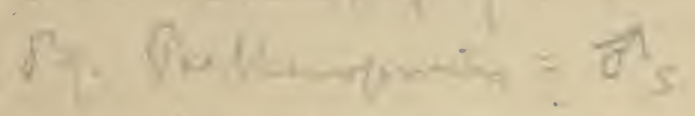

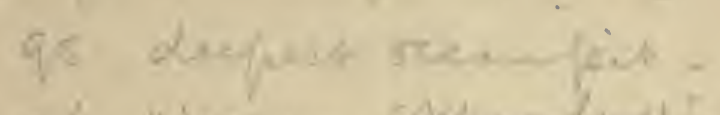

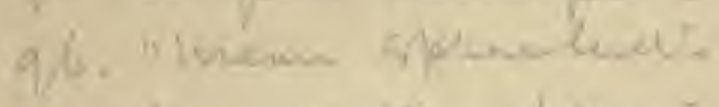

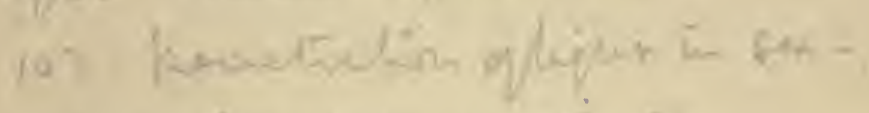

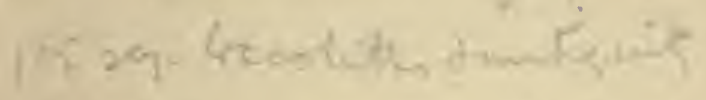

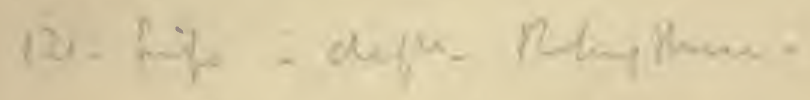

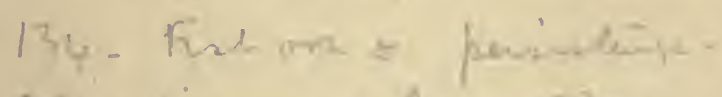

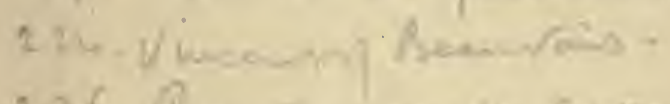

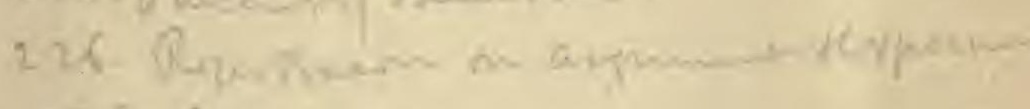

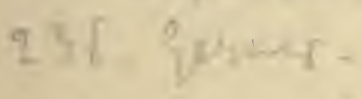

25. Howe-leceh-

$26 \%$ alc $-1, x$

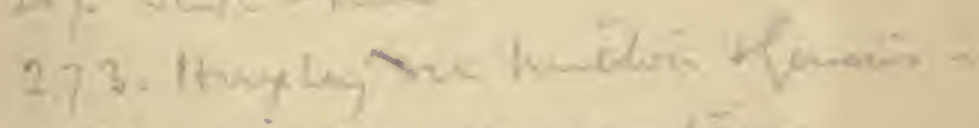

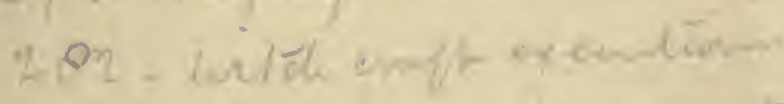

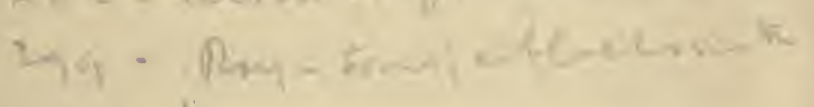
327.1

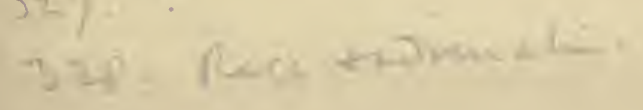




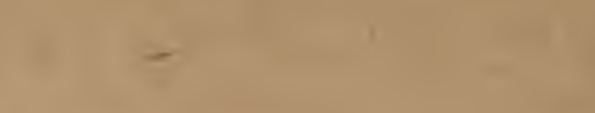

9

$-5$

+

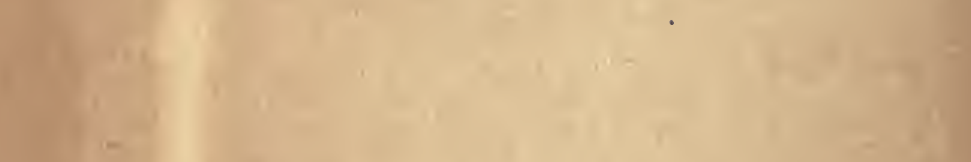

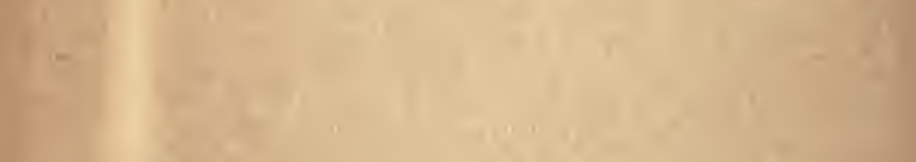

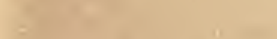

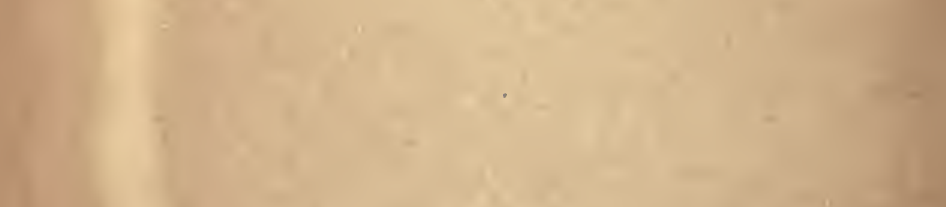

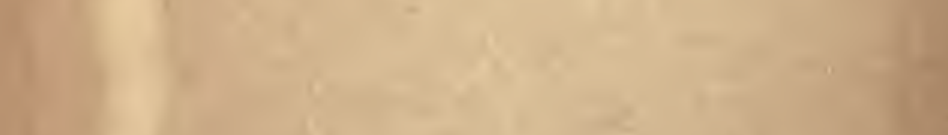
10.

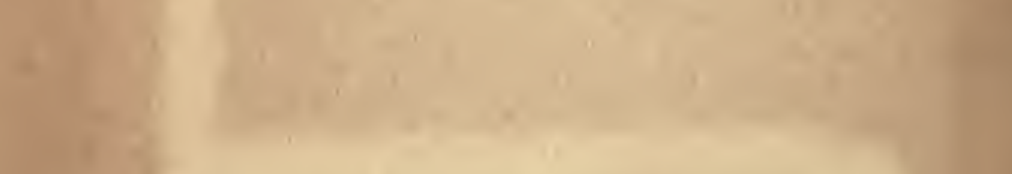

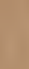

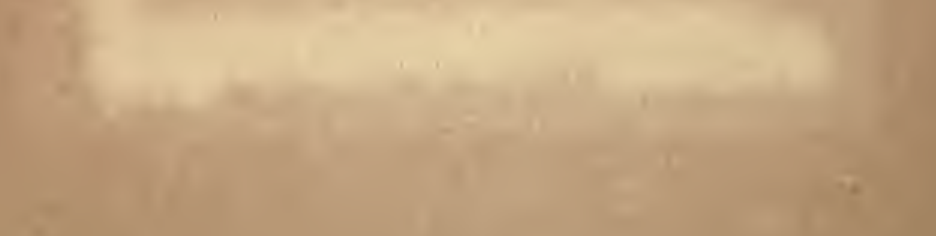





$$
\text { AEL'S }
$$

(2) 
SHIPLEY, A.E.

Studies in insect life.

QI.

463

.55 
